\title{
Proteome-wide Identification of New Molecular Targets Affected by Methotrexate in Acute Promyelocytic Leukaemia Cell Line
}

\author{
Dissertation \\ zur Erlangung des Doktorgrades \\ der Mathematisch-Naturwissenschaftlichen Fakultäten \\ der Georg-August-Universität zu Göttingen
}

vorgelegt von

Nitin Kumar Agarwal

aus Bareilly, Uttar Pradesh, India

Göttingen 2007 
D7

Referent: Prof. Dr. R. Hardeland

Korreferent: Prof. Dr. D. Doenecke

Tag der mündlichen Prüfung: May 02, 2007 


\title{
Proteome-wide Identification of New Molecular Targets \\ Affected by Methotrexate in Acute Promyelocytic
}

Leukaemia Cell Line

\author{
Nitin Kumar Agarwal \\ Georg-August-Universität zu Göttingen, 2007
}

\begin{abstract}
Methotrexate (MTX) was first introduced as a cytotoxic agent that inhibits nucleotide biosynthesis in various cancer disorders. Accumulating evidences suggest that MTX inhibits the proliferation of malignant cells by inhibiting 5-aminoimidazole-4-carboxamide ribonucleotide transformylase, isoprenylcysteine carboxyl methyltransferase and NF- $\kappa \mathrm{B}$ transcription factor. These observations indicate that MTX could have additional molecular targets that are therefore unappreciated. To get insights into the complex molecular mechanisms of MTX induced apoptosis in acute promyelocytic leukemia cells (HL-60), we conducted an investigation incorporating cysteine labeled differential in-gel electrophoresis combined with mass spectrometry. Initial experimental analysis revealed that 24 proteins were differentially expressed $(p<0.05)$ in HL-60 cell proteome after addition of $2.5 \mu \mathrm{M}$ MTX for $72 \mathrm{~h}$. The majority of MTX induced proteins were ascribed to the endoplasmic reticulum (ER) chaperones, glycolytic enzymes and the mitochondrial transmembrane electron transport system (MTETS). In particular, we noted that three structural $\alpha 4, \alpha 5, \alpha 7$; a non-catalytically $\beta 3$ and two $26 \mathrm{~S}$ regulatory proteasome subunits were significantly down regulated in MTX treated HL-60 cell. We further showed in
\end{abstract}


HL-60 cells that MTX induces ER chaperones, suppresses the NF- $\kappa$ B subunit p65, disturbs the mitochondrial transmembrane potential $\left(\Delta \psi_{\mathrm{m}}\right)$ and generates reactive oxygen species (ROS) in a time-dependent manner. All together, our findings revealed that MTX alter the level of a variety of proteins involved in the NF- $\kappa \mathrm{B}$ associated proteasome complex formation, ER stress, and the MTETS. Their identification as molecular targets of MTX may provide new impulse in the understanding of apoptotic activities in acute promyelocytic leukaemia cell line. 


\section{TABLE OF CONTENTS}

1 INTRODUCTION 1

1.1 THE MOLECULAR BASIS OF LEUKAEMIAS .......................................... 1

1.1.1 Differentiation blockade: The role of transcription factors in APL ............ 2

1.1.2 Core binding factors in APL ............................................................... 2

1.1.3 Molecular deregulation of receptor tyrosine kinases in APL ...................... 3

1.1.4 The BCR-ABL fusion gene and leukaemia ............................................ 4

1.1.5 Activated mutation in Fms-like tyrosine kinase-3 receptor........................ 4

1.1.6 Inappropriate proliferation: The role of signalling molecules.................... 5

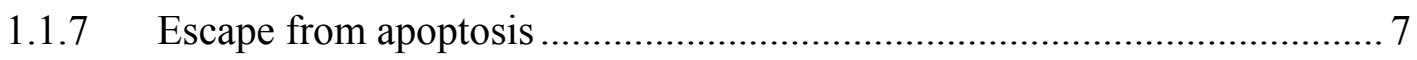

1.2 CURRENT THERAPIES AND FUTURE DIRECTIONS................................. 7

1.3 ANTI-METABOLITES (FOLIC ACID ANALOGUES) .................................. 8

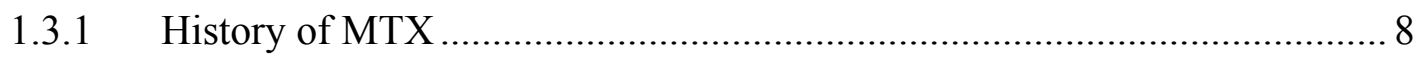

1.3.2 Chemistry and metabolic activities of folates.......................................... 9

1.3.3 Mechanism of action of MTX ….................................................................. 12

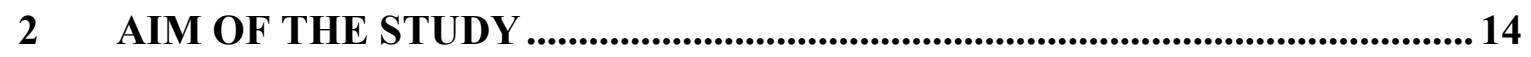

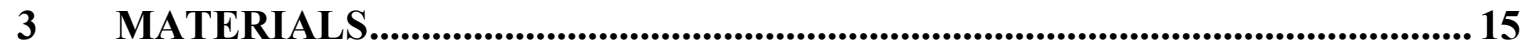

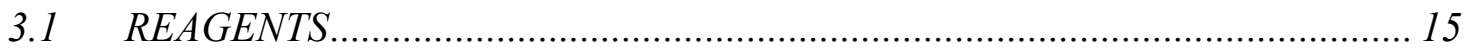

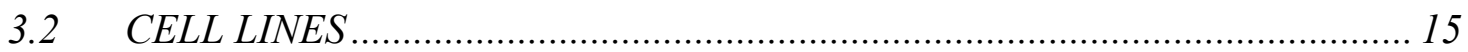

3.2.1 HL-60 cell line (Human promyelocytic leukaemia cell) ......................... 15

3.2.2 A498 cell line (Renal epithelial carcinoma cell) ................................... 16

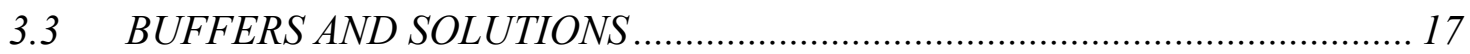

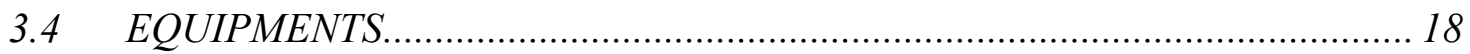

3.5 SCIENTIFIC ONLINE SEQUENCES AND SOFTWARE SERVICES............... 19

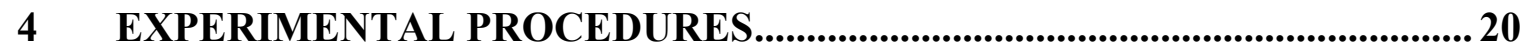

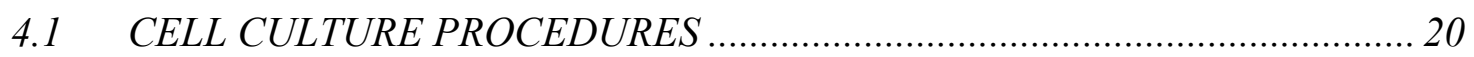

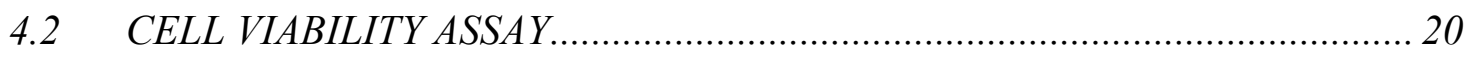

4.3 DETECTION OF PHOSPHATIDYLSERINE BY ANNEXIN-V ....................... 20 
4.4 CELL LYSATE PREPARATION FOR TWO DIMENSIONAL GEL

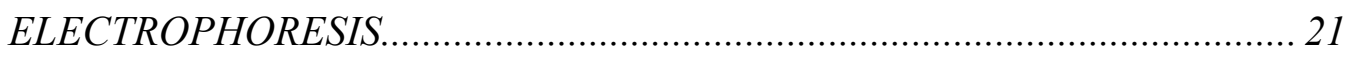

4.5 PROTEIN PRECIPITATION AND ESTIMATION …....................................... 21

4.6 PROTEIN CYDYES SATURATION LABELLING ........................................ 22

4.7 TWO DIMENSIONAL GEL ELECTROPHORESIS ........................................ 25

4.8 PROTEIN VISUALIZATION AND IMAGE ANALYSIS .................................. 26

4.9 IN-GEL DIGESTION AND MALDI-TOF MS ANALYSIS OF PROTEIN SPOTS 27

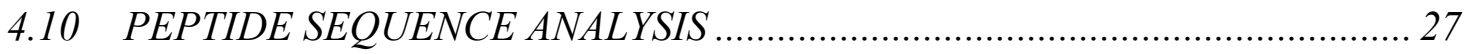

4.11 DATABASE SEARCH AND PROTEIN IDENTIFICATION ........................... 28

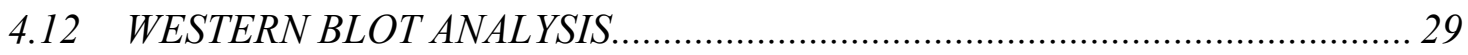

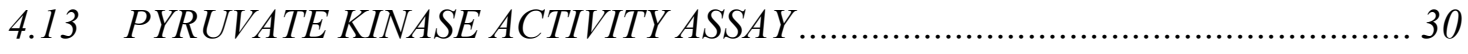

4.14 ANALYSIS OF MITOCHONDRIA MEMBRANES POTENTIAL .................... 30

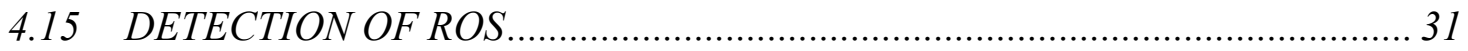

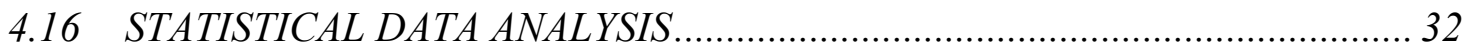

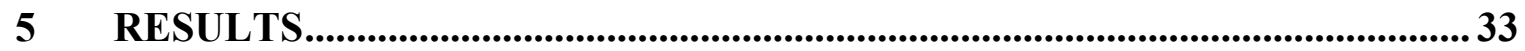

5.1 MTX DEMONSTRATES CELL TOXICITY ON HL-60 CELLS....................... 33

5.2 MTX INDUCES APOPTOSIS IN HL-60 AND A498 CELLS ........................... 34

5.3 EVALUATING EXPERIMENTAL REPRODUCIBILITY OF THE CYSTEINE LABELLED IN-GEL ELECTROPHORESIS APPROACH............................ 39

5.4 IDENTIFICATION OF DIFFERENTIALLY EXPRESSED PROTEINS IN MTX

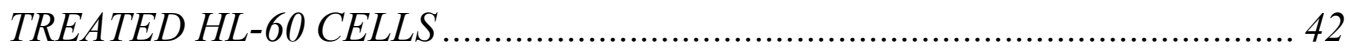

5.4.1 MTX down regulates proteasome subunits in HL-60 cells ....................... 48

5.4.2 Differential effect of MTX on glycolytic and MTETS pathways ............. 51

5.5 MTX INDUCES ER STRESS IS LINKED TO ALTERATION IN THE PROTEASOME PROTEIN EXPRESSION ……............................................ 54

5.6 MTX ALTERS MITOCHONDRIAL MEMBRANE POTENTIAL AND

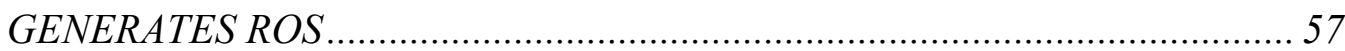


6 DISCUSSION

6.1 SEQUENTIAL EVENTS OF APOPTOSIS INDUCED IN MTX TREATED

CANCER CELLS

6.2 MOLECULAR TARGETS AND PATHWAYS INVOLVED IN CELL RESPONSE TO MTX.

6.2.1 MTX induced inhibition of NF- $\mathrm{kB}$ subunit $\mathrm{p} 65$ and proteasome subunits correlate with the induction of ER chaperones

6.2.2 MTX induced MTETS proteins impairment reveal glycolysis involvement 66

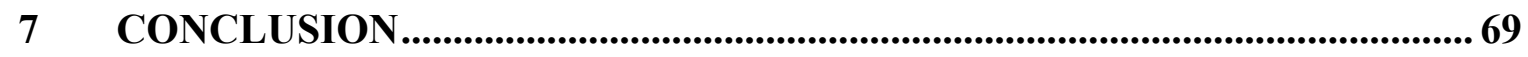

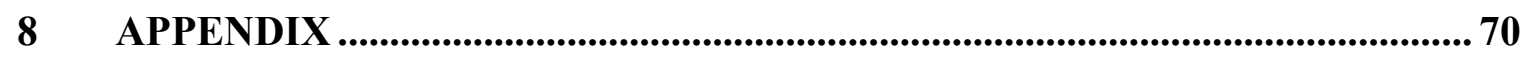

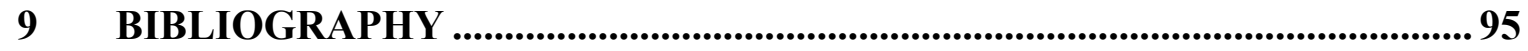

10 ACKNOWLEDGEMENT ........................................................................................ 107 


\section{LIST OF FIGURES}

Figure 1. The chemical structure of pteroylglutamic acid (folic acid) ........................... 9

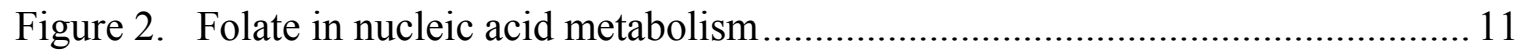

Figure 3. Sites of action of MTX and MTX polyglutamates........................................ 13

Figure 4. Schematic diagram of labelling reaction of protein thiols with maleimide CyDyes 23

Figure 5. Workflow for cysteine labelled differential in-gel electrophoresis analysis.... 24

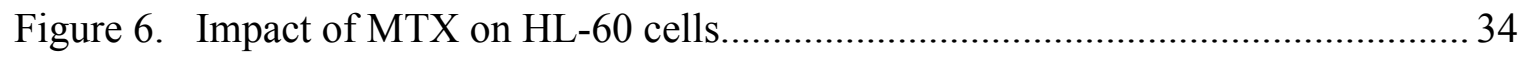

Figure 7. Morphological changes observed in HL-60 cells after MTX treatment .......... 35

Figure 8. Assessment of apoptosis by FITC-labelled-annexin-V staining assay ............ 37

Figure 9. Morphological events of apoptosis examined by flow cytometry ................... 38

Figure 10. Partial view of two-dimensional gel electrophoresis; gels obtained from MTX treated HL-60 cell lysates visualised by silver stain or Cy5 dye.................... 40

Figure 11. Evaluation of experimental reproducibility by Scatter Plot analysis .............. 41

Figure 12. Large dual colour two-dimensional image of proteins expression profile obtained from untreated and MTX treated HL-60 cell lysates labelled with

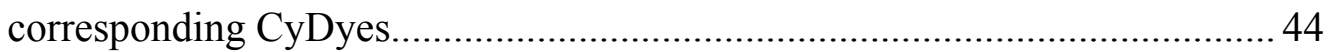

Figure 13. Down regulation of six proteasome subunits in MTX treated HL-60 cells .... 50

Figure 14. MTX induces pyruvate kinase activity and increases the expression of triosephosphate isomerase (TPI) in HL-60 and A498 cancer cells

Figure 15. Differential expression of mitochondrial proteins in MTX treated HL-60 cell line

Figure 16. Western blot analyses of ER chaperones and NF- $\kappa \mathrm{B}$ affected by MTX in HL-60 and A498 cancer cells

Figure 17 MTX induces apoptosis is associated with altered mitochondrial membrane potential 58

Figure 18. Induction of ROS formation in MTX treated A498 cells. 60 


\section{LIST OF TABLES}

Table 1. Multisteps protocol for isoelectric focusing of IPG strips............................... 25

Table 2. Excitation and emission wavelengths used for imaging of fluorochrome labelled

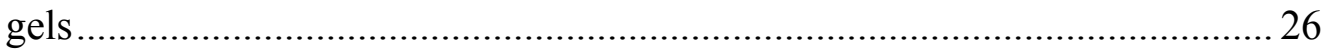

Table 3. Summary of untreated and MTX treated HL-60 proteome analysed by Delta 2D software

Table 4. List of the proteins that were differentially expressed in HL-60 cells during treatment with $2.5 \mu \mathrm{M}$ MTX for 72 hours 46

Table 5. Over expression of glycolytic enzymes in MTX treated HL-60 cells 51 


\section{LIST OF ABBREVIATIONS}

\begin{tabular}{|c|c|}
\hline Abbreviation & Denotation \\
\hline A498 & Renal carcinoma cell line \\
\hline $\mathrm{ACN}$ & Acetonitrile \\
\hline $\mathrm{ADP}$ & Adenosine diphosphate \\
\hline AICAR & 5-aminoimidazole-4-carboxamide ribonucleotide transformylase \\
\hline APL & Acute promyelocytic leukaemia \\
\hline APS & Ammonium persulfate \\
\hline CHAPS & 3-(3-cholamidopropyl)-dimethylammoniopropane sulfonate \\
\hline CyDyes & Cyanine dyes \\
\hline DHFR & Dihydrofolate reductase \\
\hline DH-123 & Dihydrorhodamine \\
\hline DMF & Dimethylformamide \\
\hline DMSO & Dimethyl sulfoxide \\
\hline DTT & Dithiothreitol \\
\hline EDTA & Ethylenediaminetetraacetic acid \\
\hline ER & Endoplasmic reticulum \\
\hline FCS & Fetal calf serum \\
\hline FLT3 & Fms-like tyrosine kinase 3 \\
\hline $\mathrm{H}_{2} \mathrm{O}_{2}$ & Hydrogen peroxide \\
\hline HL-60 & Acute promyelocytic leukaemia cell line \\
\hline HRP & Horseradish peroxidase \\
\hline $\mathrm{IC}_{60}$ & Inhibition concentration $(60 \%)$ \\
\hline ICMT & Isoprenylcysteine carboxyl methyltransferase \\
\hline IEF & Isoelectric focusing \\
\hline IPG & Immobilized $\mathrm{pH}$ gradient strip \\
\hline ITDs & Internal tandem duplications \\
\hline $\mathrm{kDa}$ & Kilodalton \\
\hline MTETS & Mitochondrial transmembrane electron transport system \\
\hline MTX & Methotrexate \\
\hline $\mathrm{NaCI}$ & Sodium chloride \\
\hline
\end{tabular}


$\mathrm{NADH}$

$\mathrm{NF}-\kappa \mathrm{B}$

NP-40

PAGE

PBS

PI3K

PLZF

PMSF

PtdSer

PteGlu

RTKs

SadoMet

SD

SDS

SV40

TCEP

TEMED

TFA

Tris

Tween

$\Delta \psi_{\mathrm{m}}$

Nicotinamide adenine dinucleotide; reduced form

Nuclear factor-kappa B

Nonylphenyl polyethylene glycol

Polyacrylamide gel electrophoresis

Phosphate buffer saline

Phosphoinositide-3-kinase

Promyelocytic leukaemia zinc finger protein

Phenylmethanesulfonyl fluoride

Phosphatidylserine

Pteroylglutamic acid

Receptor tyrosine kinases

S-adenosylmethionine

Standard deviation

Sodium dodecyl sulfate

Simian virus 40

Tris (2-carboxyethyl) phosphine hydrochloride

N,N,N',N'-Tetramethylethylenediamine

Trifluoracetic acid

Tris (hydroxymethyl) aminomethane

Polyoxyethylene (80) sorbitan monolaurate

Mitochondrial transmembrane potential 


\section{INTRODUCTION}

Leukaemias are malignant neoplasms of haematopoietic cells. They can be acute or chronic. The acute leukaemias are a heterogeneous group of neoplasm arising from transformation of uncommitted or partially committed haematopoietic stem cells. Acute leukaemias are in general divided into myeloid and lymphoid leukaemia. They differ not only in their clinical presentation but also substantially in response to therapy and following course. Although the French-American-British (FAB) morphologic classification of acute promyelocytic leukaemia (APL) vs. acute lymphoblastic leukaemia (ALL) has been accepted for many years (Leymarie et al., 2004), the important advances in cytogenetic, immunophenotype and genetic fields needed to be integrated in an updated approach to classify leukaemias.

The recognition of distinctive morphologies that correlate with the specific chromosomal translocation and development of treatments are based on specific genetic defects (LopezTerrada, 2006). Molecular genetic analysis of acute leukaemia has been at the forefront of research into the pathogenesis of cancer because the presence of recurring chromosomal translocations provides immediate clues to the genetic events and identifies the deregulated oncogenes leading to leukaemias (Ikeda et al., 2006).

\subsection{THE MOLECULAR BASIS OF LEUKAEMIAS}

Leukaemias are characterized by acquisition of recurring genetic aberrations. Important insights into the molecular basis of leukaemias have been obtained by inhibition of differentiation, deregulation of tyrosine kinases, and inappropriate proliferation in the absence of normal growth signals finally lead to cell death (Cline, 1994). These factors are often not sufficient to cause leukaemia and appear to be a part of the complex signalling network. Hence, understanding the impaired genes complex and related 
aberrant oncogenic cell signalling proteins have paved the way for new treatment modalities that target specific gene products implicated in cancer.

\subsubsection{Differentiation blockade: The role of transcription factors in APL}

The most common targets of leukaemia-associated chromosomal translocations are genes that encode DNA-binding transcription factors or regulatory component of transcriptional complexes (Look, 1997). A number of recurrent chromosomal translocations have been cloned and characterized in specific subtypes of leukaemia. For example, $t(15 ; 17)$ is mainly found in APL patients (Chou and Dang, 2005), whereas $t(1 ; 19)$ is basically involved in B-cell precursor ALL patients (Hunger, 1996).

Chromosomal translocations in APL can be broadly grouped into Hox family members, ETS family members, Core binding factors, and other transcriptional regulatory proteins. The most common translocation in APL is the fusion of the retinoic acid receptor- $\alpha$ chain either to the PML gene (PML-RAR $\alpha$ ) or to the promyelocytic leukaemia zinc finger protein (PLZF / RAR $\alpha$ ) (Chen et al., 1993). Transformation in each of these cases proceeds the generation of fusion protein that interferes in a dominant manner with the function of the wild type protein. This chromosomal rearrangements result in abnormal proliferation, lack of differentiation, and disruption of apoptosis thereby giving the leukaemia cells an advantage to expand abnormally in various in-vivo and in-vitro experimental models (Van Etten and Shannon, 2004).

\subsubsection{Core binding factors in $A P L$}

Genes that constitute the core binding factors are essential for haematopoiesis. Cloning of the AML-associated $t(8 ; 21)$ translocation led to the identification of AML1. It encodes DNA-binding subunit of AML1-CBF $\beta$, a transcription factor that regulates a number of haematopoiesis specific genes and is essential for the development of haematopoietic cell 
system (Wang et al., 1996). Fusion gene products formed by $\mathrm{t}(8 ; 21)$ translocation joins the N-terminal part of AML1 including the DNA-binding and CBF $\beta$ interaction domains, with the C-terminal portion of the $8 ; 21$ gene (ETO) on chromosome 8 (Yergeau et al., 1997). The resultant complex retains its ability to bind AML1-regulated target sequences and represses AML1-mediated transcription (Liu et al., 1993). Further evidences suggest that ETO's ability to repress transcription is mediated by its interaction with nuclear receptor corepressor $(\mathrm{N}-\mathrm{CoR})$ and recruitment of $\mathrm{N}-\mathrm{CoR} / \mathrm{Sin} 3$ / HDAC1 complex in the nucleus (Wang et al., 1998). By permanently tethering this repressive complex to AML1-responsive promoters, AML1-ETO actively suppresses transcription by maintaining the histones in a deacetylated conformation and making DNA inaccessible to the transcriptional apparatus. Hence, inhibition of AML1-responsive gene probably block myeloid development and leukaemic transformation in maturing haematopoietic progenitors (Wang et al., 1998).

\subsubsection{Molecular deregulation of receptor tyrosine kinases in APL}

Receptor tyrosine kinases (RTKs) are transmembrane proteins having ligand binding extra cellular domain and a catalytic intracellular kinase domain. In the absence of ligands, RTKs are monomeric, unphosphorylated and kinase domains are inactive. Binding of ligand to the extra cellular domain results in receptor oligomerization and autophosphorylation of the tyrosine residue within the activation loop of the kinase. Upon tyrosine phosphorylation, other signalling proteins are recruited to the membrane and intracellar signal cascade is activated (Ikeda et al., 2006). A common mechanism in leukaemias is the fusion of a receptor tyrosine kinase with a partner protein as a result of chromosomal translocation, e.g., BCR-ABL (Perrotti and Calabretta, 2004). 


\subsubsection{The BCR-ABL fusion gene and leukaemia}

Chronic promyelocytic leukaemia is a clonal stem cell disorder, which is characterized by a $\mathrm{t}(9 ; 22)(\mathrm{q} 34 ; \mathrm{q} 11)$ chromosomal translocation known as the Philadelphia chromosome (Sawyers, 1992). This classical translocation in leukaemia cells occurs by the fusion of two genes, BCR and $\mathrm{ABL}$ results in a formation of fused gene known as BCR-ABL. The fusion product is generally expressed as chimeric protein of $210 \mathrm{kDa}$ molecular weight (also known as p210) (Perrotti and Calabretta, 2004). p210 is over expressed in freshly isolated cells derived from patients with chronic promyelocytic leukaemia and contain tyrosine kinase activity (Lim et al., 1999). In addition to this, leukaemic cells expressing BCR-ABL are also protected from apoptosis by preventing cytosolic accumulation of cytochrome-c and inhibition of caspase 3 (Bedi et al., 1995; Bedi et al., 1994). Moreover, activation of Ras $\mathrm{G}$ proteins are required for transformation by $\mathrm{ABL}$ oncogenes, activate several signalling pathways such as the RAS signalling pathway, the JNK and STAT pathways as well as the phosphatidyl inositol-3-kinase pathway (Daley et al., 1990). Ras-GTP also contributes to the PI3-kinase pathway activation by binding a site within class I catalytic subunits (Rodriguez-Viciana et al., 1994).

\subsubsection{Activated mutation in Fms-like tyrosine kinase-3 receptor}

Fms-like tyrosine kinase-3 (FLT3) is a tyrosine kinase receptor, involved in stem cell proliferation, increase invasiveness, angiogenesis and metastasis (Krause and Van Etten, 2005). FLT3 is a most common mutated gene in APL and is constitutively activated by acquired mutation in approximately $12-42 \%$ of APL patients (Thiede et al., 2002). Two types of mutations have been attributed to the deregulated FLT3 receptor. Firstly, in most cases of APL, there are internal tandem duplication (ITD) mutations in the juxtamembrane domain of FLT3, ranging in size from several to $>50$ amino acids (Grundler et al., 2005). These mutations are always in frame and the diversity of 
mutations among patients has suggested that there may be the loss-of-function mutations in an auto inhibitory domain. ITD mutations occur exclusively within 27-amino acids stretch and lead to structural inactivation of the tyrosine kinase. Clinical studies identify ITD mutations in 17-26 \% of APL cases (Moreno et al., 2003).

Secondly, a small percentage of APL mutations occur in the activation loop of FLT3 resulting in constitutive kinase activation. The most common activating point mutation is the substitution of tyrosine for aspartic acid at position 835 within the activation loop of the kinase domain (Yamamoto et al., 2001). Point mutations at other positions, such as 836 and 841 have also been associated with FLT3 independent activation of tyrosine kinase activity (Thiede et al., 2002). The FLT3-D835 mutation is observed in $7 \%$ of APL cases (Murphy et al., 2003; Levis and Small, 2003). Thus, FLT3 appears to be necessary for disease progression in APL and is therefore a potential target for leukaemic therapy.

\subsubsection{Inappropriate proliferation: The role of signalling molecules}

It has been proved in leukaemias that activation of specific genetic programs that are coordinated by signal transduction pathways of growth factor and cytokine stimulation can determine cell division, apoptosis, or differentiation. The RAS signalling pathway is mainly activated by a spectrum of haematopoietic cytokine receptors in response to ligand stimulation and play an important role in the proliferation of haematopoietic progenitors (Bartek and Lukas, 2001). Members of the RAS gene family (K-RAS, N-RAS and H-RAS) are key oncogene homolog, involved in a number of signal transduction pathways. Oncogenic N-RAS and K-RAS mutations are generally found in approximately $25 \%$ in APL, $30 \%$ in myeloma and 6-20\% in ALL patients (Padua et al., 1998). These mutations frequently involve single amino acid substitution at codons 12,13 , or 61 in the GTP binding site that abrogate intrinsic RAS GTPase activity and lead to constitutive RAS activation (Neri et al., 1988; Gougopoulou et al., 1996). 
RAS oncogenic proteins undergo a complex series of posttranslational modifications before they are fully functional. These modifications occur at the C-terminal CAAX motif and are initiated by the addition of an isoprenoid lipid through a process known as prenylation (Hancock et al., 1989). Following prenylation, these proteins usually undergo endoproteolytic processing by RCE1 protease and then carboxyl methylation by a unique methyltransferase known as isoprenylcysteine carboxyl methyltransferase (ICMT) (Winter-Vann and Casey, 2005). Although inhibitors targeting the prenylation step are now in advanced-stage clinical trials, but their therapeutic utility and efficacy seems to be limited (Morgan et al., 2003). Recent findings indicate that the inhibition of the postprenylation processing steps, particularly ICMT catalysed methylation might provide a better approach to the control of cancer cell proliferation (Winter-Vann and Casey, 2005). NF- $\kappa \mathrm{B}$ (Nuclear factor-kappa B) signalling pathway is also commonly found in all haematopoietic cell types and involved in haematopoietic cell survival (Pyatt et al., 1999), erythropoiesis (Zhang et al., 1998), neutrophil activation (McDonald et al., 1997); B-cell and T-cell development (Grumont et al., 1998). Abnormalities in the NF-אB regulation has been associated with the development of human lymphomas (Neri et al., 1991). Furthermore, a number of reports have shown that activation of NF- $\kappa \mathrm{B}$ is critical for the pathogenesis of leukaemias (Baumgartner et al., 2002; Braun et al., 2006; Bueso-Ramos et al., 2004; Guzman et al., 2001).

It had already been shown that human leukaemic cells expressed abnormally high level of proteasomes as compared to normal peripheral blood cells (Kumatori et al., 1990) Therefore, it seems to be reasonable that proteasome inhibitors initiate apoptosis in leukaemic cells. While proteasome inhibitors function through multiple pathways, the most important one is the blocking of the survival signals regulated by NF- $\kappa \mathrm{B}$ (Adams, 2004). This observation is consistent with studies in many cancer types, indicating a 
central role of NF- $\mathrm{NB}$ in promoting tumour growth and survival of cancer patients (Karin, 2006).

\subsubsection{Escape from apoptosis}

In normal haematopoiesis, there is a fine balance between proliferation and apoptosis, reflecting coordination between pro and anti-apoptotic genes (Schulte-Hermann et al., 1999). In cancer cells, this delicate balance is disrupted by a number of mutations result in increasing the anti-apoptotic gene expression and thereby shifting this balance in favour of proliferation. BCL-2 is a proto-oncogene that was originally cloned from a follicular lymphoma $\mathrm{t}(14 ; 18)$ translocation (Tsujimoto et al., 1985). It encodes mainly mitochondrial protein and promotes cell survival by blocking the release of cytochrome- $c$ thus preventing caspase activation (Rosse et al., 1998). BCL-2 also suppresses p53 and c-Myc dependent apoptosis (Sachs and Lotem, 1993). Small interfering RNA against BCL-2 has been found to be effective in primary APL cells (Reed, 2003).

\subsection{CURRENT THERAPIES AND FUTURE DIRECTIONS}

Initially, the combination chemotherapy for APL has consisted of induction with cytarabine (Ara-C) and anthracycline followed by consolidation with Ara-C (Stone, 2002). While this approach achieves remission for a majority of APL patients, relapse is common and long-term survival rates remain low. Recent experimental evidences indicate that both Ara-C and anthracycline are less effective in primitive APL cells as compared to leukaemic blasts (Costello et al., 2000; Guzman et al., 2001). Therefore, targeted therapy is a frontline treatment for haematological malignancies and became the novel treatment modalities for leukaemia patients. The differential clinical outcomes associated with the APL can be attributed primarily to drug sensitivity or resistance of promyelocytic cells harbouring specific genetic abnormalities (Daley et al., 1990; Pyatt et al., 1999; Thiede et 
al., 2002; Wang et al., 1998; Wang et al., 1996). Although the mechanism of leukaemic transformation is not precisely known, patients with this abnormality have a favourable prognosis when they are treated with folate analogues based regimens (Rots et al., 2001; Goker et al., 1995). The unique sensitivity of leukaemic cells to MTX correlates with their propensity to undergo spontaneous apoptosis when cultured in vitro and to have higherthan-average intracellular concentrations of MTX and its active polyglutamate after in vivo treatment (Rots et al., 2001).

\subsection{ANTI-METABOLITES (FOLIC ACID ANALOGUES)}

Dihyrofolate reductase (DHFR) is a primary site of action for most folate analogues. Inhibition of DHFR leads to toxic effects through partial depletion of tetrahydrofolate $\left(\mathrm{FH}_{4}\right)$ cofactors that are required for the purine and thymidylate synthesis (Genestier et al., 2000). Various chemotherapeutic agents have been identified having weak affinity with human DHFR and strong activity against bacterial and parasitic infections. By contrast, MTX is an effective inhibitor of DHFR in all species. Crystallographic and oligonucleotide-directed mutagenesis studies explained high affinity and species specificity of MTX with DHFR (Blakley and Sorrentino, 1998; Matthews et al., 1985; Schweitzer et al., 1989; Stone and Morrison, 1986).

\subsubsection{History of MTX}

MTX, a folate analogue, first synthesized by Sidney Farber in collaboration with Harriett Kilte and Lederle chemists. It was the first example of rational drug design developed for the treatment of ALL (Farber, 1950). It was further reported to cure choriocarcinoma (Berlin et al., 1963). The consistent cure of choriocarcinoma by MTX provided great impetus to investigations into the chemotherapy of cancer. Besides its anticancer activity, MTX is widely used in the treatment of psoriasis, rheumatoid arthritis (Takimoto and 
Allegra, 1995) primary biliary cirrhosis, Crohn's disease, and intrinsic asthma (Genestier et al., 2000).

\subsubsection{Chemistry and metabolic activities of folates}

The structural formula of pteroylglutamic acid (PteGlu) is shown in Figure 1. Major part of the molecule includes pteridine ring linked by a methylene bridge to paraminobenzoic acid, which is joined by an amide linkage to glutamic acid. While PteGlu is the common pharmaceutical form of folic acid, it is neither the principle folic acid congener in food nor the active coenzyme for intracellular metabolism. Following absorption PteGlu is rapidly reduced to dihydrofolate $\left(\mathrm{FH}_{2}\right)$ and subsequently to tetrahydrofolate $\left(\mathrm{FH}_{4}\right)$. Both these sequential reactions are carried out in the presence of DHFR.

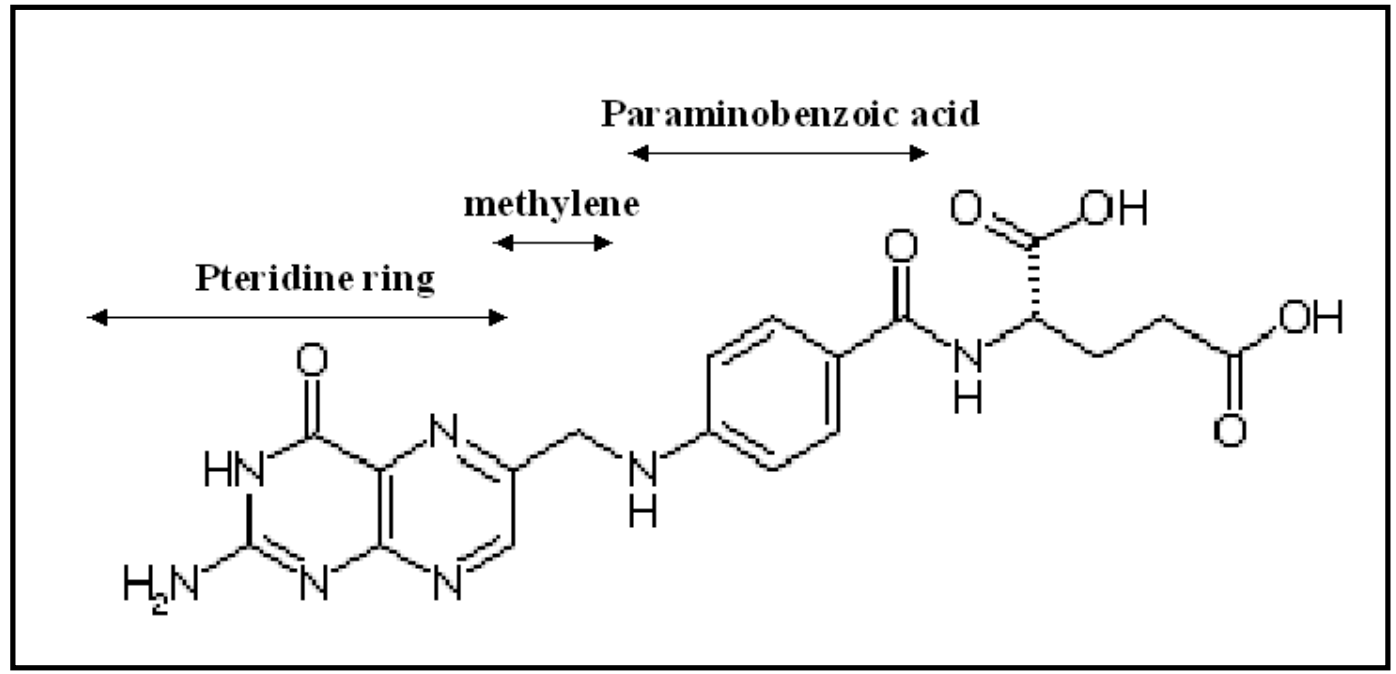

Figure 1. The chemical structure of pteroylglutamic acid (folic acid)

In the form of a series of $\mathrm{FH}_{4}$ compounds, folate accepts one-carbon units from donor molecule and plays a specific role in the intracellular metabolism (Choi and Mason, 2000) summarized as follows: 
A. Utilization or generation of formate. This reversible reaction utilizes $\mathrm{FH}_{4}$ and 10-methyltetrahydrofolate $\left(\mathrm{CH}_{3} \mathrm{FH}_{4}\right)$.

B. Conversion of serine to glycine. This reaction requires $\mathrm{FH}_{4}$ as an acceptor of a methylene group from serine and utilizes pyridoxal phosphate as a cofactor resulting in the formation of 5, 10-methylenetetrahydrofolate $\left(\mathrm{CH}_{2} \mathrm{FH}_{4}\right)$, an essential coenzyme for thymidylate synthesis.

C. Histidine metabolism. $\mathrm{FH}_{4}$ also acts as an acceptor of a formimino group in the conversion of formiminoglutamic acid to glutamic acid.

D. Conversion of homocysteine to methionine. Methionine is regenerated from homocysteine in a reaction catalysed by an enzyme known as $\mathrm{CH}_{3} \mathrm{FH}_{4}$ homocysteine methyltransferase. This reaction requires $\mathrm{CH}_{3} \mathrm{FH}_{4}$ as a methyl donor and utilizes vitamin $\mathrm{B}_{12}$ as a cofactor. Further, methionine is converted into S-adenosylmethionine (SAM) in a reaction catalysed by methionine adenosyl transferase. SAM then donates the labile methyl group for over than 80 biological methylation reactions, including an array of reactions whereby specific sites within DNA and RNA become methylated (Figure 2).

E. Nucleic acid metabolism. The synthesis and turnover of deoxynucleoside triphosphate (dNTP) pools are tightly coupled to DNA synthesis. dNTPs are the immediate source of substrates for the polymerase reactions involved in DNA replication. Therefore, deoxynucleotides are critical for DNA synthesis. Folate derived one-carbon groups are essential for the de novo synthesis of the thymidylate and the purines. 
- Synthesis of thymidylate. $\mathrm{CH}_{2} \mathrm{FH}_{4}$ donates a methylene group and reducing equivalents to deoxyuridylate for the synthesis of thymidylate, a ratelimiting step in DNA synthesis.

- (b) Synthesis of purine. Two steps in the synthesis of purine nucleotides require the participation of derivatives of folic acid. Glycinamide ribonucleotide is formylated by 5, 10-methenyltetrahydrofolate $\left(\mathrm{CHFH}_{4}\right)$; AICAR is formylated by 10 -formyltetrahydrofolate $\left(\mathrm{CHOFH}_{4}\right)$.

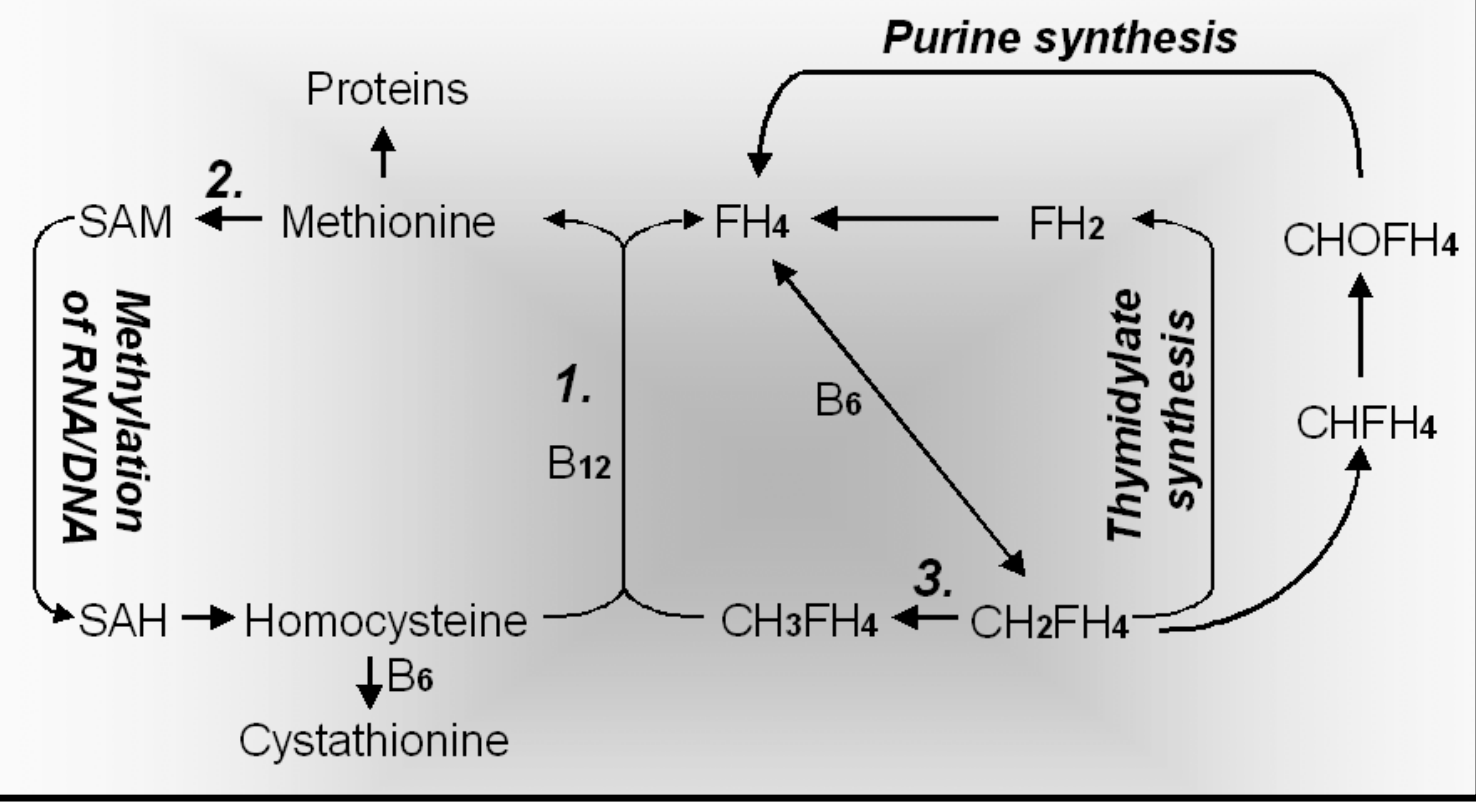

Figure 2. Folate in nucleic acid metabolism

$\mathrm{FH}_{4}$, tetrahydrofolate; $\mathrm{FH}_{2}$, dihydrofolate; SAM, S-adenosylmethionine; SAH, S-adenosylhomocysteine; (1) methyltetrahydrofolate homocysteine methyltransferase; (2) methionine adenosyl transferase; (3) methylenetetrahydrofolate reductase (Adapted from Choi and Mason, 2000) 


\subsubsection{Mechanism of action of MTX}

MTX is a potent inhibitor of DHFR $\left(\mathrm{K}_{i} \approx 0.01\right.$ to $\left.0.2 \mathrm{nM}\right)$, prevents the formation of $\mathrm{FH}_{4}$, producing an intracellular deficiency of certain folate coenzymes leading to accumulation of the toxic inhibitory substrate known as polyglutamate (Figure 3). However, it has been noted in some experimental models that the inhibition of folic acid metabolism could not be completely responsible for the antiproliferative effect of MTX (Sant et al., 1992). The one-carbon transfer reactions play a crucial role in the de novo synthesis of purine nucleotides and thymidylate synthesis with the subsequent interruption of the DNA and RNA synthesis (Allegra et al., 1985) as depicted in Figure 2. A number of other important observations have been made which point towards the additional molecular influences of MTX such as inhibition of the ICMT (Winter-Vann et al., 2003) and suppression of the NF- $\kappa \mathrm{B}$ subunits $\mathrm{p} 65$ and $\mathrm{p} 50$. The suppression of the NF- $\kappa \mathrm{B}$ was accompanied by inhibition of IKB $\alpha$ phosphorylation and degradation (Majumdar and Aggarwal, 2001). Nevertheless, the molecular targets and their underlying pathways that are activated by MTX and lead to apoptosis in cancers are still not well defined. 


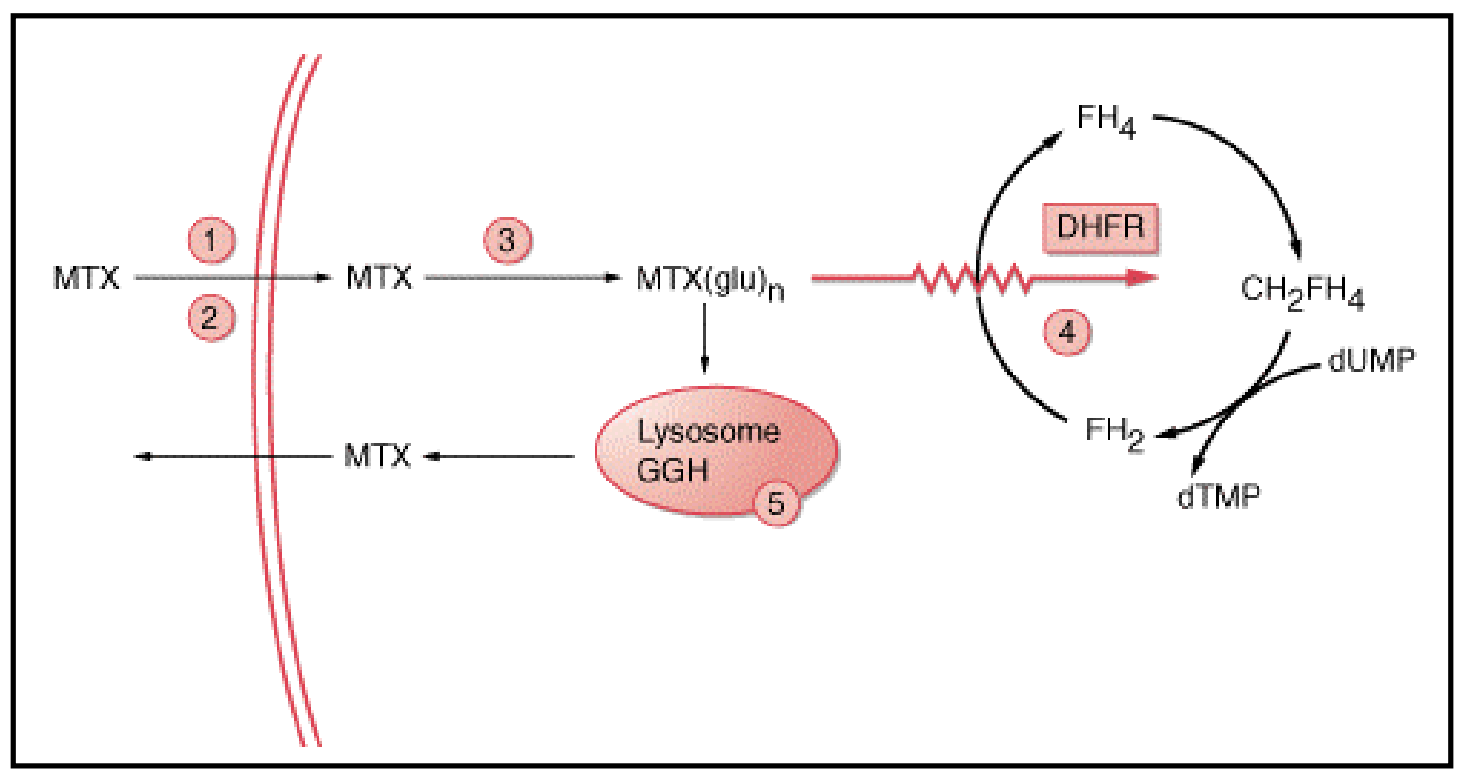

Figure 3. Sites of action of MTX and MTX polyglutamates

MTX enters into the cells by either the reduced folate carrier (1) or the membrane folate binding protein (2). MTX is then polyglutamylated by the enzyme folylpolyglutamate synthetase (3). MTX (glu) $)_{\mathrm{n}}$ is a potent inhibitor of dihydrofolate reductase (DHFR) (4). MTX polyglutamates are hydrolyzed to MTX in the lysosome by g-glutamyl hydrolase (GGH) (5). $\mathrm{CH}_{2} \mathrm{FH}_{4}=5,10$-methylene tetrahydrofolate; dTMP = deoxythymidine monophosphate; dUMP $=$ deoxyuridine monophosphate/deoxyuridylate; $\mathrm{FH}_{2}=$ dihydrofolate; $\mathrm{FH}_{4}=$ tetrahydrofolate; MTX = methotrexate; MTX $(\mathrm{glu})_{\mathrm{n}}=$ methotrexate polyglutamate with n glutamate residues (Adapted from Cancer Medicine 6, 2003). 


\section{AIM OF THE STUDY}

MTX was used to treat choriocarcinoma and trophoblastic cancers (Homesley et al., 1988; Goldstein et al., 1976); cure rate was $90 \%$ in early cases and $75 \%$ in advance cases after exposure to MTX and dactinomycin. Beneficial effects were also observed in patients with osteosarcoma (Souhami et al., 1997) and mycosis fungoides (Groth et al., 1979), when MTX was used as part of the combination therapy. High doses of MTX, with leucovorin rescue, can cause substantial tumour regression in Burkitt's and non-Hodgkin's lymphomas, and carcinomas of breast, head, neck (Frei, III et al., 1980). Recently, in many clinical trials MTX has been established as an effective treatment of leukaemias and other cancers (Levine et al., 2005; Winter et al., 2006; Whitehead et al., 2005).

Therefore, it is of utmost importance to understand the complete molecular mechanism of MTX in the treatment of cancer, particularly leukaemia. Towards this aim, the present study was design to identify the molecular targets and their underlying molecular mechanisms affected by MTX in different cancer cell types using functional proteomic approach. 


\section{MATERIALS}

\subsection{REAGENTS}

L-glutamine, Penicillin, Streptomycin, MTX, DTT, and Iodoacetamide were purchased from Sigma-Aldrich Chemie GmbH, Steinheim, Germany. CHAPS [(3Cholamidopropyl) dimethyl-ammonio] -1-propanesulfonate] was obtained from Merck KGaA, Darmstadt, Germany. Precision plus protein marker was purchased from Bio-Rad Laboratories, CA, USA. Protease inhibitor Mix 100 was obtained from Amersham Biosciences GmbH, Freiburg, Germany. A Sequazym ${ }^{\mathrm{TM}}$ peptide Mass standard Kit was purchased from Applied Biosystems, CA, USA.

\subsection{CELL LINES}

HL-60 and A498 cell lines were obtained from DSMZ GmbH, Braunschweig, Germany and ATCC, Manassas, USA, respectively. Cell lines basic properties are briefly described as follow:

\subsubsection{HL-60 cell line (Human promyelocytic leukaemia cell)}

The HL-60 cell line, derived from an APL patient (Collins et al., 1977), proliferates continuously and consists predominantly of a neutrophilic promyelocyte with prominent nuclear / cytoplasmic asynchrony. These cells represent a transformed phenotype, form colonies in semisolid medium and produce subcutaneous myeloid tumours in nude mice. The morphological and histochemical karyotypic similarity; responsiveness to chemical induction of differentiation is essentially unchanged to the patient's leukaemic cells (Gallagher et al., 1979). Therefore, HL-60 cell line provides a continuous source of human cells for studying molecular events of APL proliferation and the effects of various physiological and pharmacological agents on this process. 
URL link:

http://www.dsmz.de/human and animal cell lines/info.php?dsmz nr=3\&term=ACC$\underline{3 \& \text { highlight }=}$

\subsubsection{A498 cell line (Renal epithelial carcinoma cell)}

ATCC Number

Species

Source

Disease

Growth properties

Morphology

Tumorigenic

URL link:

http://www.lgcpromochematcc.com/common/catalog/numSearch/numResults.cfm?atccN $\underline{\mathrm{um}}=\mathrm{HTB}-44$
HTB-44 TM

Homo sapiens

Kidney

Renal cell carcinoma

Adherent

Epithelial

Nude mice; forms undifferentiated carcinoma; also forms tumours in anti thymocyte serum treated newborn mice. 


\subsection{BUFFERS AND SOLUTIONS}

Following buffers and solutions are most frequently used in the Experimental Procedures.

Others are cited in the text.

Standard Culture Medium

DMEM and RPMI

$10 \%(\mathrm{v} / \mathrm{v}) \mathrm{FCS}$

$1 \%(\mathrm{v} / \mathrm{v})$ L-Glutamine

$1 \%(\mathrm{v} / \mathrm{v})$ Penicillin /Streptomycin

Cell Lysis Buffer (2D gel electrophoresis) $9.5 \mathrm{M}$ urea

$2 \% \mathrm{w} / \mathrm{v}$ CHAPS

$2 \% \mathrm{v} / \mathrm{v}$ ampholytes

$1 \% \mathrm{w} / \mathrm{v}$ DTT

$10 \mathrm{mM}$ PMSF adjust $\mathrm{pH} 7.5$ with appropriate acid/base

Electrophoresis Buffer (5x)

$125 \mathrm{mM}$ Tris

$1 \mathrm{M}$ Glycine

$0.5 \% \mathrm{w} / \mathrm{v}$ SDS

Colloidal Coomassie staining solution

$40 \% \mathrm{v} / \mathrm{v}$ Methanol

$40 \% \mathrm{v} / \mathrm{v}$ Water

$20 \% \mathrm{v} / \mathrm{v}$ Coomassie solution

\section{Silver staining solutions}

Fixation solution

$50 \% \mathrm{v} / \mathrm{v}$ Methanol

$12 \% \mathrm{v} / \mathrm{v}$ Acetic acid

$38 \% \mathrm{v} / \mathrm{v}$ Water

Wash solution I

$50 \% \mathrm{v} / \mathrm{v}$ Ethanol

$50 \% \mathrm{v} / \mathrm{v}$ Water

Wash solution II

$30 \% \mathrm{v} / \mathrm{v}$ Ethanol

$70 \% \mathrm{v} / \mathrm{v}$ Water

Sensitising solution

$0.02 \% \mathrm{v} / \mathrm{v}$ Sodium thiosulphate

$99.98 \% \mathrm{v} / \mathrm{v}$ Water

Silver nitrate solution

$0.2 \% \mathrm{w} / \mathrm{v}$ Silver nitrate solution

$0.026 \% \mathrm{v} / \mathrm{v}$ Formaldehyde solution

Rest water 
Developing solution

Stop solution

Storage solution

Wash Buffer (1x)
$6 \% \mathrm{w} / \mathrm{v}$ Sodium thiosulphate

$0.0185 \% \mathrm{v} / \mathrm{v}$ Formaldehyde solution

$50 \% \mathrm{v} / \mathrm{v}$ Methanol

$12 \% \mathrm{v} / \mathrm{v}$ Acetic acid

$38 \% \mathrm{v} / \mathrm{v}$ Water

$5 \% \mathrm{v} / \mathrm{v}$ acetic acid solution

$10 \mathrm{mM}$ Tris-HCl, $\mathrm{pH} 7.5$

$0.1 \% \mathrm{v} / \mathrm{v}$ Tween-20

$100 \mathrm{mM} \mathrm{NaCl}$

\subsection{EQUIPMENTS}

Following equipments were most frequently used during the course of this study. Others are cited in the Experimental Procedures.

\section{Appliance}

Centrifuge Biofuge 15R

Centrifuge Sigma 3-18K

Consort Power Supply E815

Electrophoretic Transfer Cell

Filtration pump SM18059

Gel chambers

Heater IKAMAG REO

Laboratory balance

Lab-Shaker

Laminar Air Flow Safety Workbench

BSB 4A

Mini Trans-Blot ${ }^{\circledR}$ Electrophoretic

Transfer Cell

\section{Manufacturer}

Herapus Sepatech, Osterode, Germany

Sigma, Osterode, Germany

Sigma, Steinheim, Germany

BioRad, Munich, Germany

Sartorius, Göttingen, Germany

BioRad, Munich, Germany

Schütt Labortechnik, Göttingen, Germany

Sartorius, Göttingen, Germany

Braun, Melsungen, Germany

Gelaire Flow Laboratories, Opera, Italy

BioRad, Munich, Germany 
pH meter PB-11

Speed vac SVC 10CH

Thermo mixer comfort

Vortexer REAX 2000

Water bath GFL 1003

Water-jacketed CO2-Incubator
Sartorius, Göttingen, Germany

Savant, Holbrook, USA

Eppendorf, Hamburg, Germany

Heidolph, Schwabach, Germany

GFL, Burgwedel, Germany

Labotect, Göttingen, Germany

\subsection{SCIENTIFIC ONLINE SEQUENCES AND SOFTWARE SERVICES}

The following scientific software and databank sequences were used during the course of this study.

Program Use Reference

Blast Protein sequence database http://www.ncbi.nlm.nih.gov/blast/

Entrez Pubmed Sequence retrieval http://www.ncbi.nlm.nih.gov/entrez/

Mascot Protein database search $\quad \underline{w w w . m a t r i x s c i e n c e . c o m}$

WinMDI Flow cytometric applications $\underline{\underline{1 . h t m}}$

http://facs.scripps.edu/help/html/read1pt 


\section{EXPERIMENTAL PROCEDURES}

\subsection{CELL CULTURE PROCEDURES}

HL-60 and A498 cell lines were maintained in RPMI and DMEM medium (Gibco, Paisley, UK) containing 5.5 mM D-glucose supplemented with $10 \%$ fetal calf serum, $1 \%$ L-glutamine and $1 \%$ Penicillin/Streptomycin. Cells were routinely cultured and incubated until $70 \%$ confluency in $75 \mathrm{~cm}^{2}$ tissue culture flasks in a humidified $5 \% \mathrm{CO}_{2} / 95 \%$ air atmosphere at $37{ }^{\circ} \mathrm{C}$.

\subsection{CELL VIABILITY ASSAY}

Cell viability was determined by standard trypan blue exclusion assay (Kaltenbach et al., 1958). Briefly, control and MTX treated HL-60 cells were plated on 24-well dishes (Sarstedt, Newton, USA) at the density of $1 \times 10^{5}$ cells $/ \mathrm{mL}$ in complete RPMI medium for 72 hours at $37^{\circ} \mathrm{C}$. Subsequently, cells were harvested, washed with phosphate buffer saline (PBS) and $0.4 \%$ trypan blue stain (Sigma-Aldrich, Missouri, USA) was added in equal volume of cell containing PBS buffer. Trypan blue positive and negative cells were counted using a haemocytometer (Hausser Scientific, Horsham, PA) under an ID 03 light Microscope (Zeiss, Oberkochen, Germany).

\subsection{DETECTION OF PHOSPHATIDYLSERINE BY ANNEXIN-V}

Apoptosis is associated by a loss of membrane phospholipids symmetry, resulting in the exposure of phosphatidylserine (PtdSer) at the plasma membrane (Fadok et al., 1992). This exposure of PtdSer was quantified by flow cytometry (Koopman et al., 1994), using the binding of fluorescein isothiocyanate (FITC) labeled annexin-V to PtdSer. Control and MTX treated HL-60 and A498 cells were incubated in complete RPMI and DMEM medium in a humidified $5 \% \mathrm{CO}_{2} / 95 \%$ air atmosphere at $37^{\circ} \mathrm{C}$ for 72 hours. 
Subsequently, cells were harvested, washed with PBS and centrifuged briefly for $200 \mathrm{x} \mathrm{g}$ at $4{ }^{\circ} \mathrm{C}$. The annexin-V assay (Roche, Indianapolis, USA) was performed according to the manufacturer's instructions. Briefly, cell pellet of each sample was resuspended in the provided binding buffer, centrifuged at $200 \times \mathrm{g}$ for 1 minute at $4{ }^{\circ} \mathrm{C}$ and again resuspended in $200 \mu \mathrm{L}$ binding buffer. $5 \mu \mathrm{L}$ of FITC labelled annexin-V conjugate was added into the sample and incubated for $15 \mathrm{~min}$ at $22{ }^{\circ} \mathrm{C}$. The signal generated by FITC-labeled-annexin-V was analyzed in the FACSCalibur Flow Cytometer (BD Biosciences, Rockville, USA) using a single laser emitting excitation light at $488 \mathrm{~nm}$.

\subsection{CELL LYSATE PREPARATION FOR TWO DIMENSIONAL GEL ELECTROPHORESIS}

Cell lysates were prepared as described by Dihazi and their colleagues (Dihazi et al., 2005). Briefly, each group of HL-60 cells was centrifuged at $200 \mathrm{x}$ g for 10 minutes at $4{ }^{\circ} \mathrm{C}$. The obtained cell pellet was further incubated in $0.3-0.5 \mathrm{~mL}$ lysis buffer containing $9.5 \mathrm{M}$ urea, $2 \% \mathrm{w} / \mathrm{v}$ CHAPS, $2 \% \mathrm{v} / \mathrm{v}$ ampholytes, $1 \% \mathrm{w} / \mathrm{v}$ DTT, $10 \mathrm{mM}$ PMSF at $4{ }^{\circ} \mathrm{C}$ for 30 minutes with intermittent vortexing. For removing cells debris, samples were centrifuged twice at $4500 \mathrm{xg}$ for 45 minutes at $4{ }^{\circ} \mathrm{C}$. The obtained lysates were either used immediately or were kept frozen at $-80^{\circ} \mathrm{C}$ until use.

\subsection{PROTEIN PRECIPITATION AND ESTIMATION}

Protein precipitation was done according to the instructions of Ready Prep 2D cleanup kit, provided by the manufacturer (Bio-Rad, Hercules, USA). Briefly, protein sample $(100-500 \mu \mathrm{g})$ in a final volume of $100 \mu \mathrm{L}$ was transferred into a $1.5 \mathrm{~mL}$ micro centrifuge tube. Then $300 \mu \mathrm{L}$ of precipitating agent 1 was added and mixed by vortexing. After incubation on ice for 15 minutes, $300 \mu \mathrm{L}$ of precipitating agent 2 was added and mixed by vortexing. The tubes were centrifuged at $4500 \mathrm{x} g$ for 5 minutes to form a tight pellet. The 
supernatant was decanted and the tubes were repositioned as before and centrifuged at $4500 \mathrm{x} g$ for 5 minutes. Any residual liquid at the bottom of the tubes was removed. Then, $40 \mu \mathrm{L}$ of wash agent 1 was added on top of the pellet and the tubes were further centrifuged at $4500 \times \mathrm{g}$ for 5 minutes. The supernatant was removed and discarded. Ultra pure water $(25 \mu \mathrm{L})$ was added to the tubes and mixed by vortexing $10-20$ seconds. An additional $1 \mathrm{~mL}$ of wash agent 2 (pre-chilled at $-20{ }^{\circ} \mathrm{C}$ for $>1$ hour) and $5 \mu \mathrm{L}$ of washing additive 2 were mixed by vortexing for 1 minute. During the following incubation period (at $-20{ }^{\circ} \mathrm{C}$ for 30 minutes), the tubes were vortexed for 30 seconds at every 10 minutes interval. The pellet was formed by centrifugation at $4500 \mathrm{x} g$ for 5 minutes. The supernatant was discarded and the pellet air-dried for $<5$ minutes. The pellet was resuspended by adding lysis buffer followed by vortexing for 1 minute, incubation at room temperature for 3-5 minutes and vortexing again for 1 minute. The tubes were centrifuged at $4500 \mathrm{x} g$ for 15 minutes to clarify the protein sample. The supernatant was then ready for isoelectric focusing (IEF). The obtained pure supernatants were used immediately for experiments or stored at $-80{ }^{\circ} \mathrm{C}$ until analysis. Total protein concentration was measured according to the Bradford method (Bradford, 1976) using bovine serum albumin (Sigma, Steinheim, Germany) as a standard.

\subsection{PROTEIN CYDYES SATURATION LABELLING}

The CyDyes for saturation labelling have maleimide reactive groups. These dyes were covalently bound to the cysteine residues of proteins via a thioether linkage. To achieve maximal labelling of the cysteine residues, we used a high fluorchrome to protein labelling ratio protocol. CyDyes stock solutions were prepared by dissolving the solid dyes separately in high standard anhydrous DMF, aliquoting into $10 \mu \mathrm{L}$ working solutions and stored at $-80^{\circ} \mathrm{C} .5 \mu \mathrm{g}$ of the protein samples (lysates from untreated vs. MTX-treated cells) were equalized with lysis buffer (containing no ampholytes and DTT) and 
separately adjusted to $\mathrm{pH} 7.5$ with appropriate acid/base titrations. For the reduction of protein cysteines, cell lysates were incubated with 2 nmol Tris (2-carboxyethyl) phosphine hydrochloride (TCEP; Sigma, Steinheim, Germany) at $37^{\circ} \mathrm{C}$ in the dark for 1 hour. The mechanism of protein-dye labelling reaction is shown in Figure 4.

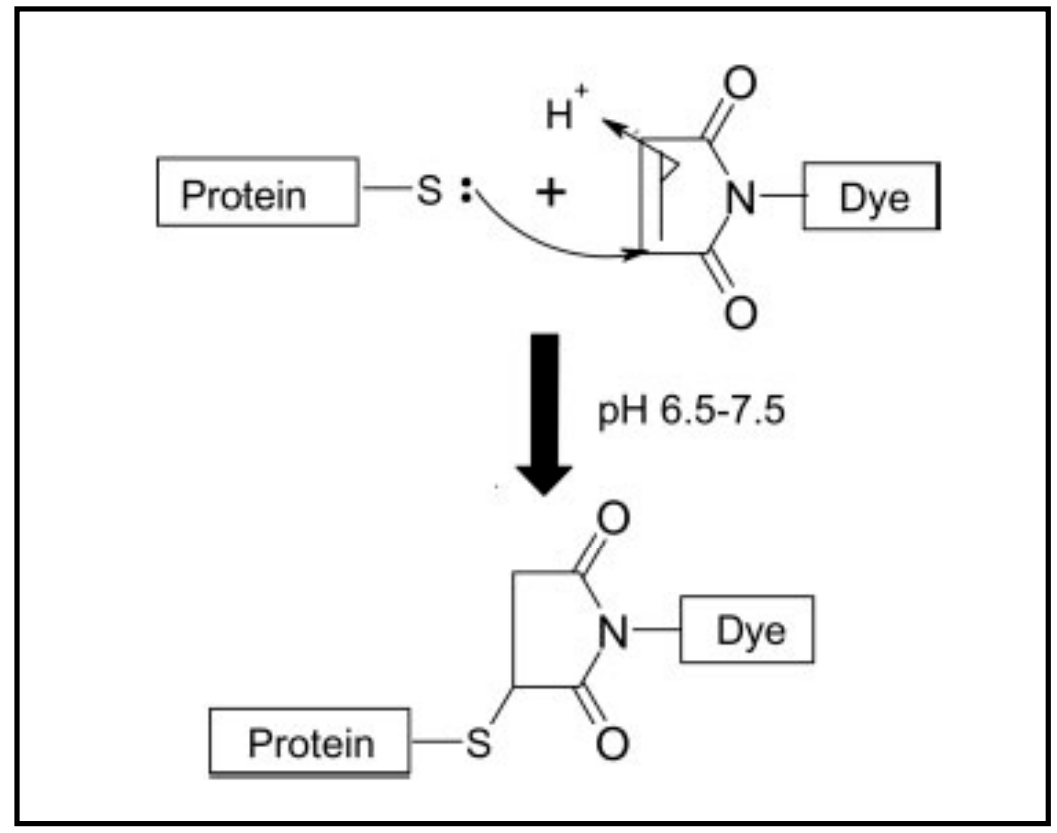

Figure 4. Schematic diagram of labelling reaction of protein thiols with maleimide CyDyes

4 nmol CyDyes (Amersham Biosciences, Freiburg, Germany) were added to the reduced sample, vortexed, centrifuged briefly and kept at $37^{\circ} \mathrm{C}$ in the dark for next 30 minutes. The labelling reactions were stopped with sample buffer containing DTT and ampholyte 3/10 solution (Bio-Rad, Hercules, CA, USA) and finally, the contents were mixed well and used for rehydration. The workflow of such proteomic analysis is shown in Figure 5. 


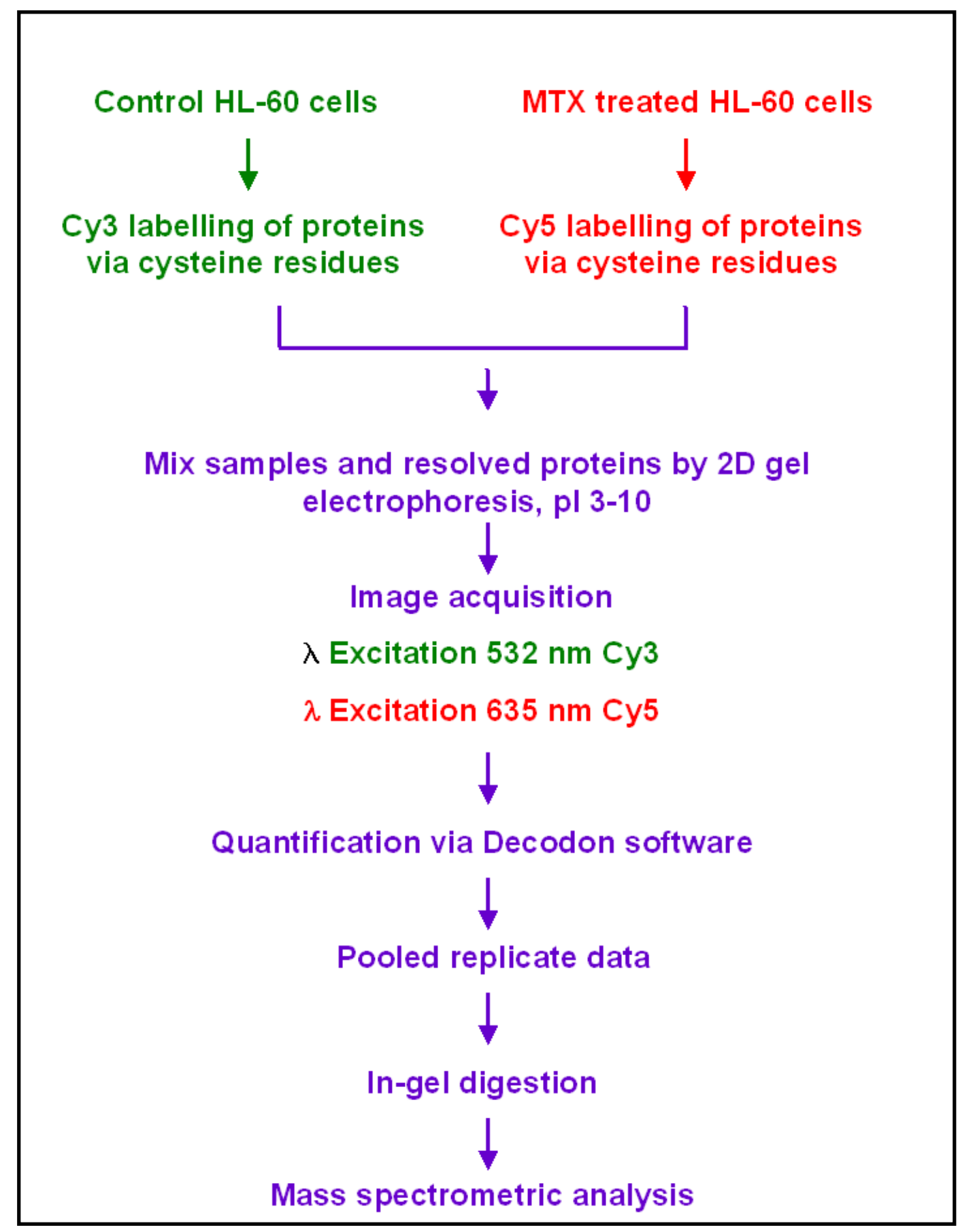

Figure 5. Workflow for cysteine labelled differential in-gel electrophoresis analysis

Cysteine labelled differential in-gel electrophoresis of untreated and MTX treated HL-60 cells were performed using Cy3 (green colour) and Cy5 (red colour) dyes, respectively. The protocol outlined above allows comparison of protein expression profiles, protein quantification, and identification of proteins of interest. 


\subsection{TWO DIMENSIONAL GEL ELECTROPHORESIS}

Each sample was diluted to a final volume of $315 \mu \mathrm{L}$ in rehydration buffer $(8 \mathrm{M}$ urea, $1 \%$ w/v CHAPS, $0.2 \% \mathrm{v} / \mathrm{v}$ ampholytes $\mathrm{pH} 3-10$, DTT $15 \mathrm{mM}$ and traces of bromphenol blue). This mixture was further used for rehydration of IPG strip. The ReadyStrip ${ }^{\mathrm{TM}}$ IPG strips $(\mathrm{pH} 3-10,17 \mathrm{~cm})$ were allowed to rehydrate for 1 hour before adding mineral oil (Bio-Rad, Hercules, USA). The passive hydrations of the IPG strips were carried out overnight at room temperature in a focusing chamber. The tray was transferred to the cooling platform of a PROTEAN IEF cell and isoelectric focusing was performed at $20^{\circ} \mathrm{C}$ using the following multisteps protocol shown in Table 1:

Table 1. Multisteps protocol for isoelectric focusing of IPG strips

\begin{tabular}{ll}
\hline Method & Linear \\
Rehydration & Passive \\
Run Temperature & $20{ }^{\circ} \mathrm{C}$ \\
IPG Strip & $\mathrm{pH} 3 \sim 10,17 \mathrm{~cm}$ \\
Step 1 & $500 \mathrm{~V}$ Ramp: Time: 01:00 hour \\
Step 2 & 1,000 V Ramp: Time: 01:00 hour \\
Step 3 & 8,000 V Ramp: V hour: 32,000 V \\
Step 4 & $500 \mathrm{~V}$ Hold Time: 10:00 hours \\
Focusing current & $50 \mu \mathrm{A} /$ strip
\end{tabular}

After the first dimension, individual strip was equilibrated in $6 \mathrm{M}$ urea, $30 \% \mathrm{v} / \mathrm{v}$ glycerol, $2 \% \mathrm{w} / \mathrm{v}$ SDS, $0.05 \mathrm{M}$ Tris-HCl, $\mathrm{pH} 8.8$, and $15 \mathrm{mM}$ DTT for 20 minutes. An additional incubation in the same buffer supplemented with iodoacetamide $400 \mathrm{mg} / \mathrm{mL}$ was carried out for another 20 minutes. The second dimension was performed overnight at $120 \mathrm{~V}$ 
using a homogeneous polyacrylamide gel (12\% T, $200 \mathrm{~mm}$ x $230 \mathrm{~mm} \times 1.5 \mathrm{~mm})$ and applying continuous Laemmli buffer system (Laemmli, 1970).

\subsection{PROTEIN VISUALIZATION AND IMAGE ANALYSIS}

CyDyes labelled protein gels were scanned using a Fuji film FLA-5100 series imager (Fuji Photo, Kanagawa, Japan). The excitation and emission wavelengths are shown in Table 2. Silver staining was performed using a method described by Morrissey (Morrissey, 1981). Colloidal Coomassie staining was performed according to Neuhoff and their colleagues (Neuhoff et al., 1988).

Table 2. Excitation and emission wavelengths used for imaging of fluorochrome labelled gels

Bandwidths of the filters are shown in red and green colour

\section{FLA 5100 Series Imager}

\section{Excitation filter (nm) $\quad$ Emission filter (nm)}

$\begin{array}{lll}\text { Cy3 } & 532 & \text { Long pass } 575 \\ \text { Cy5 } & 635 & \text { Long pass } 665\end{array}$

Fluorescent images were acquired in 16-bit TIFF files format and analysed by Delta2D software (Version 3.4; Decodon, Greifswald, Germany). For Coomassie and silver staining, digital images were obtained using Fuji film FLA-5100 series imager (Fuji Photo, Kanagawa, Japan). An image analysis was performed by Delta2D software (Decodon, Greifswald, Germany) and statistical analysis of protein variations was carried out using the Student's $t$-test and statistical significance was assumed for p-values less than 0.05 . 


\subsection{IN-GEL DIGESTION AND MALDI-TOF MS ANALYSIS OF PROTEIN} SPOTS

To permit identification of differentially expressed proteins from the saturation labeled gels, Coomassie brilliant blue or silver stained gels were performed. Differentially expressed protein spots were manually excised from the gels and washed with distilled water for 15 minutes. The destaining procedure for Coomassie stained protein spots was carried out with $50 \% \mathrm{v} / \mathrm{v}$ acetonitrile (ACN) and $100 \mathrm{mM}$ ammonium bicarbonate for 5 minutes. For silver stained protein spots, destaining procedure was performed as described by Gharahdaghi et al., 1999. After destaining, in-gel digestion was performed with trypsin and the resulting peptide mixture was extracted with various concentrations of ACN and trifluoroacetic acid (TFA). Extracted peptide mixture was further dissolved in TFA and co-crystallised with 2, 5-dihydroxy-benzoic acid (matrix) on a stainless steel target using $1 \mu \mathrm{L}$ matrix and $1 \mu \mathrm{L}$ sample. An Applied Biosystems Voyager-DE STR time-of-flight mass spectrometer, operating in delayed reflector mode with an accelerated voltage of $20 \mathrm{kV}$ was used to generate peptide mass map. Indiviual peptide mass map was obtained by averaging 50 individual laser shots. Obtained peptide masses were externally calibrated with a peptide mix of des-Arg-bradykinin $\left([\mathrm{M}+\mathrm{H}]^{+} 904.46\right)$, angiotensin I $\left[(\mathrm{M}+\mathrm{H}){ }^{+}\right.$1296.68, Glu1-fibrinopeptide B $(\mathrm{M}+\mathrm{H})^{+}$1570.67, АCTH $(1-17)(\mathrm{M}+\mathrm{H})^{+}$ 2093.08, ACTH (18-39) $(\mathrm{M}+\mathrm{H})^{+}$2465.19] and produced to search against protein sequences database.

\subsection{PEPTIDE SEQUENCE ANALYSIS}

To confirm the data obtained from mass finger print analyses, all samples were subjected to peptide sequence analyses. After in-gel digestion, extracted peptide mixture was dissolved in $0.1 \%$ formic acid (FA). One $\mu \mathrm{L}$ of sample was introduced using a CapLC 
auto sampler (Waters) onto a $\mu$-precolumn ${ }^{\mathrm{TM}}$ Cartridge $\mathrm{C} 18$ pepMap $(300 \mu \mathrm{m}$ x $5 \mathrm{~mm}$; $5 \mu \mathrm{m}$ particle size) and separated through a C18 pepMap100 nano Series ${ }^{\mathrm{TM}}(75 \mu \mathrm{m} \mathrm{x}$ $15 \mathrm{~cm} ; 3 \mu \mathrm{m}$ particle size) analytical column (LC Packing, Amsterdam, Netherlands). The mobile phase consisted of solution-A containing $5 \% \mathrm{ACN}$ in $0.1 \% \mathrm{FA}$ and solution $\mathrm{B}$ (95\% ACN in $0.1 \% \mathrm{FA}$ ). Total sample run time was 60 minutes per sample analysis. Initially, samples were injected into a precolumn and washed with $0.1 \%$ formic acid (30 $\mu \mathrm{L})$ for 5 minutes. The washing step was followed by an elution step with an exponential gradient starting with $10 \%$ and ending with $95 \%$ solution $\mathrm{B}$. The flow rate was decreased by a flow splitter from $5 \mu \mathrm{L} / \mathrm{min}$ pump to $0.25 \mathrm{~nL} / \mathrm{min}$. The precolumn was re-equilibrated with $0.1 \% \mathrm{FA}(20 \mu \mathrm{L} / \mathrm{min})$ for another 5 minutes. The nanospray needle was held at $2 \mathrm{kV}$ and the source temperature was at $40^{\circ} \mathrm{C}$. After chromatographic separation, peptide sequencing was performed on a Q-TOF Ultima Global (Micromass, Manchester, UK) mass spectrometer equipped with a nanoflow ESI Z-spray source in positive ion mode. Multiple charged peptide parent ions were automatically marked, selected in the quadruple fragmented in the hexapole collision cell and their fragment patterns were analysed by time of flight. The data acquisition was performed using MassLynx (v 4.0) software on a Windows NT PC, while data were further processed on a Protein-Lynx-Global-Server (v 2.1), (Micromass, Manchester, UK).

\subsection{DATABASE SEARCH AND PROTEIN IDENTIFICATION}

The raw data files were deconvoluted and deisotoped using Max Ent ${ }^{\mathrm{TM}}$ lite algorithm. This file format was further produced to search against Swissprot database 50.5 (230150 sequences, 84479584 residues) through the web based Mascot search engine (MASCOT 2.1) using following parameters: trypsin as an enzyme, monoisotopic, 1 possible missed cleavage, a peptide mass tolerance of $100 \mathrm{ppm}$, fragment mass tolerance of 0.6 Da and carbamidomethyl and methionine oxidation were considered as variable modifications 
(Oxford, UK, http://www.matrixscience.com.search_form_select.html) (Perkins et al., 1999). Results were scored using Probability Based Mowse Score (Protein score is $-10^{*} \log (\mathrm{p})$, where $\mathrm{p}$ is the probability that the observed match is a random event. Individual ions scores $>26$ indicate identity or extensive homology $(p<0.05)$. Only proteins with a minimum of one peptide identified and a protein score are $>26$ in the peptide summary report were included in the protein identification list.

\subsection{WESTERN BLOT ANALYSIS}

Validation of our proteomic data (for proteins of interest) was performed by Western blot analyses (Burnette, 1981). After SDS-PAGE, blotting was performed on nitrocellulose membrane (Amersham Pharmacia Biotech, Buckinghamshire, UK) at $250 \mathrm{~mA}$ for 24 hours in transfer buffer $(25 \mathrm{mM}$ Tris- $\mathrm{HCl}, \mathrm{pH} 8.4,192 \mathrm{mM}$ glycine, $0.5 \% \mathrm{w} / \mathrm{v}$ SDS, $20 \% \mathrm{v} / \mathrm{v}$ methanol). The membranes were blocked in $5 \% \mathrm{w} / \mathrm{v}$ non-fat dry milk in PBS containing $0.1 \% \mathrm{v} / \mathrm{v}$ Tween-20 for 2 hours at $37{ }^{\circ} \mathrm{C}$. The incubations with the following primary antibodies mouse anti-PDIA3 polyclonal antibody (Stressgen, Victoria, Canada), rabbit anti-PDIA4 polyclonal antibody (Stressgen, Victoria, Canada), mouse anti-ACTB monoclonal antibody, rabbit anti-HSPA5 polyclonal antibody (Sigma-Aldrich, Missouri, USA), mouse anti-CALR monoclonal antibody (BD Bioscience, Rockville, USA), rabbit anti-NF-אB subunit p65 monoclonal antibody (Santa Cruz, CA, USA) and mouse antiTPI polyclonal antibody (Abnova, Taiwan, China) were carried out for 1 hour at $37^{\circ} \mathrm{C}$. After washing, membranes were incubated with 1:1200 dilution of horseradish peroxidase-conjugated sheep anti-mouse antibody or 1:12000 horseradish peroxidaseconjugated donkey anti-rabbit antibody (Amersham Biosciences, Freiburg, Germany) for another 60 minutes at $37^{\circ} \mathrm{C}$. To visualize the protein bands, nitrocellulose membranes were washed with PBS containing $0.1 \% \mathrm{v} / \mathrm{v}$ Tween-20 and treated with Western blotting luminal reagent (Perkin Elmer, Boston, USA). Finally, results were obtained on a Kodak 
film and quantified by densitometry using the Multi Analyst Software (Bio-Rad Laboratories, CA, USA).

\subsection{PYRUVATE KINASE ACTIVITY ASSAY}

Pyruvate kinase activity assay was assessed by continuous spectrometric rate determination method as described by Ainsworth et al. (Ainsworth and MacFarlane, 1973). HL-60 and A498 cells were grown in $75 \mathrm{~cm}^{2}$ culture flasks at the cell density of $5 \times 10^{7}$ cells $/ \mathrm{mL}$ in the corresponding medium. Cells were trypsinized and centrifuged at $200 \mathrm{x}$ g for 10 minutes at $4{ }^{\circ} \mathrm{C}$. Obtained cell pellets were disrupted by vortexing in assay buffer $\left(100 \mathrm{mM}\right.$ potassium phosphate buffer, $\mathrm{pH} 7.6$ at $\left.37^{\circ} \mathrm{C}\right)$ with addition of an equal volume of glass beads. For removing cell debris, cell lysates were centrifuged twice at $4500 \mathrm{x}$ g for 10 minutes at $4{ }^{\circ} \mathrm{C}$. Supernatants were used directly for enzymatic assay. An aliquot of supernatant from the disrupted cells was added to a solution containing $39 \mathrm{mM}$ potassium phosphate, $0.58 \mathrm{mM}$ phospho (enol) pyruvate, $0.11 \mathrm{mM} \mathrm{NADH}, 6.8 \mathrm{mM}$ magnesium sulphate, $1.5 \mathrm{mM}$ ADP, and 10 units of lactate dehydrogenase. Activity was determined through Lambda 25 UV/VIS Spectrophotometer (Perkin Elmer Life Sciences, Rodgau-Jügesheim, Germany) at the rate of absorbance decrease $340 \mathrm{~nm}$ with 1 unit corresponding to the oxidation of 1 pmol of NADH per minute at $37{ }^{\circ} \mathrm{C}$.

\subsection{ANALYSIS OF MITOCHONDRIA MEMBRANES POTENTIAL}

Mitochondrial membrane potential $\left(\Delta \psi_{\mathrm{m}}\right)$ is measured in intact cell by loading the cytosol or the mitochondrial matrix with calcein, a hydrophilic $620 \mathrm{Da}$ fluorochrome that normally does not cross the inner membrane (Kroemer et al., 1998; Bernardi et al., 1999). Alternatively, $\Delta \psi_{\mathrm{m}}$ can be assessed indirectly using a fluorochrome 5,5',6,6'-tetrachloro1,1',3,3'-tetraethyl-benzimidazolcarbocyanine iodide (JC-1). JC-1 (Invitrogen, Karlsruhe, Germany), a cationic dye that indicates mitochondrial polarization by shifting its 
fluorescence emission from green $(\sim 525 \mathrm{~nm})$ to red $(\sim 590 \mathrm{~nm})$ (Smiley et al., 1991). Untreated and MTX treated cells were resuspended in $1 \mathrm{~mL}$ culture medium, stained with a final concentration of $10 \mu \mathrm{g} / \mathrm{mL} \mathrm{JC}-1$ and incubated for $10 \mathrm{~min}$ at $37^{\circ} \mathrm{C}$. The elimination of unbound dye was carried out by washing the cells twice with culture media and immediately quantified by FACSCalibur Flow Cytometer (BD Biosciences, Rockville, USA). Cells in which the $\Delta \psi_{\mathrm{m}}$ was maintained accumulate so-called Jaggregates indicated by the red fluorescence, whereas those with a collapsed $\Delta \psi_{\mathrm{m}}$ shown green fluorescence. Data analyses were performed by Cell Quest software that works under Windows 3.1 or Windows 95, i.e. WinMDI (written by Dr. Joe Trotter, Scripps Research Institute, La Jolla, CA, USA).

\subsection{DETECTION OF ROS}

Reactive oxygen species (ROS) formation was quantified by staining with dihydrorhodamine 123 (DH-123, Sigma-Aldrich Chemie GmbH, Steinheim, Germany), a cell-permeable non-fluorescent compound that is oxidized by cellular peroxides to fluorescent rhodamine (Dugan et al., 1995). Untreated and MTX treated A498 cells were resuspended in $5 \mathrm{~mL}$ culture medium, stained with $500 \mu \mathrm{M}$ DH-123 and incubated for 2 hours at $37^{\circ} \mathrm{C}$. After washing cells with culture medium, fluorescence images (Zeiss Axiovert 100 TV) were obtained using appropriate excitation and emission wavelengths. Images were captured immediately after illumination (25 msec exposure). Photomicrograph of random $40 \mathrm{x}$ field was analysed using Analysis Doku ${ }^{(\mathrm{R})}$ software (Soft imagine systems, Muenster, Germany). 
MTX dose dependent response curves were obtained by non-linear regression analysis using the software Sigma Plot 8.0 (SYSTAT software, Chicago, Illinois). The data were fitted to the sigmoid $\mathrm{E}_{\max }$ model as described by (Bourgeois, 1988).

$$
E_{\text {drug }}=E_{\min }+\frac{E_{\max }-E_{\min }}{1+\left[\operatorname{dose} / \mathrm{TD}_{50}\right]^{\text {Hill }}}
$$

$E_{\text {drug }}$ is the measured effect of the drug at a certain dose. $E_{\text {drug }}$ starts at $E_{\max }$ and goes to $\mathrm{E}_{\min }$ with a sigmoid shape. Note that $\mathrm{TD}_{60}$ in our experiment indicates the dose that gives sixty-percentile maximal effect. Results are shown as means \pm S.D. of three independent experiments. All the results were tested for significant differences by paired, one tailed, Student's $t$-test. 


\section{RESULTS}

APL cells serve as a paradigmatic cell model in biological and clinical leukaemic research. Several cell lines have been derived from APL patients. Some of these cell lines such as HL-60, NB-4 and PL-21 are most commonly used in leukaemic research. Especially, the HL-60 cell line has attracted the most leukaemic research interest. Its capacity to differentiate in vitro to a variety of different cell types of the myelomonocytic lineage is the characteristic feature of HL-60 cells. Therefore, studies with HL-60 cells have been proved to be invaluable in various areas, which include the following:

1. Providing insights into the control of mechanisms of normal granulocytes /monocytes/macrophage differentiation.

2. Suggesting an unique in-vitro model for studying the cellular and molecular events involved in the proliferation and differentiation of APL against various chemotherapeutic agents.

3. Serving as an valuable model for studying the specific cellular oncogene expression in relationship to particular haematopoietic differentiative lineage (Collins, 1987; Birnie, 1988).

\subsection{MTX DEMONSTRATES CELL TOXICITY ON HL-60 CELLS}

To elucidate the effect of MTX on HL-60 cells, we treated these cells with increasing concentrations of MTX ( 0 to $11 \mu \mathrm{M})$ for $0,24,48$, and 72 hours. Trypan blue exclusion assay showed a progressive decrease in cell viability with increasing concentrations of MTX for the indicated time periods (Figure 6). Minimum cell viability was obtained after exposing HL-60 cells to $11 \mu \mathrm{M}$ MTX for 72 hours. The MTX concentration that led to a $60 \%$ mean reduction of cell viability $\left(\mathrm{IC}_{60}\right)$ was calculated and found to be $2.5 \mu \mathrm{M}$. This concentration of MTX was further used in following experiments. 


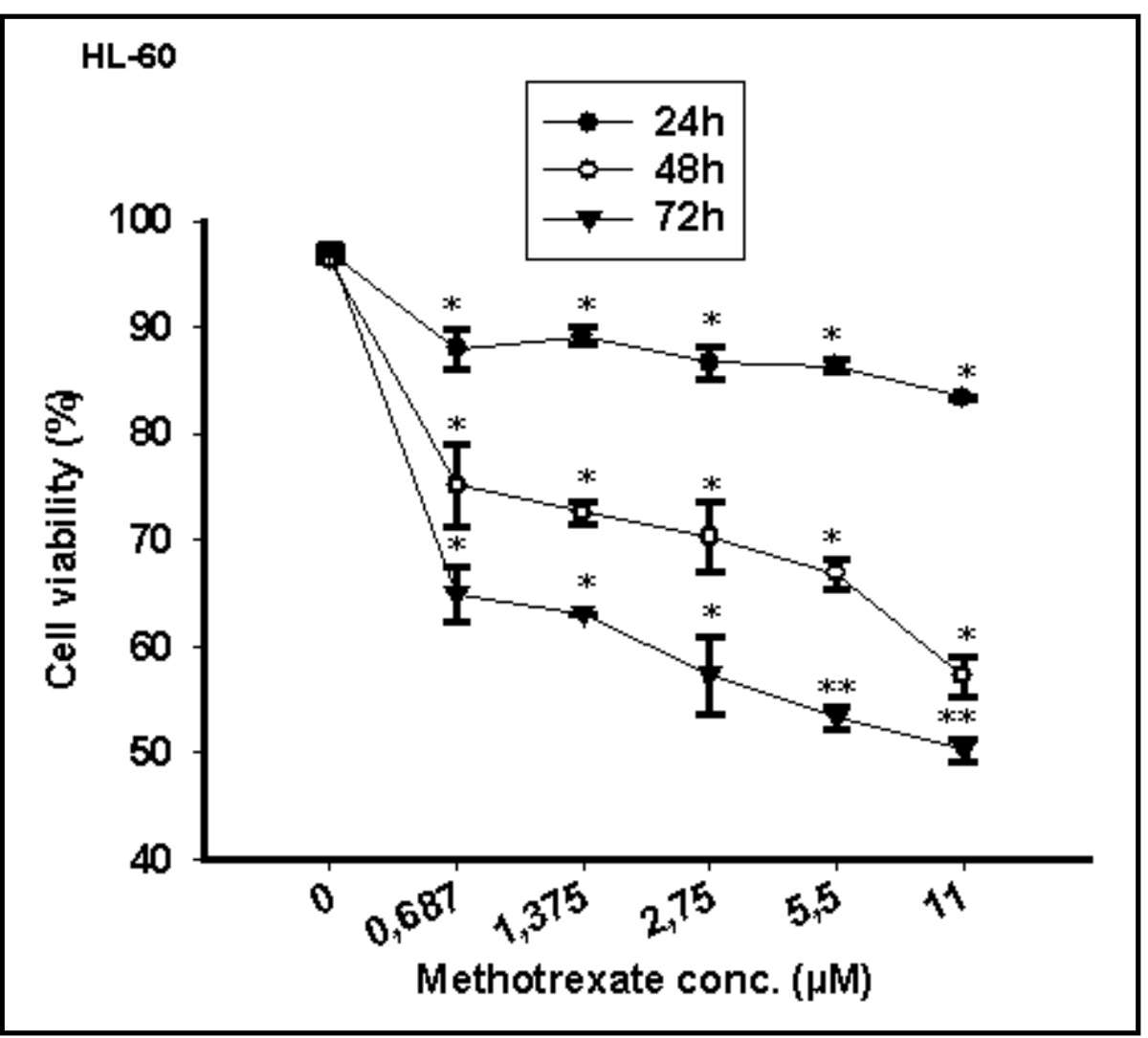

\section{Figure 6. Impact of MTX on HL-60 cells}

HL-60 cells were treated with wide range of MTX concentrations ( 0.0 to $11 \mu \mathrm{M})$ for 24 , 48 and 72 hours. Cell viability was determined by standard trypan blue exclusion assay at above-mentioned time periods and presented as percentage in Y-axis. Results are given as the mean values \pm S.D. of $\%$ cell viability from three independent experiments. $* \mathrm{p}<0.05, * * \mathrm{p}<0.001$.

\subsection{MTX INDUCES APOPTOSIS IN HL-60 AND A498 CELLS}

To address the question, whether the initial cell death observed in MTX treated HL-60 cells was due to apoptosis or necrosis, we investigated the morphological features of HL-60 cells during the exposure to MTX using normal light microscopy and flow cytometry. Several investigators have previously shown that cells undergoing apoptosis have decrease in forward light scatter and increase in side light scatter depicting loss of cell volume and increase in cell granularity, respectively (Dive and Hickman, 1991; 
Nicoletti et al., 1991; Zamai et al., 1993). Our microscopic and flow cytometric analysis in HL-60 cells revealed the same cell shrinkage and induction of cellular granularity after addition of $2.5 \mu \mathrm{M}$ MTX for 72 hours (Figure 7A\&B).

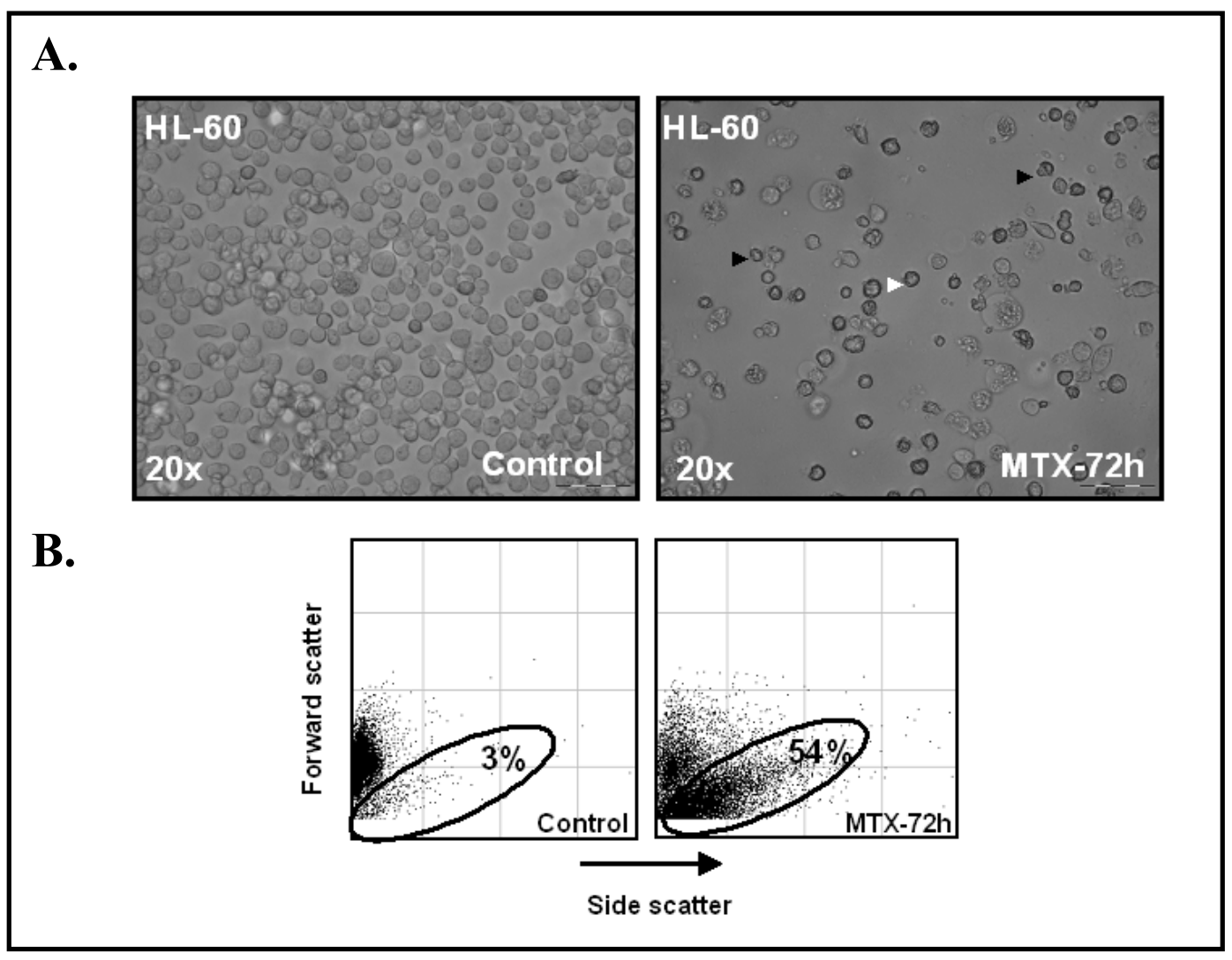

Figure 7. Morphological changes observed in HL-60 cells after MTX treatment

HL-60 cells were incubated without or with $2.5 \mu \mathrm{M}$ MTX in RPMI medium for 72 hours and morphological changes were observed using: (A) Normal light microscopy. Apoptotic cells are shown in upper right panel and depict by black and white arrows. The photograph was documented at an exposure of 20x magnification. (B) Flow cytometry. Results are plotted as forward scatter (FSC) against side scatter (SSC). Increased cellular granularity (\%) is shown inside the marked oval circle (lower panels).

We further confirmed our preliminary apoptotic observations by PtdSer exposure. Exposure of PtdSer in untreated and MTX treated HL-60 cells were measured using FITC-labelled-annexin-V staining assay as described in the Experimental Procedures. An increase in the percentage of apoptotic cells having PtdSer exposure was detected in MTX treated HL-60 cells. When these cells were treated with $2.5 \mu \mathrm{M}$ of MTX, $40 \%$ of the 
cells showed an increase in translocation of PtdSer at the plasma membrane as compared to untreated cells (Figure 8A). To establish whether other cancer cells show MTX induced PtdSer exposure, we investigated the effect of MTX on A498 cells. MTX resulted in differential degree of PtdSer exposure in A498 cells (Figure 8A). Moreover, both PtdSer translocation and cell membrane permeability (trypan blue positive cells) occurred simultaneously in MTX treated HL-60 cells. This was illustrated by plotting the percentages of cells having undergone PtdSer translocation and cell permeability in HL-60 cells on the same graph (Figure 8B). 
A. HL-60
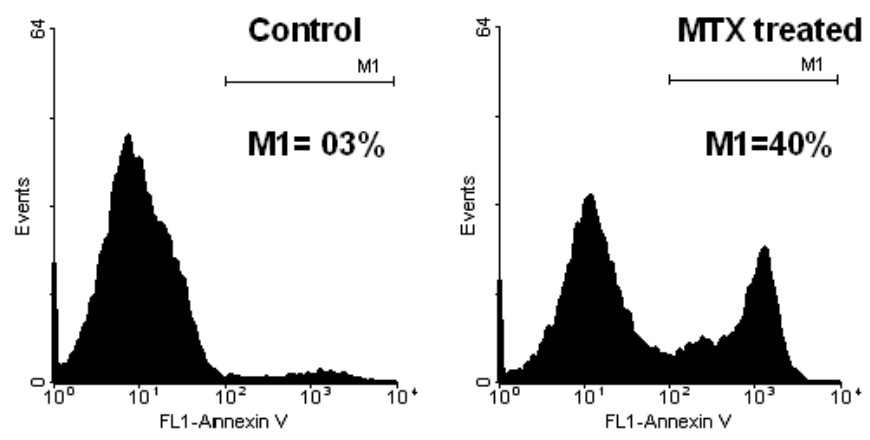

A498
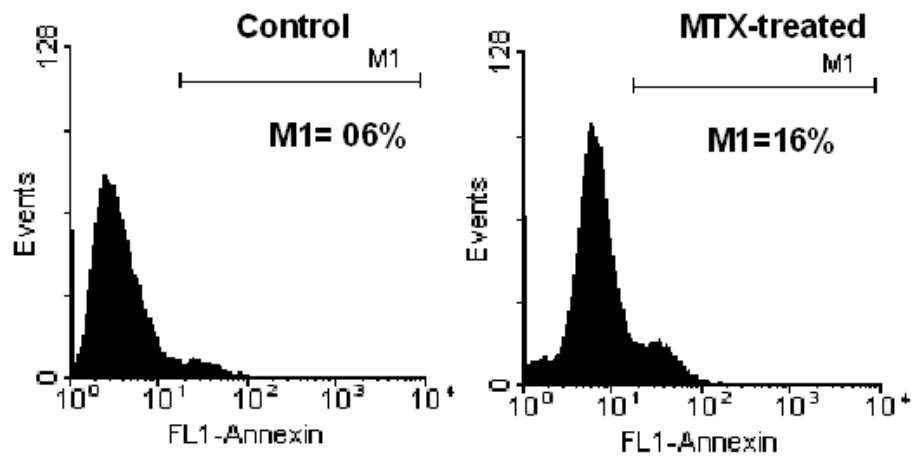

B.

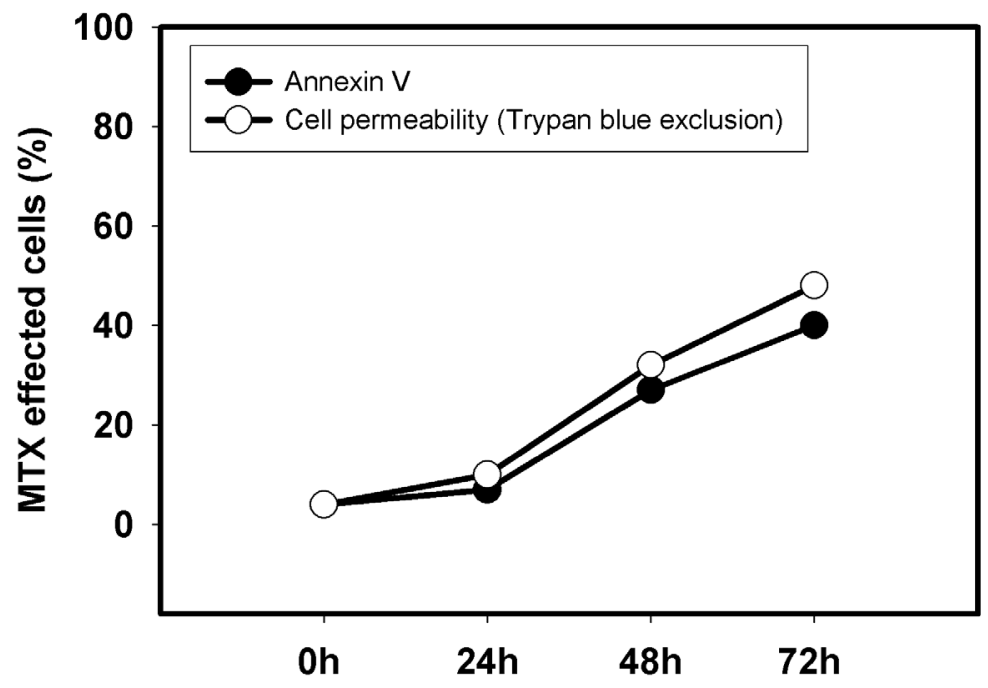

Figure 8. Assessment of apoptosis by FITC-labelled-annexin-V staining assay

HL-60 and A498 cells were incubated with or without $2.5 \mu \mathrm{M}$ and $45 \mu \mathrm{M}$ MTX respectively for 72 hours, stained with FITC-labelled-annexin-V and analysed by flow cytometry. (A) MTX induces PtdSer exposure. Numbers above the histogram markers indicate the percentage of apoptotic cells in a representative experiment. Similar results were obtained in two additional experiments with different passages of cells. (B) Percentage of MTX affected HL-60 cells having translocated PtdSer (annexin V positive cells) and died (trypan blue positive) cells shown in Y-axis as a function of the indicated time periods (X-axis), obtained by replotting the data on the same illustration. 
To determine the sequence of apoptotic events, we replotted MTX treated HL-60 cell data ( $\Delta \psi_{\mathrm{m}}$, cell morphology and PtdSer exposure) in the same graph. In HL-60 cells, cell shrinkage, PtdSer exposure and induction of cellular granularity induced by MTX were preceded by the loss of $\Delta \psi_{\mathrm{m}}$. HL-60 cells exhibited a reduction in the $\Delta \psi_{\mathrm{m}}$ at 24 hours after MTX treatment, whereas at this time point no loss of cell shrinkage has occurred and neither translocation of PtdSer nor induction of cellular granularity were detected; yet $\Delta \psi_{\mathrm{m}}$ was already perturbed (Figure 9).

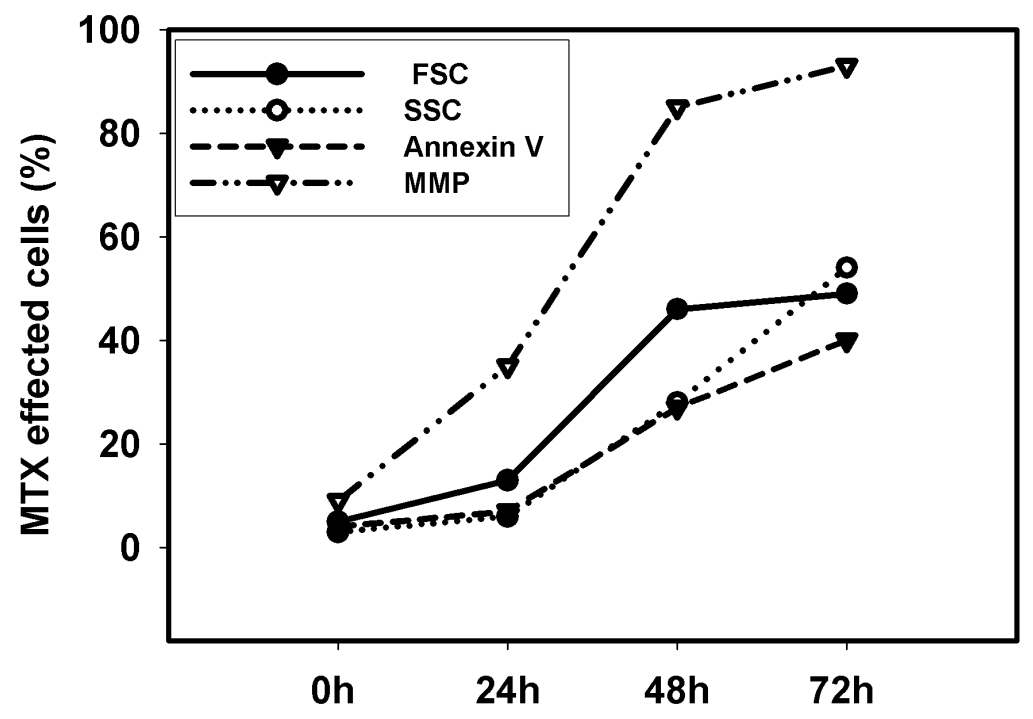

Figure 9. Morphological events of apoptosis examined by flow cytometry

HL-60 cells were incubated without or with $2.5 \mu \mathrm{M}$ MTX in RPMI medium for 24, 48 and 72 hours. $\Delta \psi_{\mathrm{m}}$ disruption (MMP), cell shrinkage (FSC), cell granularity (SSC) and translocation of PtdSer at the cell surface (FITC-labelled-annexin-V) were evaluated by flow cytometry (described in the Experimental Procedures) as a function of the indicated time periods (X-axis). These morphological events of apoptosis were observed by replotting the obtained data in the same graph. 


\subsection{EVALUATING EXPERIMENTAL REPRODUCIBILITY OF THE}

\section{CYSTEINE LABELLED IN-GEL ELECTROPHORESIS APPROACH}

To characterize the molecular targets of MTX induced apoptosis in the analysed cancer cell lines, we performed cysteine labelled differential in-gel electrophoresis approach. In this approach, a new set of cysteine labelled CyDyes has been used for labelling protein samples. Wide dynamic wavelength, high sensitivity and reproducibility (Shaw et al., 2003) appeared to make these dyes suitable to identify intracellular protein changes involved in MTX induced apoptosis. Moreover, these dyes enable to visualize large scale protein expression profile from small amounts of protein samples such as those obtain from laser-micro dissected tissues (Kondo et al., 2003) and primary cultured hepatocytes (Fujii et al., 2005). In addition to this, cysteine labelling CyDyes have been successfully implicated in the proteomic study of adenoma of Min mice (Kondo et al., 2003), hepatocellular carcinoma tissue (Fujii et al., 2005), haematopoietic cells (Evans et al., 2004), and identifying free thiols from native protein extract of seeds (Maeda et al., 2004).

To control the CyDyes labelling artifacts, we compared CyDyes labelled protein spots profile with traditional silver stain. Although, the overall protein spots pattern between the silver staining and CyDyes labelled was quite similar, yet subtle differences were detected. These differences in the protein spots were probably dependent on the high/low abundance of cysteine residues in the proteins. For example, some proteins such as fructose-bisphosphate aldolase A (ALDOA) and ATP synthase subunit $\alpha$ (ATP5A1) on the silver stain gels consistently showed reduce labelling intensity on the Cy5 labelled gel image section in MTX treated HL-60 cells (Figure 10). This has been a criticism of cysteine-modifying fluorophores (Berggren et al., 2001), when used for global proteomic 
studies. In spite of this drawback, the cysteine labelling CyDyes still offer promising advantages over other conventional protein detection techniques.
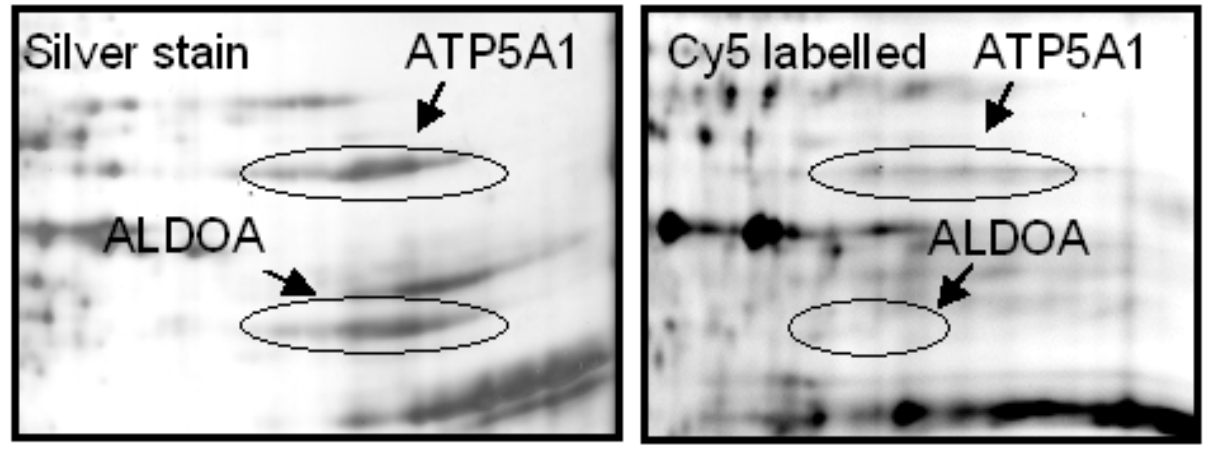

Figure 10. Partial view of two-dimensional gel electrophoresis; gels obtained from MTX treated HL-60 cell lysates visualised by silver stain or Cy5 dye

$2.5 \mu \mathrm{M}$ MTX treated samples were prepared, resolved on two-dimensional gel electrophoresis and visualised by silver staining or Cy5 labelled as described in the Experimental Procedures. The type of protein detection technique is indicated in the top right corner of each gel image section. Marked arrows and circles depict visible protein spots in silver stained HL-60 cells as compared to Cy5 labelled gel image section. Labelling of the spots correspond to the genes name as assigned in Table 4.

In order to evaluate the experimental reproducibility of cysteine labelled two-dimensional gel spot profiles, four independent untreated samples of HL-60 cell lysates were labelled with Cy3 dye. Cysteine labelled differential in-gel electrophoresis was performed as described in the Experimental Procedures. After analysing the gels with Delta 2D software, approximately 500 spots from a well-resolved area of the gels were selected (those spots could be matched on all control gels) and quantified the protein spot $\%$ volume data by Delta 2D software. The resulted data were plotted on a log scale in both axis and correlation coefficients were calculated for the data sets using Sigma Stat version 8 . We observed a good experimental reproducibility by comparing of the different gel images with correlation coefficients between $0.74-0.92$ (Figure 11) confirming that 
consistent protein profiles could be obtained using cysteine labelled differential in-gel electrophoresis.

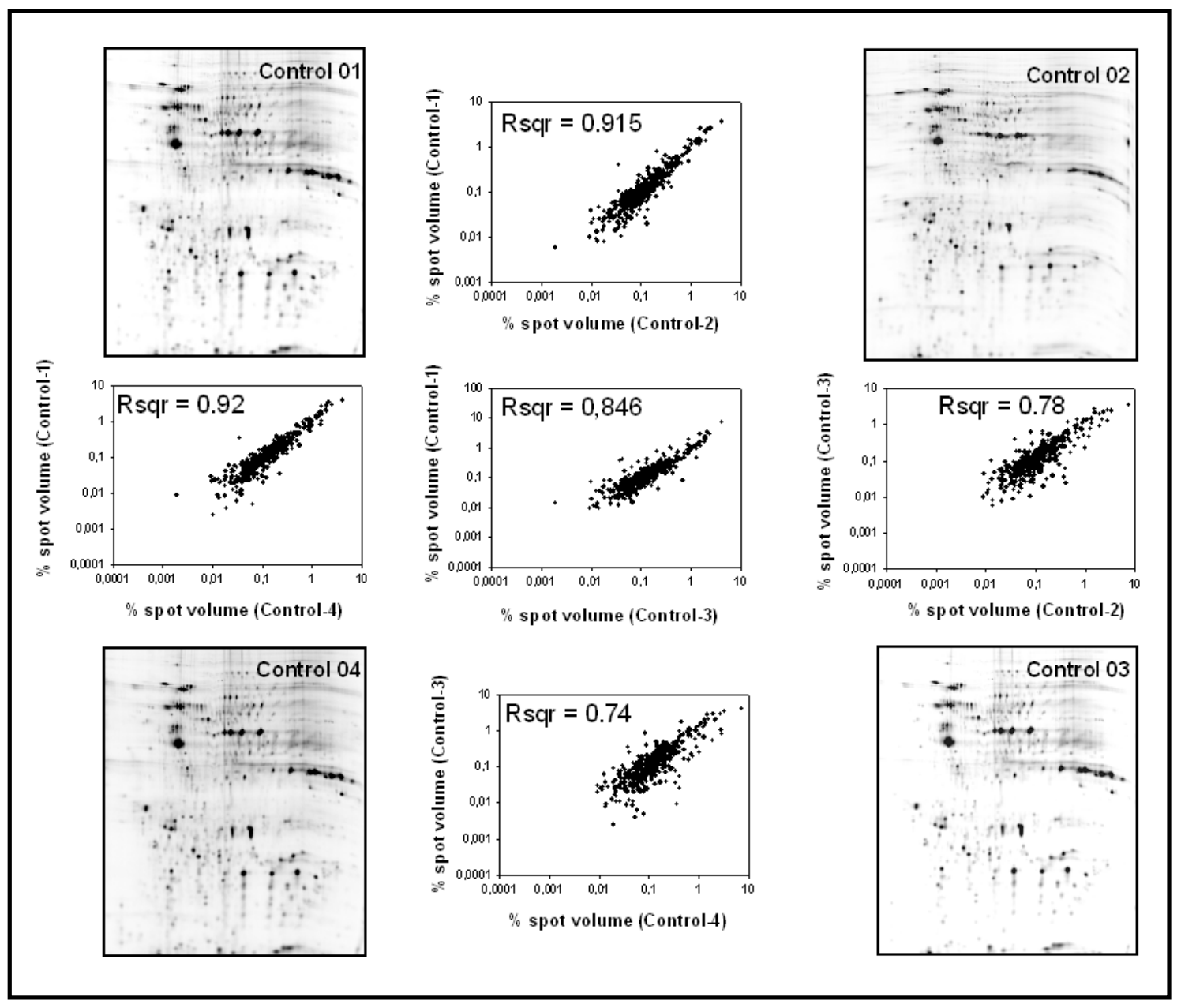

Figure 11. Evaluation of experimental reproducibility by Scatter Plot analysis

Scatter plots analysis of four independent untreated (control) samples of HL-60 cell lysates were labelled with $\mathrm{Cy} 3$ dye and resolved on two-dimensional gels as described in the Experimental Procedures. Cy3 labelled control gels were analysed with Delta 2D software. Approximately 500 protein spots from a well-resolved area of the gels were selected, quantified and plotted on a log scale in both axis. Correlation coefficient (Rsqr) was further calculated for each paired protein data set of two control sample lysates and shown in above-mentioned figure. 


\subsection{IDENTIFICATION OF DIFFERENTIALLY EXPRESSED PROTEINS} IN MTX TREATED HL-60 CELLS

After establishing the protocol in a reproducible manner, we prepared three independent sets of protein cell lysates from untreated and $2.5 \mu \mathrm{M}$ MTX treated HL-60 cells obtained after 72 hours. Each set of cell lysate was labelled with Cy3 and Cy5 dyes, respectively. The corresponding $\mathrm{Cy} 3$ and $\mathrm{Cy} 5$ labelled samples were mixed and co-resolved on the two-dimensional gel electrophoresis (as described in the Experimental Procedures), to achieve high accuracy for the protein quantification. Figure 12 represents an example of large dual colour two-dimensional image of HL-60 cell proteome obtained from untreated and MTX treated HL-60 cell lysates labelled with CyDyes. Cy3 labelled proteins are shown in green colour (represent untreated HL-60 cell proteome) and Cy5 labelled proteins are in red colour (represent $2.5 \mu \mathrm{M}$ MTX treated HL-60 cell proteome). 845 and 878 protein spots were detected by Delta $2 \mathrm{D}$ software in untreated and $2.5 \mu \mathrm{M}$ MTX treated samples, respectively. Significant differences in the proteins expression were found in the untreated and MTX treated samples as shown in Table 3. Although, we found more than 800 paired overall protein spots in the different sample sets, 492 protein spots were present in all the three sets of untreated and MTX treated gels. Therefore, we included 492 protein spots in the differential proteome analysis of untreated and MTX treated HL-60 cells to achieve statistical confidence. Altogether, 230 protein spots were almost equally abundant in both cell proteomes leading to the yellow colour overlay. 81 protein spots were differentially expressed $(\mathrm{p}<0.05)$ in the MTX treated HL-60 cell proteome. We considered significant all the quantitative differences with a variation of at least three times in \% spot volume data with the Student's $t$-test statistical probability less than $0.05(\mathrm{p}<0.05)$. Using Q-TOF Ultima Global (Micromass, Manchester, UK) equipped with a nanoflow ESI Z-spray and an Applied Biosystems Voyager-DE STR 
time-of-flight mass spectrometer, we identified 24 differentially expressed proteins from MTX treated HL-60 cell proteome having different biological functions. Table 4 shows the list of the proteins identified by database search, which are arranged according to their respective role in metabolic or signalling pathways. It could be precluded that the detection limits of the applied mass spectrometry would limit the identification of proteins of the less-intense spots. 


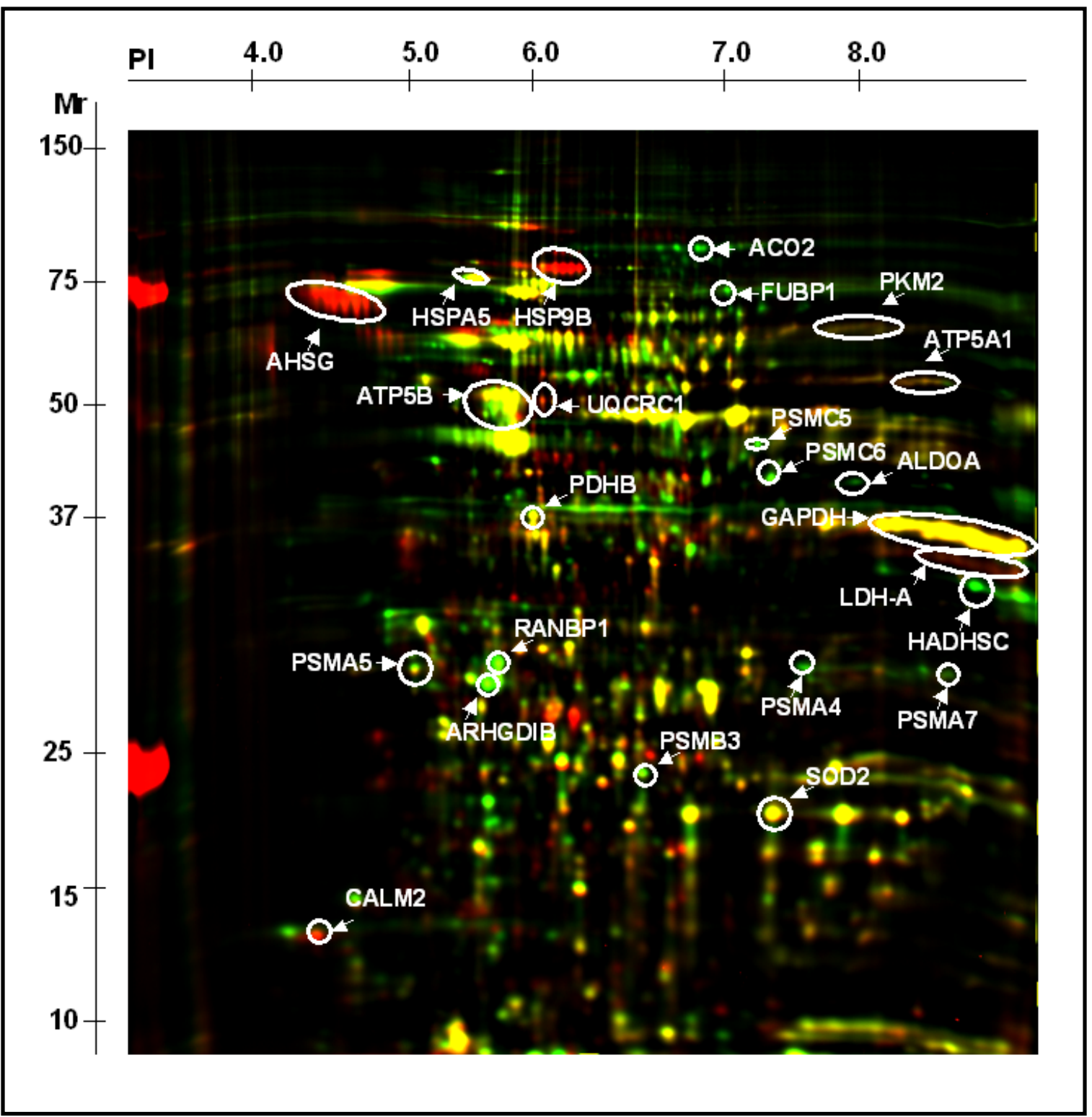

Figure 12. Large dual colour two-dimensional image of proteins expression profile obtained from untreated and MTX treated HL-60 cell lysates labelled with corresponding CyDyes

HL-60 cells were incubated without or with $2.5 \mu \mathrm{M}$ MTX in RPMI medium for 72 hours. Cysteine labelled differential in-gel electrophoresis was performed using CyDyes as described in the Experimental Procedures. Differentially expressed protein spots were excised out. After in-gel digestion with trypsin, extracted peptide mixture was analysed by mass spectrometry and identified by database search. Cy3 labelled proteins are shown in green colour (represent untreated HL-60 cell proteome) and Cy5 labelled proteins are in red colour (represent $2.5 \mu \mathrm{M}$ MTX treated HL-60 cell proteome). Arrow marked spots are the differentially expressed proteins obtained after 72 hours MTX treatment. Labelling of the spots correspond to the genes name as assigned in Table 4. 


\section{Table 3. Summary of untreated and MTX treated HL-60 proteome analysed by Delta 2D software}

Number of protein spots detected in the control HL-60 proteome

Number of protein spots detected in the MTX treated HL-60 proteome

Number of protein spots matched in all gels

Number of high abundant protein spots in MTX treated HL-60 proteome (fold change more than 5.0)

Number of up regulated protein spots in MTX treated HL-60 proteome (fold change 1.5-5.0)

Number of low abundant protein spots in MTX treated HL-60 proteome (fold change less than 0.5)

Number of down regulated protein spots in MTX treated HL-60 proteome (fold change 0.3-0.5) 
Table 4. List of the proteins that were differentially expressed in HL-60 cells during treatment with $2.5 \mu M$ MTX for 72 hours

\begin{tabular}{|c|c|c|c|c|c|c|}
\hline Abbreviation & Swiss Prot (Acc. No.) & Name of protein & Molecular weight (Da) & $p I$ value & No. of peptide matched $* *$ & MS Score* $\S$ \\
\hline \multicolumn{7}{|c|}{ Endoplasmic Reticulum Chaperones } \\
\hline${ }^{\mathrm{S}} \mathrm{CALR}$ & P27797 & Calreticulin precursor & 48112 & 4.3 & 3 & 89 \\
\hline HSPA5 & P11021 & $78 \mathrm{kDa}$ Glucose regulated protein precursor & 72288 & 5.0 & 23 & 989 \\
\hline \multicolumn{7}{|c|}{ Proteasome Complex subunits } \\
\hline PSMA4 & $\mathrm{P} 25789$ & Proteasome subunit alpha type 4 & 29465 & 7.2 & 9 & 236 \\
\hline PSMA5 & P28066 & Proteasome subunit alpha type 5 & 26394 & 4.8 & 8 & 274 \\
\hline PSMA7 & o14818 & Proteasome subunit alpha type 7 & 27870 & 7.8 & 6 & 255 \\
\hline PSMB3 & P49720 & Proteasome subunit beta type 3 & 22933 & 5.9 & 7 & 215 \\
\hline PSMC5 & P62195 & 26S Protease regulatory subunit 8 (p45/SUG) & 45597 & 7.1 & 9 & 300 \\
\hline PSMC6 & P62333 & 26S Protease regulatory subunit S10B & 44145 & 7.0 & 10 & 362 \\
\hline \multicolumn{7}{|c|}{ Mitochondrial Transmembrane Electron Transport System } \\
\hline $\mathrm{ACO} 2$ & Q99798 & Aconitate hydratase & 85372 & 7.3 & 8 & 177 \\
\hline АТР5B & P06576 & ATP synthase subunit beta & 56525 & 5.3 & 19 & 677 \\
\hline ATP5A1 & P25705 & ATP synthase subunit alpha & 59714 & 7.7 & 7 & 141 \\
\hline HSPA9B & P38646 & Stress-70 protein, mitochondria precursor & 73635 & 6.0 & 19 & 831 \\
\hline SOD2 & P04179 & Superoxide dismutase $(\mathrm{Mn})$ & 24707 & 6.9 & 1 & 34 \\
\hline UQCRC1 & P31930 & Ubiquinol-cytochrome-c reductase complex core protein I & 52612 & 5.6 & 6 & 135 \\
\hline HADHSC & Q16836 & Short chain 3-hydroxy-CoA dehydrogenase & 34256 & 8.3 & 4 & 121 \\
\hline PDHB & P11177 & Pyruvate dehydrogenase E1 component subunit beta & 39194 & 5.5 & 11 & 392 \\
\hline \multicolumn{7}{|l|}{ Glycolytic Cycle } \\
\hline${ }^{\$} \mathrm{ALDOA}$ & P04075 & Fructose-bisphosphate aldolase A & 39264 & 8.3 & 8 & 242 \\
\hline GAPDH & P04406 & Glyceraldehyde-3-phosphate dehydrogenase & 35899 & 8.5 & 24 & 536 \\
\hline LDH-A & P00338 & L-lactate dehydrogenase A chain & 36534 & 7.9 & 8 & 349 \\
\hline
\end{tabular}


Signal Transduction Related Proteins

\begin{tabular}{|c|c|c|c|c|c|c|}
\hline ARHGDIB & P52566 & Rho-GDP-dissociation inhibitor 2 & 22843 & 5.1 & 4 & 121 \\
\hline RANBP1 & P43487 & Ran-specific GTPase-activating protein & 23296 & 5.1 & 7 & 283 \\
\hline CALM2 & P62158 & Calmodulin & 16696 & 4.1 & 7 & 187 \\
\hline \multicolumn{7}{|l|}{ hers } \\
\hline AHSG & P02765 & Alpha-2-HS-glycoprotein precursor & 39300 & 5.2 & 4 & 149 \\
\hline FUBP1 & Q96AE4 & Far upstream element-binding protein 1 & 67431 & 7.1 & 9 & 268 \\
\hline
\end{tabular}

* Ions score is $-10 * \log (\mathrm{P})$, where $\mathrm{P}$ is the probability that the observed match is a random event. Individual ions scores $>27$ indicate identity or extensive homology $(\mathrm{P}<0.05)$.

$\S$ All proteins identified by Q-TOF MS

** Detailed peptides information are provided in Appendix

${ }^{\mathrm{s}}$ Not visualised in Cydyes labelled gel images 


\subsubsection{MTX down regulates proteasome subunits in HL-60 cells}

The proteasome, an ATP-dependent protease, modulates intracellular protein degradation (Voges et al., 1999). The multi-enzyme protease consists of a 20S core catalytic complex and two $19 \mathrm{~S}$ regulatory subunits. The $20 \mathrm{~S}$ core is a hollow, barrel shaped protein complex (Kisselev and Goldberg, 2001) composed of four stacked rings with an overall architecture of $\alpha(1-7) \beta(1-7) \beta(1-7) \alpha(1-7)$. The two outer $\alpha$ rings form-gated channel through which substrates enter and products exit the catalytic core. In addition, $\alpha$ subunits are also required for the recognition of ubiquitin tagged substrates and the unfolding of substrates prior to their threading into the proteolytic chamber (Glickman and Ciechanover, 2002). Interestingly, cysteine labelled differential in-gel electrophoresis analysis revealed that MTX significantly decreased the protein expression (\% spot volume data) of two structural proteasome subunits type $\alpha 4$, and $\alpha 7$ (PSMA4 and PSMA7), a non-catalytically proteasome subunit type $\beta 3$ (PSMB3) and two 26S protease regulatory subunits 8 (p45/SUG) and S10B (PSMC5 and PSMC6) from MTX treated HL-60 cells (Figure 13A\&B). One structural proteasome subunit type $\alpha 5$ (PSMA5) showed a statistical tendency of down regulation (\% spot volume data) in MTX treated HL-60 cells. In contrast, the \% spot volume data of $78 \mathrm{kDa}$ glucose regulated protein precursor (HSPA5) was found to be $0.46 \pm 0.02(\mathrm{p}<0.05)$ in MTX treated HL-60 cells as compared to untreated where the \% spot volume data was $0.375 \pm 0.005$ (Figure 12). Similarly, the \% spot volume data of calmodulin-2 (CALM2), a calcium binding protein was found to be $0.29 \pm 0.06(\mathrm{p}<0.09)$ in MTX treated HL-60 cells as compared to untreated where the \% spot volume data was $0.075 \pm 0.01$ (Figure 12). 


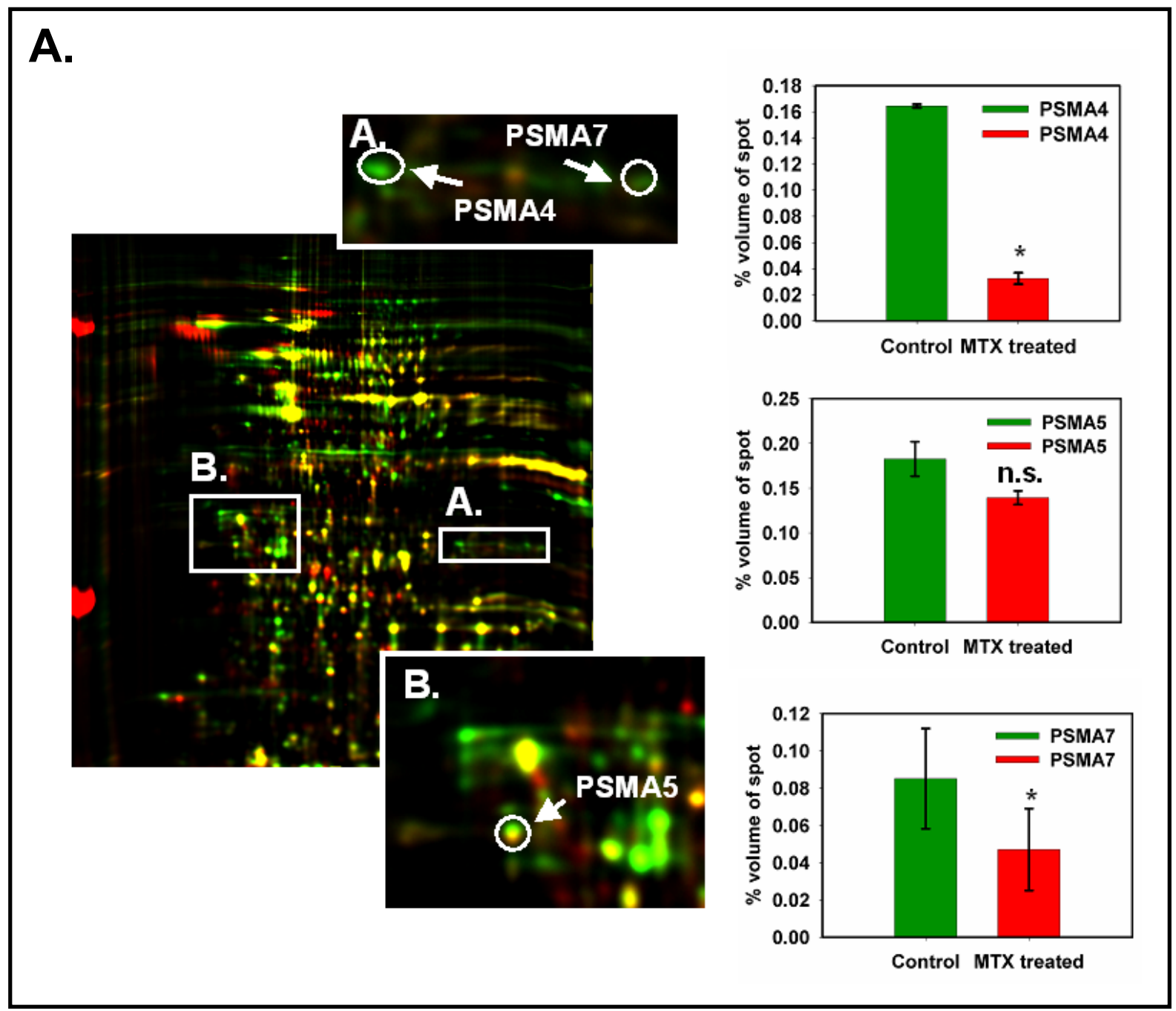




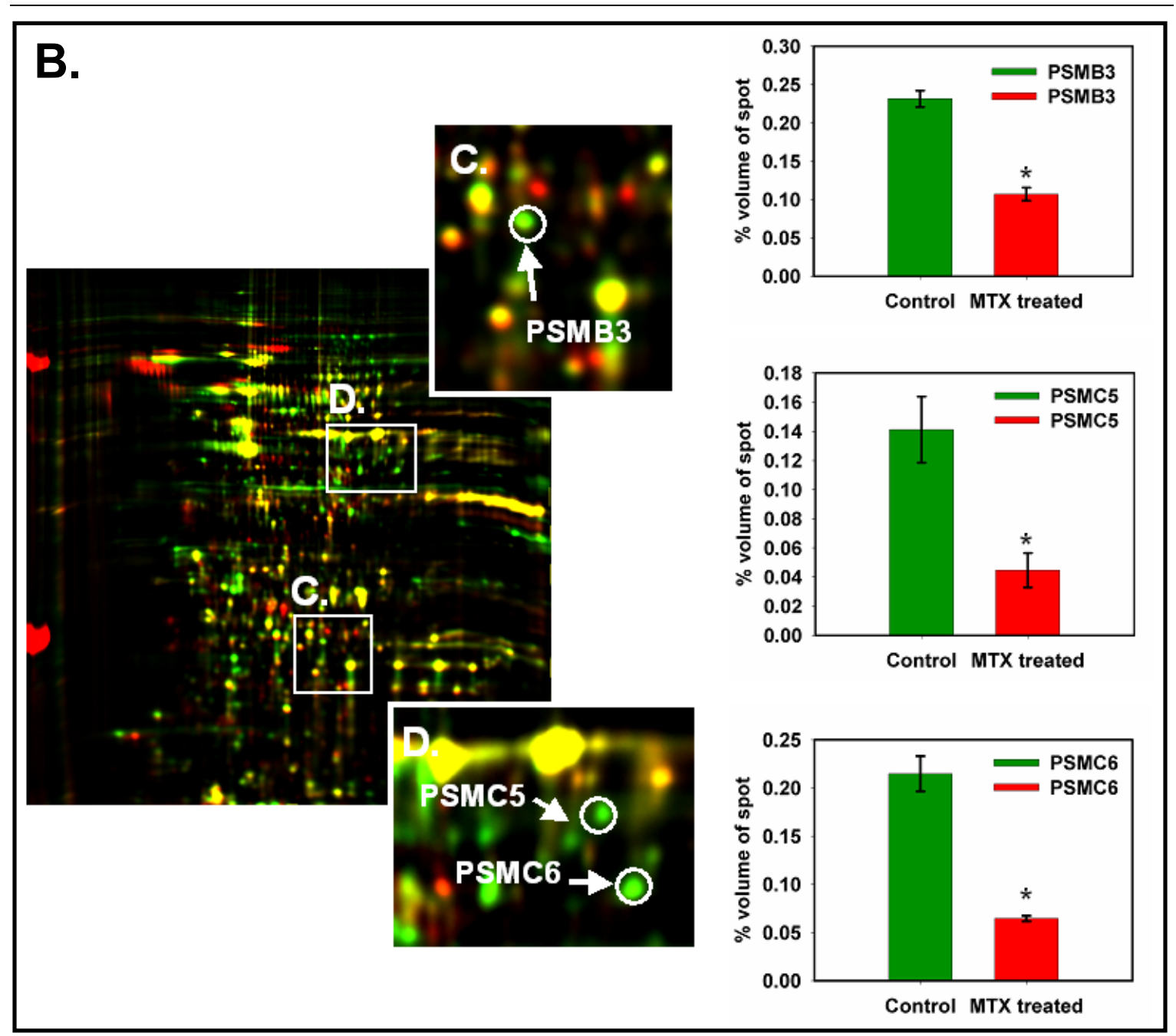

Figure 13. Down regulation of six proteasome subunits in MTX treated HL-60 cells

HL-60 cells were incubated without or with $2.5 \mu \mathrm{M}$ MTX in RPMI medium for 72 hours. Samples were then subjected to cysteine labelled differential in-gel electrophoresis using corresponding CyDyes for each sample. (A) Boxed areas in representative dual colour two-dimensional fluorescent image (A-B) have been enlarged and the corresponding close up mark areas (arrow and circle) of the gel image showing decrease expression of proteasome subunits (PSMA4, PSMA5 and PSMA7) in MTX treated HL-60 cell proteome. (B) Boxed areas in representative dual colour two-dimensional fluorescent image (C-D) have been enlarged and the corresponding close up mark areas (arrow and circle) of the gel image showing decrease expression of proteasome subunits (PSMB3, PSMC5 and PSMC6) in MTX treated HL-60 cell proteome. The protein expression quantification is presented as \% volume of spot (Y-axis) in front of enlarged boxed areas. Labelling of the spots correspond to the gene names as assigned in Table 4. Cy3 labelled proteins are shown in green colour (represent untreated HL-60 cell proteome) and Cy5 labelled proteins are in red colour (represent $2.5 \mu \mathrm{M}$ MTX treated HL-60 cell proteome). Results are given as the mean values \pm S.D. of $\%$ volume of spot from three independent experiments, $* \mathrm{p}<0.05$, n.s designates non-significant $\mathrm{p}$-value. 


\subsubsection{Differential effect of MTX on glycolytic and MTETS pathways}

Another important finding of this study revealed the impact of MTX on the carbohydrate metabolism in both type of cancer cells analysed by combined approaches. Cysteine labelled differential in-gel electrophoresis combined with mass spectrometry analyses showed that the protein expression (\% spot volume data) of several glycolytic enzymes such as glyceraldehydes-3-phosphate dehydrogenase (GAPDH), pyruvate kinase isoenzymes M1/M2 (PKM2) and L-lactate dehydrogenase A chain (LDH-A) were significantly increased in MTX treated HL-60 cells (Table 5). The inductions of the pyruvate kinase $(\mathrm{PKM} 2)$ activity $(\mathrm{p}<0.05)$ and triosephosphate isomerase $(\mathrm{TPI})$ were confirmed with enzyme activity assay and Western blotting, respectively (Figure 14A\&B). This reflected to a stimulation of the glycolytic pathway by MTX in both cancer cell lines. In contrast, the expression (\% spot volume data) level of pyruvate dehydrogenase E1 component subunit beta (PDHB) showed a statistical tendency of down regulation in MTX treated HL-60 cells (Table 5).

Table 5. Over expression of glycolytic enzymes in MTX treated HL-60 cells

\begin{tabular}{|c|c|c|c|c|}
\hline Name of the protein & Control & MTX treated & Detection Method & Figure Reference \\
\hline ALDOA & - & Up regulated & SS & Not shown \\
\hline TPI & $\S 1.00 \pm 00.00$ & $1.69 \pm 0.07$ & WB & Figure 15B \\
\hline GAPDH & $\$ 10.14 \pm 0.005$ & $13.91 \pm 0.33^{*}$ & CL-DIGE & Figure 12 \\
\hline PKM2 & ${ }^{\Delta} 0.99 \pm 0.09$ & $8.00 \pm 0.18^{*}$ & CL-DIGE \& EAA & Figure $12 \& 15 \mathrm{~A}$ \\
\hline LDH & ${ }^{\$} 0.08 \pm 0.01$ & $0.22 \pm 0.03^{*}$ & CL-DIGE & Figure 12 \\
\hline PHDB & $\$_{0.36 \pm 0.018}$ & $0.27 \pm 0.01$ & CL-DIGE & Figure 12 \\
\hline \multicolumn{5}{|c|}{ 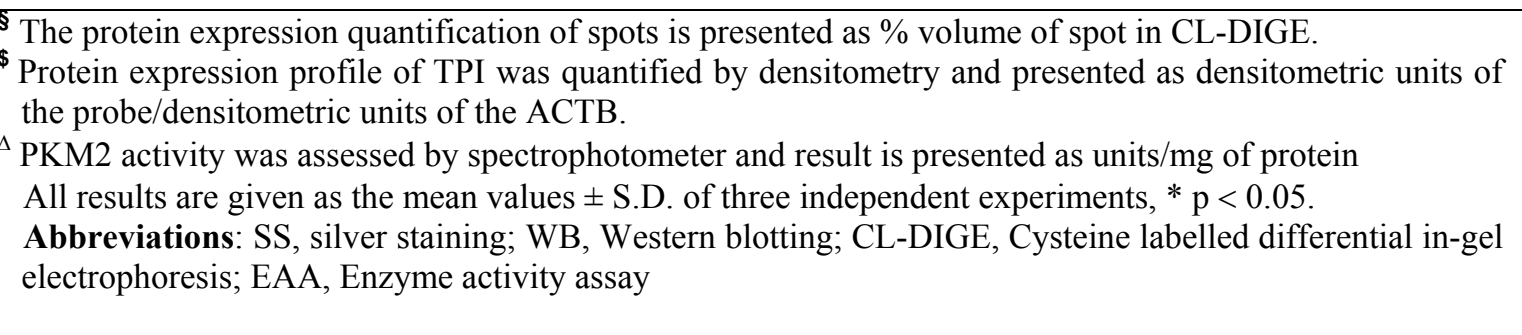 } \\
\hline
\end{tabular}




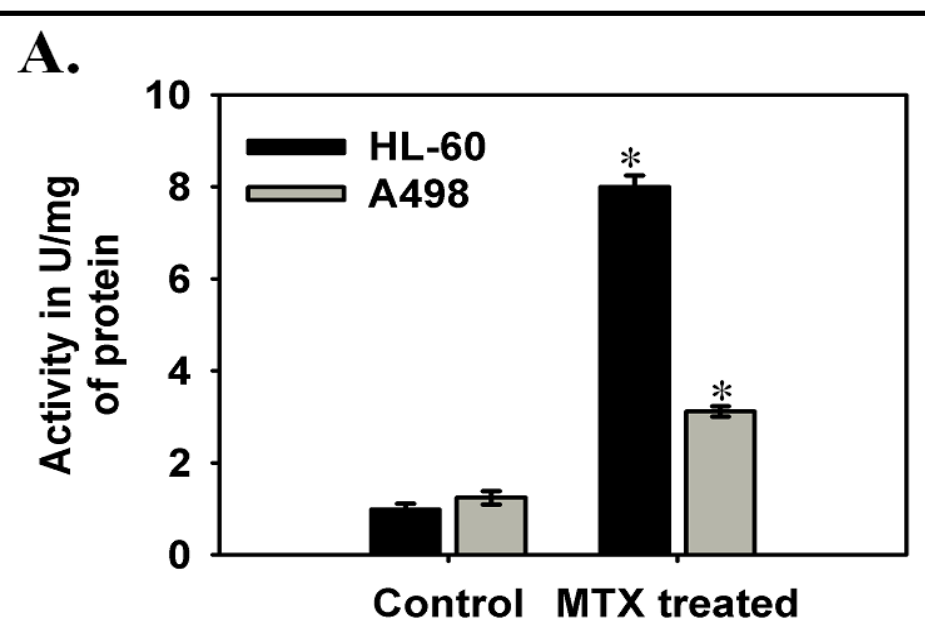

B.
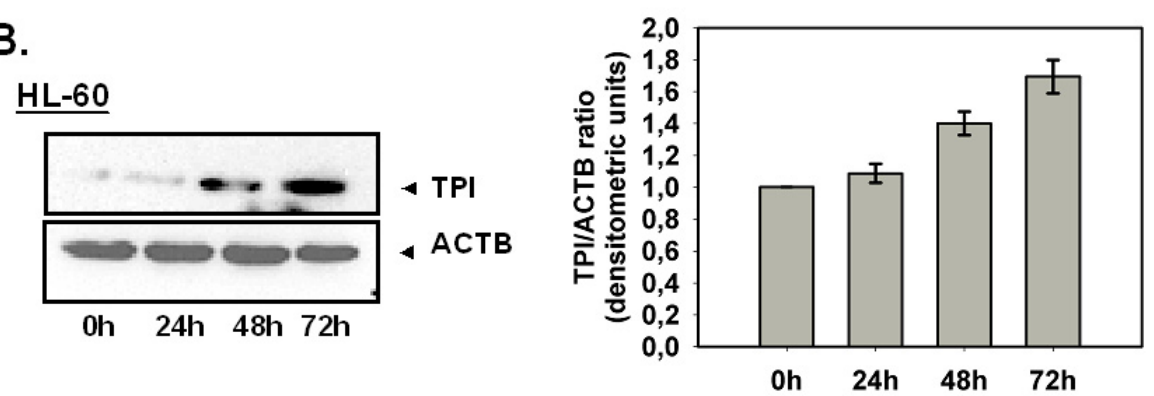

$\underline{\mathrm{A} 498}$
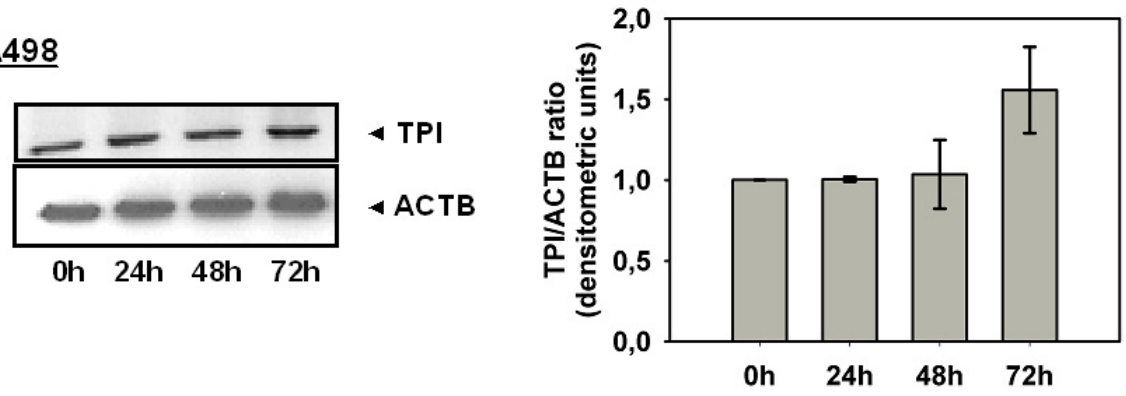

Figure 14. MTX induces pyruvate kinase activity and increases the expression of triosephosphate isomerase (TPI) in HL-60 and A498 cancer cells

HL-60 and A498 cells were incubated without or with $2.5 \mu \mathrm{M}$ and $45 \mu \mathrm{M}$ MTX respectively in corresponding mediums for 72 hours. Pyruvate kinase activity assay and western blotting were performed as described in the Experimental Procedures. (A) Effect of MTX on pyruvate kinase activity shown in above mentioned cancer cell lines. Pyruvate kinase activity was measured by spectrophotometer at the wavelength of $340 \mathrm{~nm}$ and presented as units/mg of protein in Y-axis. Results are given as the mean values \pm S.D. of three independent experiments, $* \mathrm{p}<0.05$. (B) Representative blots and bar diagrams depict the induction of TPI expression in MTX treated HL-60 and A498 cell lines in a time dependent manner whereas $\beta$-actin (ACTB) was used as an internal standard. Protein expression profile was quantified by densitometry and presented as densitometric units of the probe/densitometric units of the ACTB. The protein expression quantification was presented as grouped bar chart with error bars. Each bar represents the mean ratios \pm S.D. of protein intensity on the blots from three independent experiments. 
Similarly, seven mitochondrial-localized proteins were differentially expressed in MTX treated HL-60 cells that attributed to MTETS and beta-oxidation pathways. The protein expression (\% spot volume data) level of one mitochondrial precursor ATP synthase subunit beta (ATP5B; oxidative phosphorylation), (Figure 17A) two enzymes such as aconitate hydratase (ACO2; tricaboxylic acid cycle) and short chain 3-hydroxy-CoA dehydrogenase (HADHSC; beta-oxidation pathway) were significantly decreased in MTX treated HL-60 cells as compared to untreated. Similarly, the protein expression $(\%$ spot volume data) of superoxide dismutase Mn (SOD2) belonging to the intra-mitochondrial free radical scavenging enzyme was markedly down regulated $(p<0.05)$ in MTX treated HL-60 cells (Figure 15). In contrast, the expression (\% spot volume data) of threemitochondrial proteins such as mitochondrial precursor ATP synthase subunit alpha (ATP5A1) (Figure 17A), Ubiquinol cytocrome-c reductase complex core protein I (UQCRC1), and one stress-70 mitochondrial precursor (HSPA9B) were significantly increased in HL-60 cells after exposure to MTX for 72 hours (Figure 15). To elucidate whether MTX induced apoptotic protein profiles were cell specific, we performed the conventional proteomic analysis in A498 cells with and without MTX treatment for 72 hours. We found the similar results with majority of the proteins, yet subtle differences were detected. Moreover, the differences in protein expression profiles were found to be less intense in A498 as compared to MTX treated HL-60 cells (data not shown). 


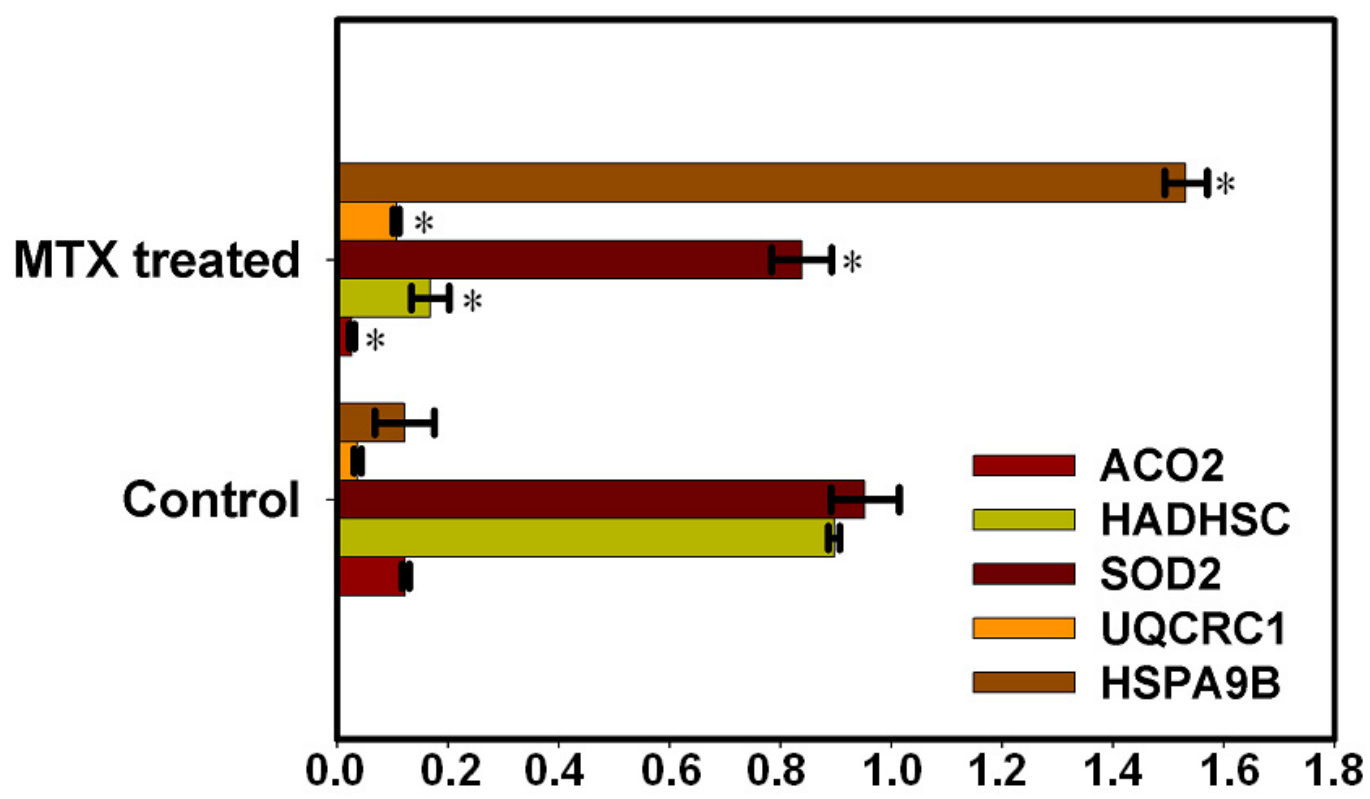

Figure 15. Differential expression of mitochondrial proteins in MTX treated HL-60 cell line

HL-60 cells were incubated without or with $2.5 \mu \mathrm{M}$ MTX in RPMI medium for 72 hours. Samples were subjected to cysteine labelled differential in-gel electrophoresis using specific CyDyes for each sample. Differentially expressed protein spots were quantified with Delta 2D software and plotted it on a bar diagram. The protein expression quantification data is presented as \% volume of spot (X-axis) and labelling of the spots corresponds to the gene names as assigned in Table 4. Results are given as the mean values \pm S.D. of $\%$ volume of spot from three independent experiments, $* p<0.05$.

\subsection{MTX INDUCES ER STRESS IS LINKED TO ALTERATION IN THE PROTEASOME PROTEIN EXPRESSION}

The proteasome is responsible for degradation of many intracellular proteins, thereby helping to maintain the cellular homeostasis during biological processes such as cell cycle, signal transduction, response to stress and gene transcription (Hershko and Ciechanover, 1998). Among other functions, the proteasomal complex rapidly degrades misfolded proteins to avoid accumulation of dysfunctional proteins (Kaufman, 2002; Ron, 2002). Moreover, proteasome inhibitors are known to act through the NF- $\kappa$ B pathway. 
This pathway is constitutively active in many types of cancer cells and is associated with cell proliferation, survival and protection from chemotherapy induced apoptosis (Wang et al., 1999). According to our Western blot and proteomic findings, MTX treated cancer cells showed decrease expression of the NF-кB subunit p65 (Figure 16B), which might be associated with an inhibition of proteasome subunits. This could lead to an increased accumulation of misfolded proteins in ER resulting in an ER stress response. To confirm the biological significance of our protein data, Western blot analyses were further performed to directly examine changes of the protein expression of ER chaperones. Interestingly, ER chaperones such as calreticulin precursor (CALR), protein disulphide isomerase $\mathrm{A} 3$ precursor (PDIA3), protein disulphide isomerase A4 precursor (PDIA4) and $78 \mathrm{kDa}$ glucose regulated protein precursor (HSPA5) were continuously up regulated in MTX treated HL-60 and A498 cells in a time dependent manner (Figure 16A).

\section{A. $\underline{\mathrm{HL}-60}$}

Oh 24h 48h $72 h$
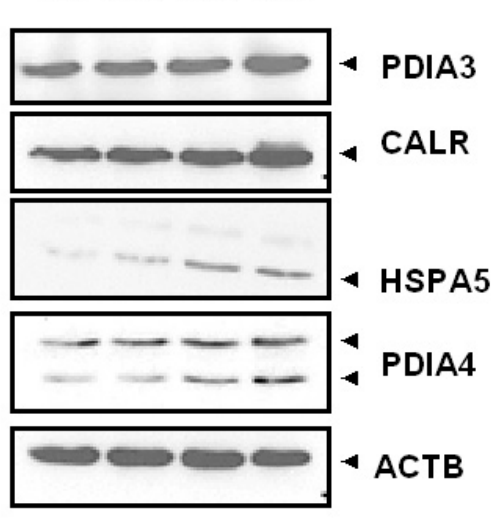
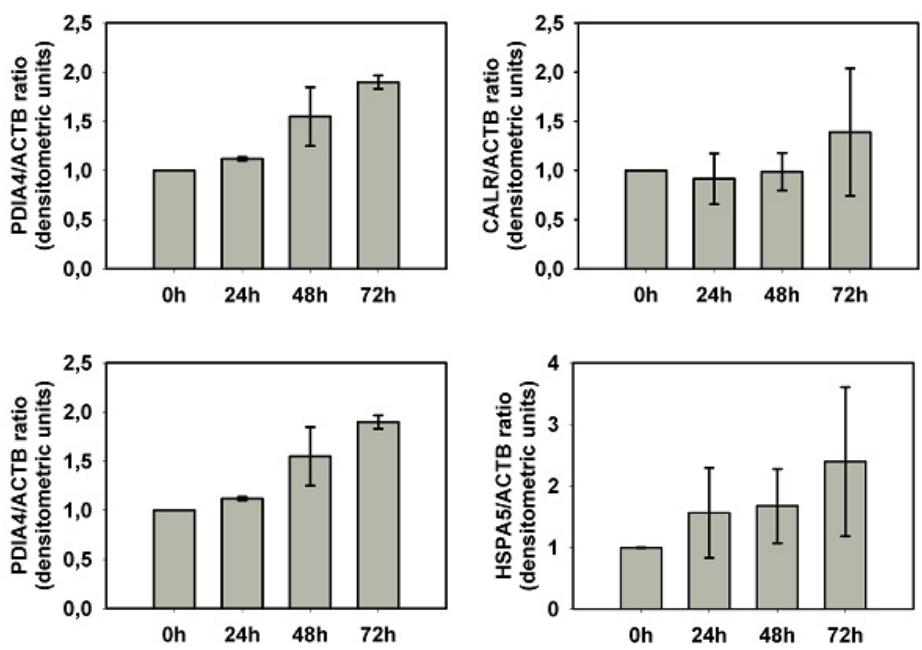

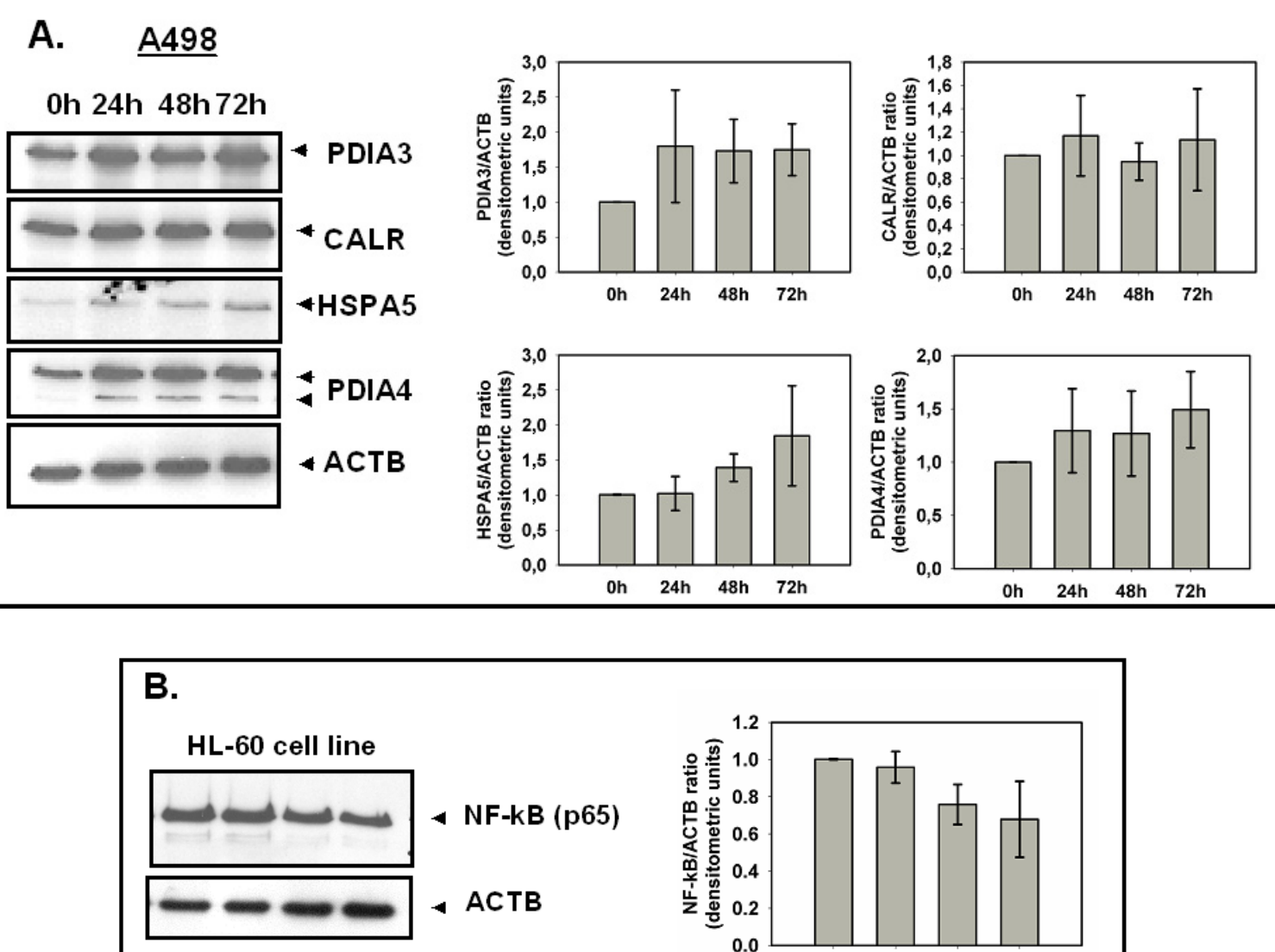

Oh $24 \mathrm{~h} \quad 48 \mathrm{~h} 72 \mathrm{~h}$
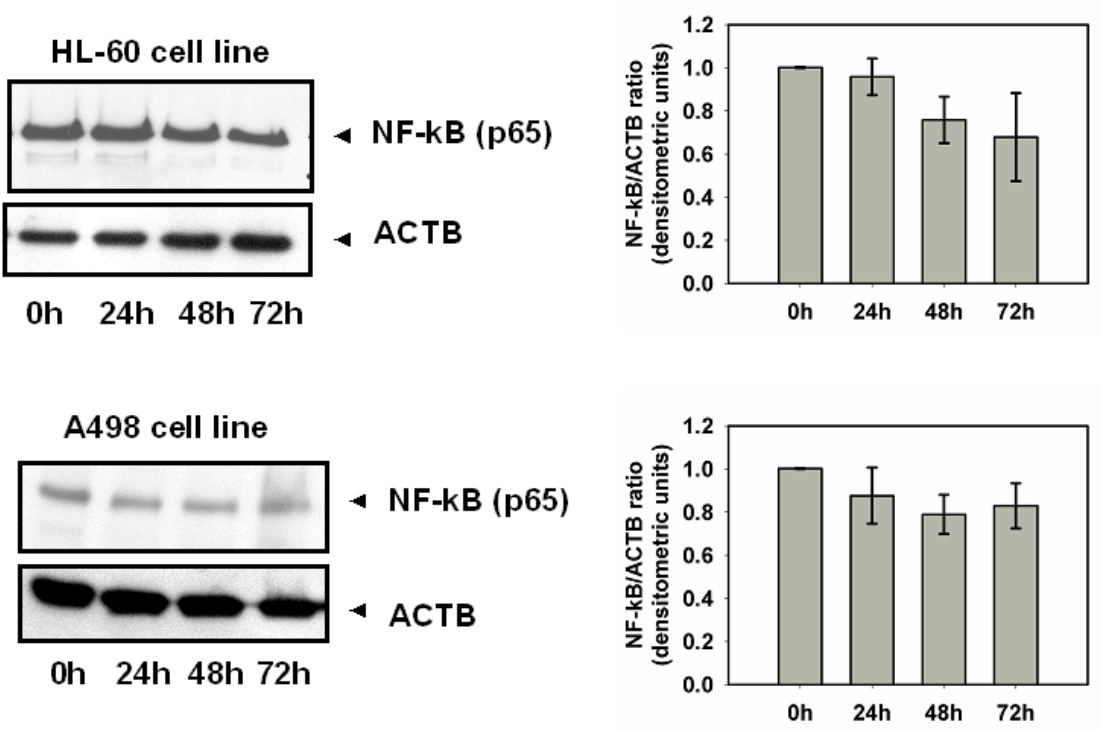

Figure 16. Western blot analyses of ER chaperones and NF- $\kappa B$ affected by MTX in HL-60 and A498 cancer cells

Representative bar diagrams and blots depict the changes of protein expression profile in MTX treated HL-60 and A498 cells, whereas $\beta$-actin (ACTB) was used as an internal standard. (A) Calreticulin precursor (CALR), protein disulphide isomerase A3 precursor (PDIA3), protein disulphide isomerase A4 precursor (PDIA4) and $78 \mathrm{kDa}$ glucose regulated protein precursor (HSPA5) (B) NF- $\kappa$ B. Protein expression profile was quantified by densitometry and presented as densitometric units of the probe/densitometric units of the ACTB. The expression quantification is presented as grouped bar chart with error bars. Each bar represents the mean ratios \pm S.D. of protein intensity on the blots from three independent experiments. 


\subsection{MTX ALTERS MITOCHONDRIAL MEMBRANE POTENTIAL AND} GENERATES ROS

The ATP synthase subunits catalyse ATP synthesis, utilizing an electrochemical gradient of protons across the inner membrane during oxidative phosphorylation and thus provide its function in energy transduction. In addition to these well established functions, multisubunits complex ATP synthase was recently shown to have a role in determining the ultrastructure of mitochondria (Arselin et al., 2003; Giraud et al., 2002; Paumard et al., 2002; Soubannier et al., 2002). Cysteine labelled differential in-gel electrophoresis analysis revealed that two proteins such as ATP synthase subunits alpha and beta (ATP5A1 and ATP5B) were differentially expressed in term of the $\%$ spot volume data in MTX treated HL-60 cells (Figure 17A). Furthermore, to determine the impact of ATP synthase subunits on MTX mediated apoptosis, the cationic cell-permeable JC-1 dye was utilized to calculate the electric potential of the membrane in both cell lines. We found that $\Delta \psi_{\mathrm{m}}$ was continuously dissipated in MTX treated HL-60 and A498 cells during the indicated time periods (Figure 17B). The differential proteins expression of ATP synthase subunits by MTX might causes structural alterations in the $\Delta \psi_{\mathrm{m}}$. These alterations in the ATP synthase subunits may play an important role in the collapse of $\Delta \psi_{\mathrm{m}}$ in MTX treated HL-60 and A498 cells. 

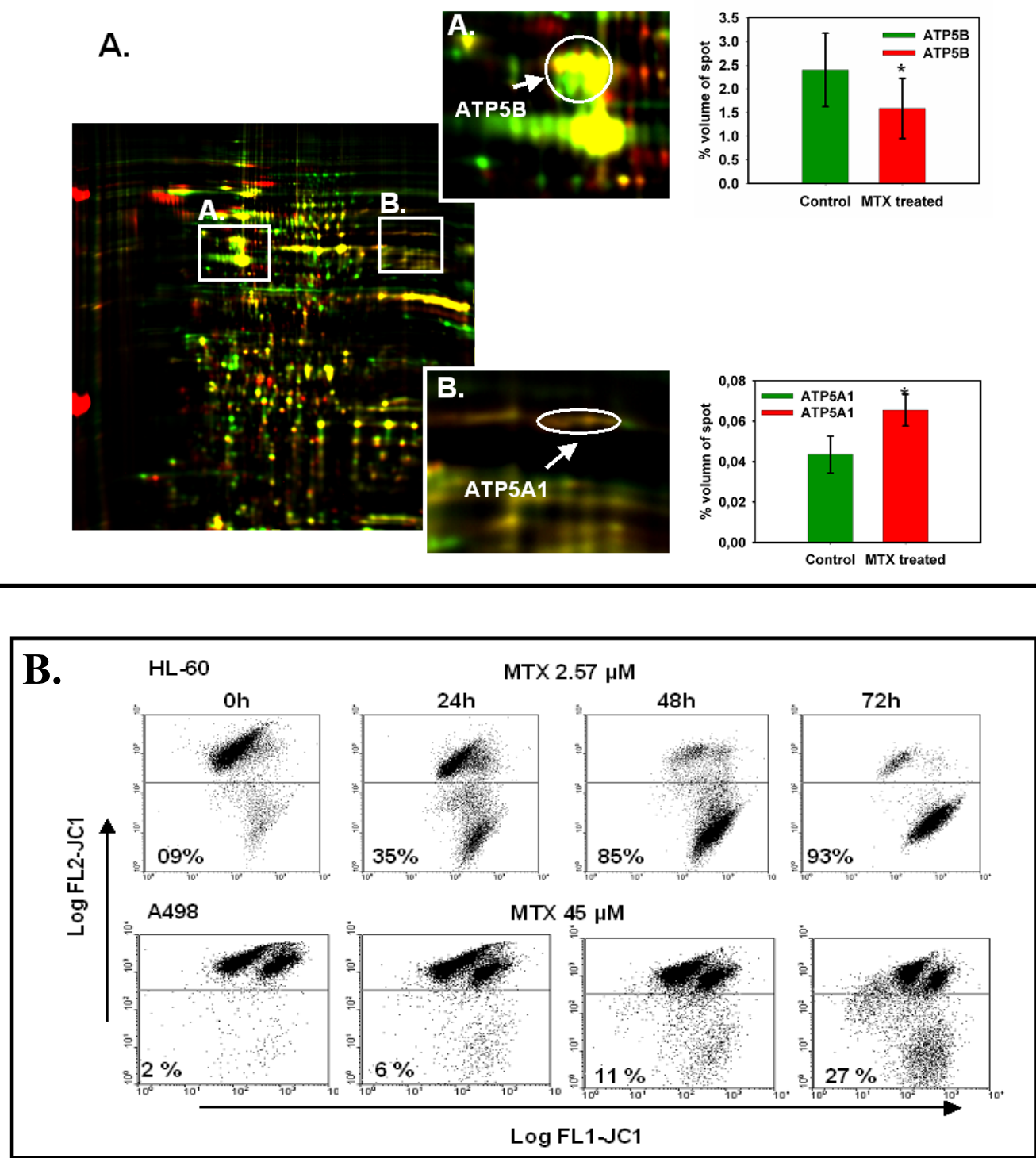

Figure 17. MTX induces apoptosis is associated with altered mitochondrial membrane potential

(A) HL-60 cells were incubated without or with $2.5 \mu \mathrm{M}$ MTX in RPMI medium for 72 hours. Cysteine labelled differential in-gel electrophoresis was performed using specific CyDyes for each sample. Boxed areas in representative dual colour two-dimensional fluorescent image (A\&B) have been enlarged and the corresponding close up mark areas (arrow and circle) of the gel showing differential expression of ATP synthase subunits alpha \& beta (ATP5A1 and ATP5B) in MTX treated HL-60 cell proteome. The protein expression quantification was presented as \% volume of spot (Y-axis) in front of enlarged boxed areas. Labelling of the spots correspond to the gene names as assigned in Table 4. Cy3 labelled proteins are shown in green colour (represent untreated HL-60 cell proteome) and Cy5 labelled proteins are in red colour (represent $2.5 \mu \mathrm{M}$ MTX treated HL-60 cell proteome). Results are given as the mean values \pm S.D. of $\%$ volume of spot from three independent experiments, $* \mathrm{p}<0.05$. (B) Influence of MTX on $\Delta \psi_{\mathrm{m}}$. Time-dependent loss of $\Delta \psi_{\mathrm{m}}$ was detected by flow cytometry in MTX treated HL-60 and A498 cells for the indicated time periods. 
Accumulating evidences suggest that alteration of ATP synthase biogenesis may cause two types of isolated defects: qualitative when the enzyme is structurally modified and does not function properly, and quantitative when it is present in insufficient amounts. In both cases the cellular energy formation is impaired and mitochondria promotes ROS generation by the mitochondrial respiratory chain (Houstek et al., 2006; Chen et al., 2003). Consistent with this notion we showed that SOD2 (useful marker of oxidative stress) is significantly down regulated in MTX treated HL-60 cells (Figure 15). To validate our previous finding, we analysed the production of the two most abundant ROS such as hydrogen peroxide $\left(\mathrm{H}_{2} \mathrm{O}_{2}\right)$ and peroxide nitrite anion (ONOO${ }^{-}$) using ROS-sensitive fluorescent dye DH-123 (Henderson and Chappell, 1993; Ichiki et al., 1994; Briviba et al., 1996) in A498 cells. We found that MTX treated A498 cells displayed a readily detectable increase in $\mathrm{H}_{2} \mathrm{O}_{2}$ and $\mathrm{ONOO}^{-}$levels compared to untreated cells in a time dependent manner (Figure 18A\& B). This induction in $\mathrm{H}_{2} \mathrm{O}_{2}$ and $\mathrm{ONOO}^{-}$ levels were generated in two distinct phases following MTX treatment. Initially, there was a small but consistent increase in $\mathrm{H}_{2} \mathrm{O}_{2}$ and $\mathrm{ONOO}^{-}$levels persisted for at least 72 hours (Figure 18A). This was further associated by substantial two-fold increase in $\mathrm{H}_{2} \mathrm{O}_{2}$ and $\mathrm{ONOO}^{-}$levels at 120 hours following MTX treatment in A498 cells (Figure 18A).

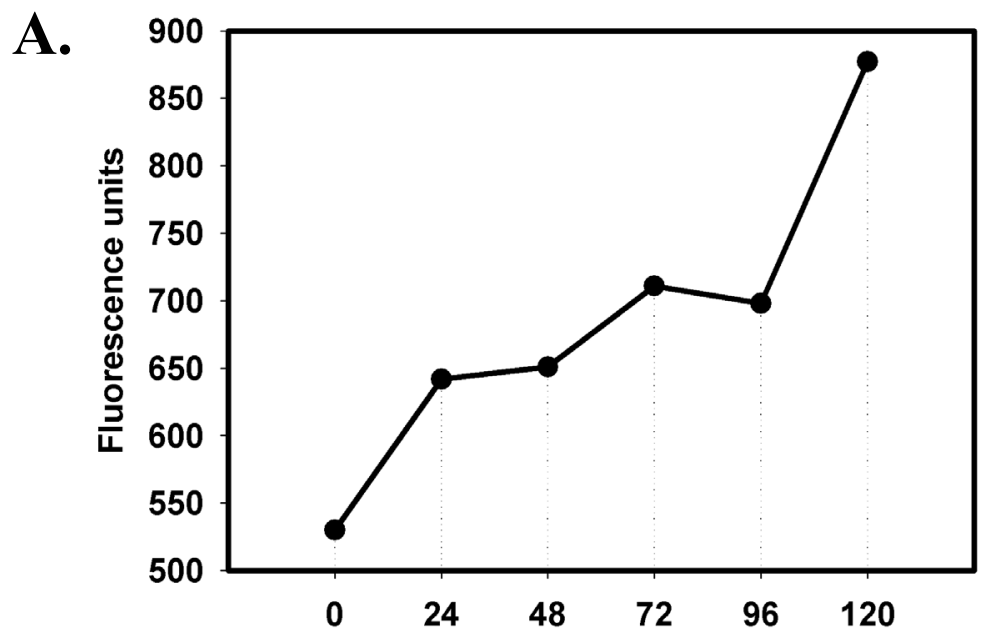




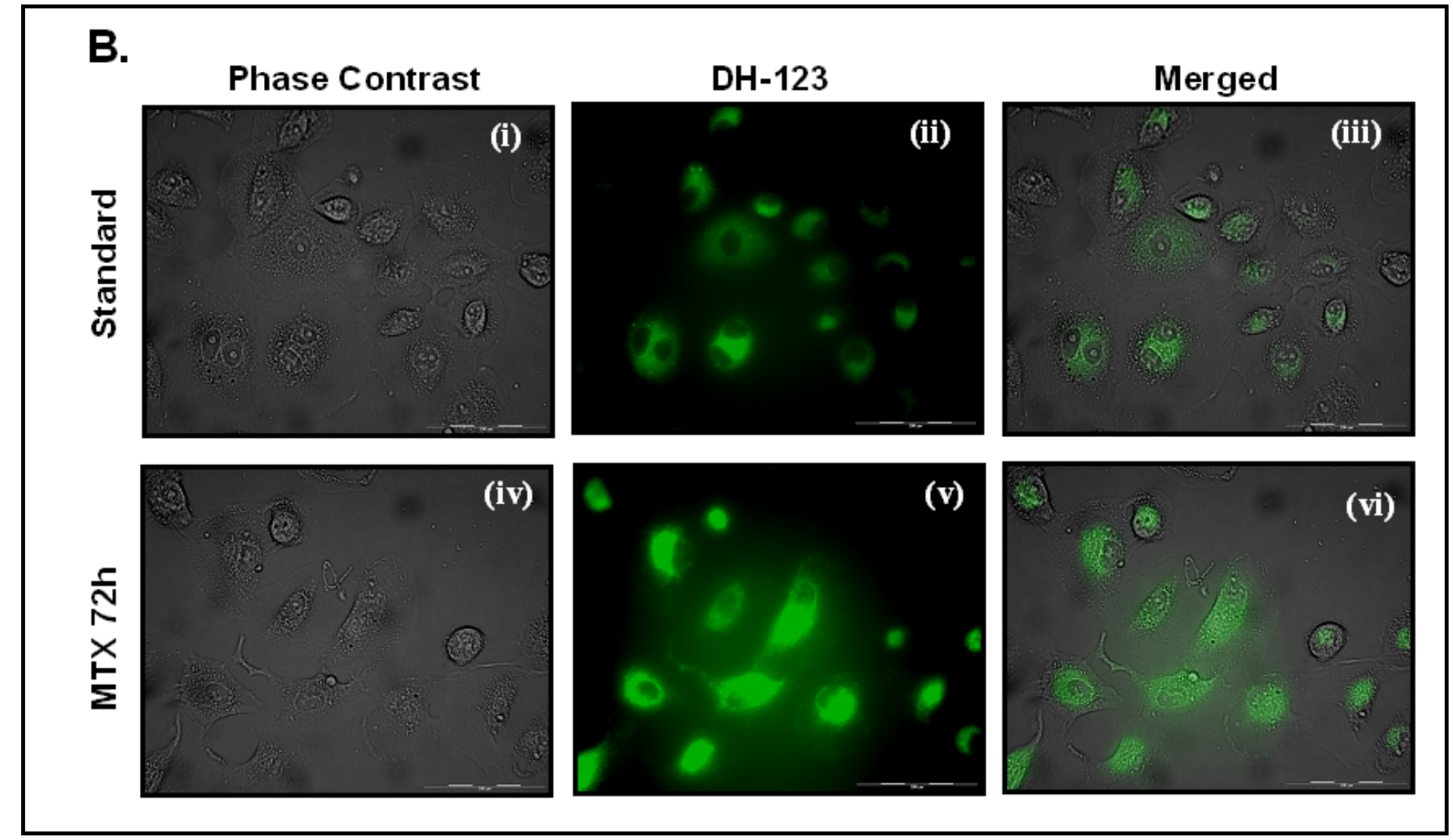

Figure 18. Induction of ROS formation in MTX treated A498 cells

(A) Representative graph shows the kinetics of oxidative stress in $45 \mu \mathrm{M}$ MTX untreated and treated A498 cells for the indicated time periods. Cells were stained with DH-123 for 2 hours, visualized by fluorescence microscopy using specific filter set for rhodamine. The fluorescence was calculated (in units) by randomly selected 100 cells. (B) Fluorescence microscopy comparing DH-123 stained untreated and treated A498 cells with $45 \mu \mathrm{M}$ MTX for 72 hours and visualized by using specific filter sets for phase contrast, rhodamine. The obtained figures were merged to observe cell morphology. These photographs were documented at an exposure of 40x magnification. 


\section{DISCUSSION}

Since 1948, Farber et al. showed that MTX could produce remission in acute leukaemia, the folate-dependent enzymes have been the curative regimen in acute lymphocytic leukaemia and other leukaemias (Farber, 1950). Various molecular targets have been proposed in MTX treated different cell types. However, the complete understanding of the molecular basis of drug action of MTX in cancer cells still remains unclear. In this study, we investigated a part of the cascade signalling involved in MTX induced apoptosis using novel proteomic approaches in acute promyelocytic leukaemia (HL-60) and renal epithelial carcinoma (A498) cells.

\subsection{SEQUENTIAL EVENTS OF APOPTOSIS INDUCED IN MTX TREATED CANCER CELLS}

Cancer chemotherapeutic drugs initiate cytotoxicity through pro-apoptotic signals incoming from various endogenous factors and converge upon pathways mediating programmed cell death or apoptosis. MTX, one of the earliest cancer chemotherapeutic agents showed cytotoxicity in acute lymphocytic leukemia (Farber, 1950) and other cancers (Frei, III et al., 1980). In our experimental model, we showed that MTX also causes cytotoxicity in acute promyelocytic cells (HL-60), which was mediated by induction of apoptosis. MTX exhibits apoptosis via changes in cellular morphology including cell shrinkage and induction in cellular granularity along with biochemical event leading to increase translocation of PtdSer at the surface of the plasma membrane (Figure 7A\&B; Figure 8A). It has been shown in numerous models that these morphological and biochemical alterations refers to an apoptosis (Kroemer et al., 2005; Martin et al., 1995). Irrespective to these morphological features, mitochondrial membrane permeabilization is an universal feature of cell death and is considered as a 
consequence of charge difference (mitochondrial membrane potential $\Delta \psi_{\mathrm{m}}$ ) between the mitochondrial matrix and cytosol (Kroemer et al., 1998). Our preliminary results revealed that MTX potentially disrupts $\Delta \psi_{\mathrm{m}}$ in HL-60 cells (Figure 17B). Structural irregularities due to the differential protein expression of ATP synthase subunits might be a critical factor participated in the $\Delta \psi_{\mathrm{m}}$ disruption in MTX treated HL-60 cells (Figure 17A). This $\Delta \psi_{\mathrm{m}}$ disruption constitutes an early event of apoptosis that precedes cell shrinkage, PtdSer translocation and induction of cellular granularity (Figure 17A). Similar findings have been obtained in freshly isolated splenocytes stimulated with dexamethasone (Zamzami et al., 1995). Following $\Delta \psi_{\mathrm{m}}$ dissipation and mitochondrial membrane permeabilization, an increase in mitochondrial matrix volume occurs as a consequence of the massive entry of solutes and water. This swelling give rise to a distention and disorganization of the mitochondrial membranes resulting in mitochondrial membranes fragmentation (Kroemer et al., 1998). In-vivo, such ultrastructural alterations have been previously observed in rat liver after exposure to MTX (Al Ali et al., 2005). Taking together, these data argue in favor of the possibility that besides morphological alterations, $\Delta \psi_{\mathrm{m}}$ disruption and partial lysis of the mitochondrial membranes participated in the apoptotic cascade induced by MTX.

To establish whether other cancer cells also showed MTX cytotoxicity, we investigated the effect of MTX on renal epithelial carcinoma (A498) cells. Similar findings i.e. induction of PtdSer translocation and $\Delta \psi_{\mathrm{m}}$ disruption were also observed in MTX treated renal epithelial carcinoma cells (A498) at a relatively lower rate than in HL-60 cells. This is probably due to the well-known differences in the expression of multi-drug resistance genes. Over expression of P-glycoprotein, multidrug resistance proteins and decreased expression of DNA topoisomerase-II are responsible for expression of the multidrug 
resistance phenotype in various cancer cells (Naito et al., 2000; Reinecke et al., 2000; Nishiyama et al., 1999).

\subsection{MOLECULAR TARGETS AND PATHWAYS INVOLVED IN CELL RESPONSE TO MTX}

Due to the wide therapeutic applications of MTX, it is reasonable to speculate that MTX may have a number of intracellular protein targets, converging into an apoptotic process. The inhibitory action of MTX on NADP-dependent enzymes has been extensively investigated by several authors (Babiak et al., 1998; Oliveira et al., 1989). Moreover, a number of important observations have been made which reflect towards the additional molecular influences of MTX such as inhibition of the ICMT (Winter-Vann et al., 2003) and suppression of the NF-kB subunits p65 and p50 (Majumdar and Aggarwal, 2001). Despite an increasing knowledge on the molecular targets of MTX in different cell types, little is known regarding its apoptotic influences in cancer cells.

Cysteine labelled differential in-gel electrophoresis combined with mass spectrometry has been successfully implemented in the proteomic study of adenoma of Min mice (Kondo et al., 2003), hepatocellular carcinoma tissue (Fujii et al., 2005), haematopoietic cells (Evans et al., 2004) and in the pathogenesis of the cancer (Kondo et al., 2003; Fujii et al., 2005). From a molecular targets point of view, there is currently substantial interest in implementing platforms for drug target discovery. Although the proteomic field is in the early stages, current proteomic tools such as cysteine labelled differential in-gel electrophoresis has the potential to be a major technique in identifying new molecular targets of various pharmacological therapeutic agents. In order to characterize the molecular targets of MTX induced apoptosis in HL-60 cells, we conducted experiments incorporating cysteine labelled differential in-gel electrophoresis. Initial experimental analysis revealed a number of differentially expressed proteins in acute promyelocytic 
leukemia HL-60 cells after exposure to MTX. These proteins were mainly ascribed to the ER chaperones, glycolytic enzymes and the mitochondrial transmembrane electron transport system (Table 4). Additionally, we observed that several proteasome subunits were significantly down regulated in MTX treated HL-60 cells (Figure 13A\&B). These results provide a broader view of intracellular protein changes accompanying the apoptotic effect of MTX in HL-60 cells.

\subsubsection{MTX induced inhibition of $N F-\kappa B$ subunit $p 65$ and proteasome subunits correlate with the induction of ER chaperones}

$\mathrm{NF}-\kappa \mathrm{B}$, a stress-regulated transcription factor belonging to the Rel family, has a pivotal role in the control of various responses. More than 200 physiological, pharmacological and chemotherapeutical stimuli are known to activate the NF- $\mathrm{BB}$ signalling pathway (Tergaonkar, 2006). The NF-кB activation pathways are broadly classified into two pathways commonly known as the canonical and non-canonical pathways, depending on whether activation involves the I $\mathrm{I} B$ degradation or p100 processing (Pomerantz and Baltimore, 2002). NF- $\mathrm{KB}$ activation and translocation into the nucleus induces the transcription of a variety of genes encoding cell adhesion molecules, inflammatory and chemotactic cytokines, cytokine receptors, and enzymes that produce inflammatory mediators. Accumulating evidences suggested that activation of NF- $\kappa \mathrm{B}$ is critical for the pathogenesis of leukaemia's (Baumgartner et al., 2002; Braun et al., 2006; Bueso-Ramos et al., 2004; Guzman et al., 2001). Hence, suppression of NF- $\mathrm{KB}$ and its associated signalling proteins could play an important role in cancer cell death. It has been shown that MTX down regulated NF- $\kappa$ B subunits p65 and p50 in Jurkat cells and was implicated in cell death (Majumdar and Aggarwal, 2001). Similiarily, MTX inhibits the expression of NF- $\kappa \mathrm{B}$ subunit p65 in acute promyelocytic leukaemia (HL-60) and renal epithelial carcinoma (A498) cells (Figure 16B). The results are in good agreement with what was 
previously reported for MTX treatment in Jurkat cells (Majumdar and Aggarwal, 2001). Majumdar and Aggarwal further demonstrated that the suppression of NF- $\mathrm{BB}$ subunits p65 and p50 was accompanied with the inhibition of IKB $\alpha$ degradation, suppression of $\mathrm{IKB} \alpha$ phosphorylation, abrogation of IKB $\alpha$ kinase activation, and inhibition of $\mathrm{NF}-\mathrm{KB}$ dependent reporter gene expression (Majumdar and Aggarwal, 2001). Recently, it has been shown that p65 subunit of NF- $\mathrm{kB}$ knockout (p65-/-) mouse embryonic fibroblasts (MEFs) cell line was found to be more susceptible to apoptosis with MTX as compared to wild type MEFs (Brengauz-Breitmann et al., 2006). Our findings combined with other studies (Brengauz-Breitmann et al., 2006; Majumdar and Aggarwal, 2001) indicate that MTX induced apoptosis in various cancer cell types is probably due to blocking NF- $\kappa \mathrm{B}$ activation. However, until recently how these pathways are integrated to each another is still to be determined.

In order to identify link between inhibition of NF-kB subunit p65 and apoptosis, we treated HL-60 cells with MTX and performed cysteine labelled differential in-gel electrophoresis combined with mass spectrometry. The important observations of this study were the down regulation of structurally $(\alpha 4, \alpha 5$ and $\alpha 7, \beta 3)$ and regulatory proteasome subunits in MTX treated HL-60 cells (Figure 13A\&B). Although the main catalytic activity of the proteasome is mediated by the $\beta$ subunits; the $\alpha$ and some regulatory subunits are thought to maintain the framework for correct assembly of $\beta$ subunits during biogenesis of the $20 \mathrm{~S}$ proteasome (Coux et al., 1996). Impairment of $\alpha$ and regulatory subunits thereby lead to instability in the $20 \mathrm{~S}$ proteasome complex resulting in impairment in proteasome mediated proteolytic activity (Bulteau et al., 2001; Grune et al., 1996; Voges et al., 1999). These evidences emphasize the possible involvement of MTX in the integrity of $\alpha$ and regulatory subunits to the normal function of proteasome in HL-60 cells. 
After observing the protein expression of proteasome subunits and its ability to induce apoptosis in MTX treated HL-60 cells, we therefore reasoned that lack of proteasomal activity might induces an abnormal accumulation of ubiquitinated proteins in ER finally causes ER stress. The resulting ER stress is characterized by over expression of ER chaperones, also known as unfolded protein response (Ron, 2002; Kaufman, 2002). The unfolded protein response includes three mechanisms to handle the vast accumulation of unfolded proteins: general transcriptional repression, translational induction of target proteins enhancing protein folding and ER-associated degradation pathway to eliminate misfolded proteins (Mori, 2000). If the overload of unfolded or misfolded proteins in the ER is not resolved, prolonged activation of the unfolded protein response would lead to apoptosis (Ron, 2002). In our study MTX activates unfolded protein response in HL-60 cells by inducing the expression of ER chaperones in a time dependent fashion (Figure 16A). Similar findings were also observed in MTX treated renal epithelial carcinoma cells (Figure 16A). The effects of MTX on ER chaperones are in accordance with earlier findings seen in various cancer cells after treated with proteasome inhibitors (Fribley and Wang, 2006; Obeng et al., 2006). These data confirmed the up regulation of ER chaperones in MTX treated HL-60 and A498 cells. How these proteins are integrated to each another by MTX is yet not clear.

\subsubsection{MTX induced MTETS proteins impairment reveal glycolysis involvement}

Most cancer cells exhibit increased glycolysis and use this metabolic pathway for the generation of the ATP as a main source of their energy supply in the absence of oxygen. This phenomenon is widely known as the Warburg effect and is considered as one of the fundamental metabolic alterations during malignant transformation (Garber, 2006; Wallace, 2005). Molecular studies imply several possible mechanisms by which this metabolic alteration may evolve during the cancer development. These mechanisms 
include adaptation to hypoxic tumour environment, oncogenic signalling, abnormal expression of the metabolic enzymes and mitochondrial defects or malfunction (Kim and Dang, 2005). As this metabolic alteration is frequently seen in cancer cells of various tissues, targeting the glycolytic pathway may cause apoptosis in malignant cancer cells. The effect of MTX on carbohydrate metabolism, in particular glycolytic enzymes have been investigated by several authors (Carpentier et al., 1978; Desoize et al., 1978; Kaminskas and Nussey, 1978). Some reports demonstrated that MTX enhances the intracellular levels of glycolytic enzymes in leukaemia L1210 cells (Desoize et al., 1978 and Carpentier Y and 1978). Conversely, there was a report suggesting that glycolysis was inhibited by MTX at growth inhibitory concentrations. The effect of MTX in cultured Ehrich ascites carcinoma cells was severe in low glucose containing media and intermediate in high glucose containing media (Kaminskas and Nussey, 1978), suggesting the importance of glucose in MTX pharmacological activity. Our proteomic data revealed that MTX significantly induces the expression of several glycolytic enzymes in HL-60 cells (Table 5; Figure 14A\&B). This is in concordance with earlier findings where MTX potentially enhances glycolysis in leukaemia L1210 cells (Desoize et al., 1978).

Earlier studies have shown that MTX can affect several aspects of mitochondrial energy metabolism, particularly oxidative phosphorylation and induces apoptosis in cancer cells (Oliveira et al., 1989; Gosalvez et al., 1974). The inhibitory effect of MTX on several mitochondrial enzymes such as 2-oxoglutarate and isocitrate dehydrogenase has been reported in the HeLa cells (Caetano et al., 1997). To explore the boarder view of mitochondrial-localized changes induced by MTX, we made cysteine labelled differential in-gel electrophoresis. We observed that MTX impaired seven additional mitochondriallocalized proteins (Figure 15) including ATP synthase subunits alpha and beta resulting in the $\Delta \psi_{\mathrm{m}}$ collapse as compared to control cancer cells (Figure 17A\&B). This study 
extends the list of mitochondrial-localized proteins affected by MTX in HL-60 cells. With the results shown herein, we may speculate that the biological significance resulting from the treatment with MTX leads to a reduction of the effectiveness of the MTETS followed by high glycolytic flux. The experimental data that indicate these are: Firstly increased expression of several enzymes such as ALDOA, GAPDH, PKM2 LDH-A and TPI, that will together contribute to increased glycolytic flux. Secondly differentially expression of mitochondrial proteins such as ATP5B, ACO2, ATP5A1, UQCRC1, SOD2 and HSPA9B besides 2-oxoglutarate, isocitrate and malate dehydrogenases (Caetano et al., 1997) were observed when the cancer cells were treated with MTX.

There are several reports demonstrating that apoptosis caused by MTX may be mediated by the production of ROS in Jurkat and HL-60 cells (Phillips et al., 2003; Huang et al., 2005). Conflicting evidences surround the effect of MTX on the generation of ROS in cell line models. One possible mechanism is that MTX decreases the cellular levels of glutathione and reduces the effectiveness of the antioxidant enzyme defence system (Babiak et al., 1998). In another study, MTX causes $\Delta \psi_{\mathrm{m}}$ disruption and causes apoptosis by increased the amount of cytosolic peroxide formation in HL-60 and Jurkat T cells (Huang et al., 2005). Our findings support latter study and showed that one of the mechanisms of MTX-induced apoptosis may be through a ROS-dependent, mitochondriamediated pathway. 


\section{CONCLUSION}

To conclude our findings, we demonstrate for the first time that structural noncatalytically and regulatory proteasom subunits were down regulated in MTX treated HL-60 cells. These evidences suggest the possible involvement of MTX in the integrity of $\alpha$ subunits to the normal function of proteasomes. Moreover, MTX down regulates NF- $\mathrm{BB}$ subunit p65 and induces the expression of the ER chaperones in HL-60 and A498 cells. Additionally, MTX leads to a reduction of the effectiveness of the MTETS followed by high glycolytic flux by altering mitochondrial-localized proteins and glycolytic enzymes. This leads to the generation of ROS in both cancer cell lines. 


\section{APPENDIX}

Protein Name:

Gene name:

Taxonomy:

Swiss Prot No:

Mass:

Score:

Queries matched:
Calreticulin precursor

\section{CALR}

Homo sapiens

P27797

48112

89

03

Summarized table of matched peptides:

$\begin{array}{llllllllll}\text { Query } & \text { Observed } & \text { Mr(expt) } & \text { Mr(calc) } & \text { Delta } & \text { Miss } & \text { Score } & \text { Expect Rank } & \text { Peptide } \\ 15 & 488.2570 & 974.4994 & 974.4781 & 0.0213 & 0 & 33 & 0.027 & 1 & \text { K.GLQTSQDAR.F } \\ 17 & 496.7465 & 991.4784 & 991.4611 & 0.0174 & 0 & 33 & 0.026 & 1 & \text { R.QIDNPDYK.G } \\ 22 & 565.7599 & 1129.5052 & 1129.4927 & 0.0125 & 1 & 23 & 0.16 & 1 & \text { K.FYGDEEKDK.G }\end{array}$




\section{Protein Name:}

Gene name:

Taxonomy:

Swiss Prot No:

Mass:

Score:

Queries matched:
Calmodulin

CALM2

Homo sapiens

P62158

16696

187

07

Summarized table of matched peptides:

$\begin{array}{llll}\text { Query } & \text { Observed } & \text { Mr (expt) } & \text { Mr (calc) } \\ 4 & 411.2409 & 820.4672 & 820.4113 \\ 16 & 478.7747 & 955.5348 & 955.4651 \\ 21 & 547.2792 & 1092.5438 & 1092.4571 \\ 23 & 633.3598 & 1264.7050 & 1264.6047 \\ 27 & 456.9017 & 1367.6833 & 1367.5874 \\ 34 & 585.6729 & 1753.9969 & 1753.8634 \\ 35 & 923.0095 & 1844.0044 & 1843.8839\end{array}$

\section{Delta Miss Score Expect Rank Peptide}

$\begin{array}{llllll}0.0560 & 0 & 4 & 13 & 1 & \text { K.ELGTVMR.S + Oxidation (M) } \\ 0.0698 & 0 & 47 & 0.0007 & 1 & \text { K.EAFSLFDK.D } \\ 0.0868 & 0 & 42 & 0.0023 & 1 & \text { K.DTDSEEEIR.E } \\ 0.1003 & 0 & 43 & 0.0016 & 1 & \text { K.DGNGYISAAELR.H } \\ 0.0958 & 1 & 34 & 0.017 & 1 & \text { K.MKDTDSEEEIR.E + Oxidation (M) } \\ 0.1334 & 1 & 11 & 1.9 & 1 & \text { R.VFDKDGNGYISAAELR.H } \\ 0.1205 & 1 & 6 & 8 & 1 & \text { K.EAFSLFDKDGDGTITTK.E }\end{array}$


Protein Name:

Gene name:

Taxonomy:

Swiss Prot No:

Mass:

Score:

Queries matched:
$78 \mathrm{kDa}$ Glucose regulated protein precursor (Bip protein)

\section{HSPA5}

Homo sapiens

P11021

72288

989

23

Summarized table of matched peptides:

$\begin{array}{llll}\text { Query } & \text { Observed } & \text { Mr(expt) } & \text { Mr(calc) } \\ 17 & 459.7444 & 917.4742 & 917.4706 \\ 18 & 491.2532 & 980.4918 & 980.4814 \\ 19 & 493.7692 & 985.5238 & 985.5080 \\ 24 & 523.7980 & 1045.5814 & 1045.5655 \\ 27 & 537.7851 & 1073.5556 & 1073.5465 \\ 33 & 596.3239 & 1190.6332 & 1190.6295 \\ 34 & 609.3318 & 1216.6490 & 1216.6234 \\ 35 & 614.8340 & 1227.6534 & 1227.6207 \\ 36 & 617.3259 & 1232.6372 & 1232.6183 \\ 45 & 658.8332 & 1315.6518 & 1315.6295 \\ 51 & 699.4104 & 1396.8062 & 1396.7813 \\ 52 & 715.8542 & 1429.6938 & 1429.6837 \\ 56 & 730.8893 & 1459.7640 & 1459.7518 \\ 61 & 768.9067 & 1535.7988 & 1535.7905 \\ 62 & 776.9102 & 1551.8058 & 1551.7854 \\ 63 & 783.8982 & 1565.7818 & 1565.7725 \\ 64 & 794.8961 & 1587.7776 & 1587.8467 \\ 65 & 530.2718 & 1587.7936 & 1587.8467 \\ 70 & 830.4575 & 1658.9004 & 1658.8879 \\ 71 & 839.4112 & 1676.8078 & 1676.8005 \\ 79 & 918.9685 & 1835.9224 & 1835.9265 \\ 82 & 629.9977 & 1886.9713 & 1886.9638 \\ 84 & 1088.4921 & 2174.9696 & 2174.9855\end{array}$

$\begin{array}{llllll}\text { Delta } & \text { Miss } & \text { Score } & \text { Expect Rank } & \text { Peptide } \\ 0.0037 & 0 & 33 & 0.022 & 1 & \text { K.VLEDSDLK.K } \\ 0.0104 & 0 & 10 & 3.8 & 1 & \text { K.ETAEAYLGK.K } \\ 0.0159 & 0 & 27 & 0.08 & 1 & \text { R.LTPEEIER.M } \\ 0.0159 & 1 & 47 & 0.00099 & 1 & \text { K.VLEDSDLKK.S } \\ 0.0091 & 0 & 45 & 0.0013 & 1 & \text { K.ITITNDQNR.L } \\ 0.0038 & 0 & 52 & 0.00028 & 1 & \text { K.VYEGERPLTK.D } \\ 0.0257 & 0 & 32 & 0.024 & 1 & \text { K.DAGTIAGLNVMR.I } \\ 0.0327 & 0 & 48 & 0.00065 & 1 & \text { R.VEIIANDQGNR.I } \\ 0.0190 & 0 & 41 & 0.0031 & 1 & \text { K.DAGTIAGLNVMR.I + Oxidation }(\mathrm{M}) \\ 0.0223 & 0 & 76 & 1.1 \mathrm{e}-06 & 1 & \text { R.NELESYAYSLK.N } \\ 0.0250 & 0 & 62 & 1.6 \mathrm{e}-051 & \text { K.ELEEIVQPIISK.L } \\ 0.0101 & 0 & 48 & 0.00064 & 1 & \text { R.TWNDPSVQQDIK.F } \\ 0.0123 & 0 & 47 & 0.0008 & 1 & \text { K.SDIDEIVLVGGSTR.I } \\ 0.0084 & 0 & 49 & 0.000461 & \text { K.TFAPEEISAMVLTK.M } \\ 0.0204 & 0 & 44 & 0.0012 & 1 & \text { K.TFAPEEISAMVLTK.M + Oxidation }(\mathrm{M}) \\ 0.0093 & 0 & 50 & 0.00036 & 1 & \text { R.ITPSYVAFTPEGER.L } \\ -0.0691 & 1 & 4 & 15 & 1 & \text { K.KSDIDEIVLVGGSTR.I } \\ -0.0532 & 1 & 20 & 0.36 & 1 & \text { K.KSDIDEIVLVGGSTR.I } \\ 0.0126 & 0 & 93 & 1.5 \mathrm{e}-08 & 1 & \text { R.IINEPTAAAIAYGLDK.R } \\ 0.0073 & 0 & 92 & 2.2 \mathrm{e}-08 & 1 & \text { K.NQLTSNPENTVFDAK.R } \\ -0.0040 & 0 & 103 & 1.9 \mathrm{e}-09 & 1 & \text { K.SQIFSTASDNQPTVTIK.V } \\ 0.0074 & 0 & 26 & 0.074 & 1 & \text { K.VTHAVVTVPAYFNDAQR.Q } \\ -0.0158 & 1 & 23 & 0.14 & 1 & \text { K.LYGSAGPPPTGEEDTAEKDEL }\end{array}$


Protein Name:

Gene name:

Taxonomy:

Swiss Prot No:

Mass:

Score:

Queries matched:
Proteasome subunit alpha type 4

$$
\text { PSMA4 }
$$

Homo sapiens

P25789

29465

236

09

Summarized table of matched peptides:

$\begin{array}{llll}\text { Query } & \text { Observed } & \text { Mr(expt) } & \text { Mr(calc) } \\ 15 & 429.7823 & 857.5500 & 857.4858 \\ 24 & 451.7991 & 901.5836 & 901.5233 \\ 29 & 500.2776 & 998.5406 & 998.4821 \\ 30 & 504.3059 & 1006.5972 & 1006.5083 \\ 31 & 504.3088 & 1006.6030 & 1006.5083 \\ 41 & 557.8675 & 1113.7204 & 1113.6393 \\ 46 & 613.8656 & 1225.7166 & 1225.6230 \\ 56 & 477.6494 & 1429.9264 & 1429.8140 \\ 61 & 804.4542 & 1606.8938 & 1606.7807\end{array}$

$\begin{array}{llllll}\text { Delta } & \text { Miss } & \text { Score } & \text { Expect Rank } & \text { Peptide } \\ 0.0643 & 0 & 6 & 7.9 & 5 & \text { K.EVEQLIK.K } \\ 0.0604 & 0 & 37 & 0.0036 & 1 & \text { K.VEIATLTR.E } \\ 0.0585 & 0 & 40 & 0.0036 & 1 & \text { K.QAYTQFGGK.R } \\ 0.0889 & 0 & 10 & 2.9 & 1 & \text { R.TTIFSPEGR.L } \\ 0.0947 & 0 & 30 & 0.026 & 1 & \text { R.TTIFSPEGR.L } \\ 0.0811 & 1 & 3 & 7.2 & 1 & \text { K.QKEVEQLIK.K } \\ 0.0936 & 0 & 66 & 7 \mathrm{e}-06 & 1 & \text { K.LLDEVFFSEK.I } \\ 0.1124 & 1 & 3 & 2.7 & 1 & \text { K.LSAEKVEIATLTR.E } \\ 0.1132 & 0 & 53 & 0.00015 & 1 & \text { K.ATCIGNNSAAAVSMLK.Q + Carbamidomethyl (C) }\end{array}$




\section{Protein Name:}

Gene name:

Taxonomy:

Swiss Prot No:

Mass:

Score:

Queries matched:
Proteasome subunit alpha type 5

PSMA5

Homo sapiens

P28066

26394

274

08

Summarized table of matched peptides:

$\begin{array}{llll}\text { Query } & \text { Observed } & \text { Mr(expt) } & \text { Mr(calc) } \\ 14 & 494.7848 & 987.5550 & 987.5124 \\ 17 & 532.2729 & 1062.5312 & 1062.5094 \\ 22 & 608.8397 & 1215.6648 & 1215.6234 \\ 28 & 712.4234 & 1422.8322 & 1422.7758 \\ 29 & 716.3946 & 1430.7746 & 1430.7327 \\ 30 & 724.3927 & 1446.7708 & 1446.7276 \\ 31 & 981.5009 & 1960.9872 & 1960.9490 \\ 32 & 654.6804 & 1961.0194 & 1960.9490\end{array}$

$\begin{array}{llllll}\text { Delta } & \text { Miss } & \text { Score } & \text { Expect Rank } & \text { Peptide } \\ 0.0427 & 0 & 40 & 0.0039 & 1 & \text { K.EELEEVIK.D } \\ 0.0219 & 0 & 25 & 0.16 & 1 & \text { R.GVNTFSPEGR.L } \\ 0.0415 & 1 & 25 & 0.12 & 1 & \text { K.EELEEVIKDI } \\ 0.0564 & 0 & 65 & 7.9 \mathrm{e}-06 & 1 & \text { R.LFQVEYAIEAIK.L } \\ 0.0420 & 0 & 37 & 0.0067 & 1 & \text { R.ITSPLMEPSSIEK.I } \\ 0.0433 & 0 & 30 & 0.034 & 1 & \text { R.ITSPLMEPSSIEK.I + Oxidation (M) } \\ 0.0383 & 0 & 82 & 1.9 \mathrm{e}-07 & 1 & \text { R.AIGSASEGAQSSLQEVYHK.S } \\ 0.0704 & 0 & 5 & 9.1 & 1 & \text { R.AIGSASEGAQSSLQEVYHK.S }\end{array}$




\section{Protein Name:}

Gene name:

Taxonomy:

Swiss Prot No:

Mass:

Score:

Queries matched:
Proteasome subunit alpha type 7

$$
\text { PSMA7 }
$$

Homo sapiens

o14818

27870

255

06

Summarized table of matched peptides:

$\begin{array}{llll}\text { Query } & \text { Observed } & \text { Mr(expt) } & \text { Mr(calc) } \\ 6 & 426.2604 & 850.5062 & 850.4436 \\ 16 & 486.3261 & 970.6376 & 970.5698 \\ 21 & 542.8480 & 1083.6814 & 1083.5811 \\ 22 & 550.8622 & 1099.7098 & 1099.6237 \\ 27 & 817.9969 & 1633.9792 & 1633.8563 \\ 30 & 870.9689 & 1739.9232 & 1739.8101\end{array}$

$\begin{array}{llllll}\text { Delta } & \text { Miss } & \text { Score } & \text { Expect Rank } & \text { Peptide } \\ 0.0627 & 0 & 17 & 0.46 \quad 1 & \text { K.YVAEIEK.E } \\ 0.0678 & 0 & 43 & 0.000841 & \text { R.DIVVLGVEK.K } \\ 0.1003 & 0 & 42 & 0.0011 \quad 1 & \text { K.ILNPEEIEK.Y } \\ 0.0862 & 0 & 46 & 0.000391 & \text { K.ALLEVVQSGGK.N } \\ 0.1230 & 0 & 46 & 0.00043 & 1 & \text { R.LTVEDPVTVEYITR.Y } \\ 0.1131 & 0 & 63 & 1.7 \mathrm{e}-051 & \text { K.NYTDEAIETDDLTIK.L }\end{array}$




\section{Protein Name:}

Gene name:

Taxonomy:

Swiss Prot No:

Mass:

Score:

Queries matched:
Proteasome subunit beta type 3

\section{PSMB3}

Homo sapiens

$\mathrm{P} 49720$

22933

215

07

Summarized table of matched peptides:

$\begin{array}{llll}\text { Query } & \text { Observed } & \text { Mr(expt) } & \text { Mr(calc) } \\ 14 & 446.7784 & 891.5422 & 891.5065 \\ 19 & 495.2643 & 988.5140 & 988.4760 \\ 25 & 784.4592 & 1566.9038 & 1566.8439 \\ 26 & 815.4222 & 1628.8298 & 1628.7868 \\ 27 & 883.9803 & 1765.9460 & 1765.8926 \\ 30 & 630.3754 & 1888.1044 & 1888.0417 \\ 31 & 945.0665 & 1888.1184 & 1888.0417\end{array}$

\begin{tabular}{llllll} 
Delta & Miss & Score & \multicolumn{2}{l}{ Expect Rank } & Peptide \\
& & & & & \\
0.0357 & 0 & 10 & 2.5 & 1 & R.LNLYELK.E \\
0.0381 & 0 & 32 & 0.03 & 1 & K.NCVAIAADR.R + Carbamidomethyl (C) \\
0.0600 & 0 & 42 & 0.0016 & 1 & R.DAVSGMGVIVHIIEK.D \\
0.0430 & 0 & 23 & 0.18 & 1 & R.FGIQAQMVTTDFQK.I + Oxidation (M) \\
0.0534 & 0 & 50 & 0.00032 & 1 & R.FGPYYTEPVIAGLDPK.T \\
0.0626 & 0 & 15 & 0.55 & 1 & R.LYIGLAGLATDVQTVAQR.L \\
0.0767 & 0 & 58 & $2.3 \mathrm{e}-05$ & 1 & R.LYIGLAGLATDVQTVAQR.L
\end{tabular}


Protein Name:

Gene name:

Taxonomy:

Swiss Prot No:

Mass:

Score:

Queries matched:
26S Protease regulatory subunit 8 (p45/SUG)

\section{PSMC5}

Homo sapiens

P62195

45597

300

09

Summarized table of matched peptides:

$\begin{array}{llll}\text { Query } & \text { Observed } & \text { Mr (expt) } & \text { Mr (calc) } \\ 3 & 401.2498 & 800.4850 & 800.4068 \\ 15 & 463.8220 & 925.6294 & 925.5484 \\ 17 & 473.8017 & 945.5888 & 945.5131 \\ 20 & 489.2747 & 976.5348 & 976.4614 \\ 26 & 579.8720 & 1157.7294 & 1157.6444 \\ 28 & 645.8521 & 1289.6896 & 1289.5847 \\ 29 & 649.8703 & 1297.7260 & 1297.6302 \\ 30 & 657.4189 & 1312.8232 & 1312.7238 \\ 34 & 715.8962 & 1429.7778 & 1429.6620\end{array}$

$\begin{array}{llllll}\text { Delta } & \text { Miss } & \text { Score } & \text { Expect Rank } & \text { Peptide } \\ 0.0782 & 0 & 4 & 17 & 1 & \text { R.QYYLSK.I } \\ 0.0811 & 0 & 20 & 0.056 & 1 & \text { K.EVIELPVK.H } \\ 0.0758 & 0 & 47 & 0.00045 & 1 & \text { R.VSGSELVQK.F } \\ 0.0735 & 0 & 7 & 10 & 1 & \text { R.NDSYTLHK.I } \\ 0.0851 & 0 & 30 & 0.02 & 1 & \text { K.GVLLYGPPGTGK.T } \\ 0.1049 & 0 & 67 & 7.4 \mathrm{e}-06 & 1 & \text { R.LEGGSGGDSEVQR.T } \\ 0.0958 & 0 & 14 & 1.1 & 1 & \text { K.IEFPPPNEEAR.L } \\ 0.0995 & 0 & 59 & 1.8 \mathrm{e}-05 & 1 & \text { K.IEELQLIVNDK.S } \\ 0.1159 & 0 & 53 & 0.00016 & 1 & \text { K.NIDINDVTPNCR.V + Carbamidomethyl (C) }\end{array}$


Protein Name:

Gene name:

Taxonomy:

Swiss Prot No:

Mass:

Score:

Queries matched:
26S Protease regulatory subunit s10B (Proteasome subunit $\mathrm{p} 42$ )

\section{PSMC6}

Homo sapiens

P62333

44145

362

10

Summarized table of matched peptides:

$\begin{array}{llll}\text { Query } & \text { Observed } & \text { Mr(expt) } & \text { Mr(calc) } \\ 6 & 418.7894 & 835.5642 & 835.4916 \\ 15 & 467.3053 & 932.5960 & 932.5178 \\ 19 & 485.2583 & 968.5020 & 968.4199 \\ 21 & 504.7979 & 1007.5812 & 1007.5036 \\ 25 & 582.8313 & 1163.6480 & 1163.5571 \\ 27 & 610.3530 & 1218.6914 & 1218.6066 \\ 29 & 637.3812 & 1272.7478 & 1272.6350 \\ 34 & 683.3949 & 1364.7752 & 1364.6758 \\ 35 & 692.8710 & 1383.7274 & 1383.6275 \\ 41 & 899.5498 & 1797.0850 & 1796.9672\end{array}$

\begin{tabular}{llllll} 
Delta & Miss & Score & \multicolumn{2}{l}{ Expect Rank } & Peptide \\
& & & & & \\
0.0727 & 0 & 4 & 1.4 & 1 & K.IHAGPITK.H \\
0.0782 & 0 & 47 & 0.00031 & 1 & K.VVSSSIVDK.Y \\
0.0821 & 0 & 50 & 0.0004 & 1 & R.FSEGTSADR.E \\
0.0777 & 1 & 26 & 0.073 & 1 & R.DKALQDYR.K \\
0.0910 & 0 & 63 & $1.7 \mathrm{e}-05$ & 1 & K.LSDGFNGADLR.N \\
0.0848 & 0 & 31 & 0.027 & 1 & K.GCLLYGPPGTGK.T + Carbamidomethyl (C) \\
0.1129 & 0 & 31 & 0.021 & 1 & K.HGEIDYEAIVK.L \\
0.0995 & 0 & 61 & $2.7 \mathrm{e}-05$ & 1 & R.AVASQLDCNFLK.V + Carbamidomethyl (C) \\
0.1000 & 0 & 17 & 0.85 & 1 & R.NVCTEAGMFAIR.A + Carbamidomethyl (C) \\
0.1179 & 0 & 33 & 0.0057 & 1 & R.EVIELPLTNPELFQR.V
\end{tabular}


Protein Name:

Gene name:

Taxonomy:

Swiss Prot No:

Mass:

Score:

Queries matched:
Aconitate hydratase, mitochondrial precursor $\mathrm{ACO} 2$

Homo sapiens

Q99798

85372

177

08

Summarized table of matched peptides:

$\begin{array}{llll}\text { Query } & \text { Observed } & \text { Mr(expt) } & \text { Mr(calc) } \\ 4 & 400.7866 & 799.5586 & 799.5167 \\ 17 & 461.7712 & 921.5278 & 921.4668 \\ 18 & 468.2798 & 934.5450 & 934.4872 \\ 23 & 493.2851 & 984.5556 & 984.5029 \\ 24 & 501.8082 & 1001.6018 & 1001.5545 \\ 47 & 732.4156 & 1462.8166 & 1462.7416 \\ 50 & 533.9355 & 1598.7847 & 1598.7285 \\ 51 & 801.4456 & 1600.8766 & 1600.7845\end{array}$

Delta Miss Score Expect Rank Peptide

$\begin{array}{llllll}0.0420 & 0 & 1 & 12 & 1 & \text { K.VAGILTVK.G } \\ 0.0611 & 0 & 20 & 0.31 & 1 & \text { R.EHAALEPR.H } \\ 0.0578 & 0 & 22 & 0.2 & 1 & \text { R.DGYAQILR.D } \\ 0.0528 & 0 & 15 & 1 & 1 & \text { K.EGWPLDIR.V } \\ 0.0473 & 0 & 30 & 0.032 & 1 & \text { K.DFTPGKPLK.C } \\ 0.0751 & 0 & 25 & 0.087 & 1 & \text { K.SQFTITPGSEQIR.A } \\ 0.0562 & 0 & 23 & 0.2 & 1 & \text { K.DSSGQHVDVSPTSQR.L } \\ 0.0922 & 0 & 40 & 0.003 & 1 & \text { R.NAVTQEFGPVPDTAR.Y }\end{array}$


Protein Name:

Gene name:

Taxonomy:

Swiss Prot No:

Mass:

Score:

Queries matched:
ATP synthase subunit beta, mitochondrial precursor

ATP5B

Homo sapiens

$\mathrm{P} 06576$

56525

677

19

Summarized table of matched peptides:

$\begin{array}{llll}\text { Query } & \text { Observed } & \text { Mr(expt) } & \text { Mr(calc) } \\ 9 & 450.2942 & 898.5738 & 898.5123 \\ 11 & 488.3246 & 974.6346 & 974.5548 \\ 14 & 519.8387 & 1037.6628 & 1037.5869 \\ 20 & 544.8633 & 1087.7120 & 1087.6277 \\ 29 & 631.8668 & 1261.7190 & 1261.6336 \\ 30 & 639.8633 & 1277.7120 & 1277.6285 \\ 35 & 693.4084 & 1384.8022 & 1384.7020 \\ 37 & 701.4039 & 1400.7932 & 1400.6969 \\ 38 & 469.6003 & 1405.7791 & 1405.6738 \\ 39 & 718.4271 & 1434.8396 & 1434.7466 \\ 41 & 720.4430 & 1438.8714 & 1438.7820 \\ 43 & 729.4686 & 1456.9226 & 1456.8323 \\ 46 & 737.4821 & 1472.9496 & 1472.8272 \\ 57 & 801.4634 & 1600.9122 & 1600.8031 \\ 60 & 809.4618 & 1616.9090 & 1616.7980 \\ 62 & 826.0221 & 1650.0296 & 1649.9100 \\ 63 & 551.0172 & 1650.0298 & 1649.9100 \\ 76 & 994.5826 & 1987.1506 & 1987.0262 \\ 85 & 1149.6022 & 2297.1898 & 2297.0667\end{array}$

\section{Delta Miss Score Expect Rank Peptide}

$\begin{array}{lllll}0.0615 & 0 & 42 & 0.0012 & 1 \\ 0.0798 & 0 & 29 & 0.016 & 1 \\ 0.0759 & 0 & 44 & 0.00037 & 1 \\ 0.0843 & 0 & 46 & 0.00021 & 1 \\ 0.0855 & 0 & 41 & 0.0029 & 1 \\ 0.0835 & 0 & 37 & 0.0066 & 1 \\ 0.1003 & 0 & 37 & 0.0054 & 1 \\ 0.0963 & 0 & 35 & 0.0091 & 1 \\ 0.1053 & 0 & 21 & 0.25 & 1 \\ 0.0930 & 0 & 95 & 8.1 \mathrm{e}-09 & 1 \\ 0.0895 & 0 & 87 & 2.9 \mathrm{e}-08 & 1 \\ 0.0904 & 0 & 40 & 0.00096 & 1 \\ 0.1225 & 0 & 50 & 6.3 \mathrm{e}-05 & 1 \\ 0.1092 & 0 & 44 & 0.0012 & 1 \\ 0.1110 & 0 & 47 & 0.00056 & 1 \\ 0.1196 & 0 & 52 & 4.6 \mathrm{e}-05 & 1 \\ 0.1198 & 0 & 36 & 0.0023 & 1 \\ 0.1245 & 0 & 46 & 0.00043 & 1 \\ 0.1231 & 0 & 39 & 0.0033 & 1\end{array}$

K.VLDSGAPIK.I

K.IGLFGGAGVGK.T

K.IPVGPETLGR.I

K.VVDLLAPYAK.G

R.TIAMDGTEGLVR.G

R.TIAMDGTEGLVR.G + Oxidation (M)

R.IMNVIGEPIDER G

R.IMNVIGEPIDER.G + Oxidation (M)

K.AHGGYSVFAGVGER.T

R.FTQAGSEVSALLGR.I

R.VALTGLTVAEYFR.D

K.TVLIMELINNVAK.A

K.TVLIMELINNVAK.A + Oxidation (M)

K.VALVYGQMNEPPGAR.A

K.VALVYGQMNEPPGAR.A + Oxidation (M)

R.LVLEVAQHLGESTVR.T

R.LVLEVAQHLGESTVR.T

R.AIAELGIYPAVDPLDSTSR.I

R.IPSAVGYQPTLATDMGTMQER.I + 2 Oxidation (M) 
Protein Name:

Gene name:

Taxonomy:

Swiss Prot No:

Mass:

Score

Queries matched:
ATP synthase subunit alpha, mitochondrial precursor

\section{ATP5A1}

Homo sapiens

$\mathrm{P} 25705$

59714

141

07

Summarized table of matched peptides:

$\begin{array}{llll}\text { Query } & \text { Observed } & \text { Mr(expt) } & \text { Mr(calc) } \\ 6 & 423.2734 & 844.5322 & 844.5018 \\ 14 & 438.7756 & 875.5366 & 875.4899 \\ 20 & 500.8151 & 999.6156 & 999.5712 \\ 22 & 513.8162 & 1025.6178 & 1025.5869 \\ 25 & 586.3336 & 1170.6526 & 1170.6244 \\ 27 & 658.8932 & 1315.7718 & 1315.7347 \\ 29 & 812.9684 & 1623.9222 & 1623.8831\end{array}$

$\begin{array}{llllll}\text { Delta } & \text { Miss } & \text { Score } & \text { Expect Rank } & \text { Peptide } \\ 0.0305 & 0 & 14 & 1.2 & 1 & \text { R.STVAQLVK.R } \\ 0.0468 & 0 & 20 & 0.3 & 1 & \text { R.QMSLLLR.R + Oxidation (M) } \\ 0.0444 & 0 & 6 & 6.9 & 1 & \text { R.VLSIGDGIAR.V } \\ 0.0309 & 0 & 22 & 0.13 & 1 & \text { K.AVDSLVPIGR.G } \\ 0.0283 & 0 & 38 & 0.0062 & 1 & \text { R.VVDALGNAIDGK.G } \\ 0.0371 & 0 & 19 & 0.39 & 1 & \text { K.TSIAIDTINQK.R } \\ 0.0391 & 0 & 23 & 0.13 & 1 & \text { R.TGAIVDVPVGEELLGR.V }\end{array}$




\section{Protein Name:}

Gene name:

Taxonomy:

Swiss Prot No:

Mass:

Score:

Queries matched:
Fructose-bisphosphate aldolase A

\section{ALDOA}

Homo sapiens

$\mathrm{P} 04075$

39264

242

08

Summarized table of matched peptides:

\begin{tabular}{|c|c|c|c|c|c|c|c|c|c|}
\hline Query & Observed & $\operatorname{Mr}(\operatorname{expt})$ & $\operatorname{Mr}($ calc) & Delta & Miss & Score & Expect & t Rank & Peptide \\
\hline 3 & 401.2808 & 800.5470 & 800.4756 & 0.0715 & 0 & 12 & 0.81 & 1 & R.ALQASALK.A \\
\hline 13 & 464.2510 & 926.4874 & 926.4167 & 0.0707 & 0 & 4 & 13 & 1 & R.CQYVTEK.V + Carbamidomethyl (C) \\
\hline 20 & 522.8375 & 1043.6604 & 1043.5611 & 0.0993 & 0 & 39 & 0.0025 & 1 & R.QLLLTADDR.V \\
\hline 24 & 547.3272 & 1092.6398 & 1092.5563 & 0.0835 & 1 & 44 & 0.0011 & 1 & K.AAQEEYVKR.A \\
\hline 27 & 566.8320 & 1131.6494 & 1131.5706 & 0.0788 & 0 & 64 & $1.3 e-05$ & 1 & R.ALANSLACQGK.Y + Carbamidomethyl $(\mathrm{C})$ \\
\hline 34 & 666.9040 & 1331.7934 & 1331.6932 & 0.1002 & 0 & 47 & 0.00054 & +1 & K.GILAADESTGSIAK.R \\
\hline 37 & 717.9208 & 1433.8270 & 1433.7191 & 0.1080 & 0 & 32 & 0.015 & 1 & -.PYQYPALTPEQK.K \\
\hline 40 & 549.6471 & 1645.9195 & 1645.8019 & 0.1175 & 1 & 2 & 18 & 1 & R.LQSIGTENTEENRR.F \\
\hline
\end{tabular}


Protein Name:

Gene name:

Taxonomy:

Swiss Prot No:

Mass:

Score:

Queries matched:
Glyceraldehyde-3-phosphate dehydrogenase

\section{GAPDH}

Homo sapiens

P04406

35899

536

24

Summarized table of matched peptides:

\section{Query Observed $\operatorname{Mr}(\operatorname{expt})$}

$\begin{array}{lll}403.2310 & 804.4474 & 804.4242 \\ 403.2445 & 804.4744 & 804.4242 \\ 403.2482 & 804.4818 & 804.4242 \\ 403.2496 & 804.4846 & 804.4242 \\ 403.2508 & 804.4870 & 804.4242 \\ 403.2525 & 804.4904 & 804.4242 \\ 415.2531 & 828.4916 & 828.4341 \\ 435.2781 & 868.5416 & 868.5018 \\ 601.3527 & 1200.6908 & 1200.5995 \\ 706.4012 & 1410.7878 & 1410.7830 \\ 706.4482 & 1410.8818 & 1410.7830 \\ 706.4482 & 1410.8818 & 1410.7830 \\ 706.4504 & 1410.8862 & 1410.7830 \\ 706.4508 & 1410.8870 & 1410.7830 \\ 706.4528 & 1410.8910 & 1410.7830 \\ 706.4571 & 1410.8996 & 1410.7830 \\ 765.9047 & 1529.7948 & 1529.7871 \\ 765.9556 & 1529.8966 & 1529.7871 \\ 807.5146 & 1613.0146 & 1612.8936 \\ 882.4482 & 1762.8818 & 1762.7950 \\ 882.4657 & 1762.9168 & 1762.7950 \\ 882.4754 & 1762.9362 & 1762.7950 \\ 917.5035 & 1832.9924 & 1832.9124 \\ 1139.0968 & 2276.1790 & 2276.0306\end{array}$

Delta Miss Score Expect Rank Peptide

$\begin{array}{lllll}0.0233 & 0 & 33 & 0.022 & 1 \\ 0.0503 & 0 & 8 & 5.1 & 2 \\ 0.0577 & 0 & 25 & 0.097 & 1 \\ 0.0605 & 0 & 19 & 0.4 & 1 \\ 0.0629 & 0 & 14 & 1.1 & 1 \\ 0.0663 & 0 & 5 & 9.1 & 2 \\ 0.0576 & 0 & 17 & 0.83 & 1 \\ 0.0399 & 0 & 32 & 0.0082 & 1 \\ 0.0914 & 0 & 8 & 5.2 & 1 \\ 0.0048 & 0 & 57 & 5.4 \mathrm{e}-05 & 1 \\ 0.0988 & 0 & 22 & 0.07 & 1 \\ 0.0988 & 0 & 28 & 0.021 & 1 \\ 0.1032 & 0 & 27 & 0.023 & 1 \\ 0.1040 & 0 & 24 & 0.048 & 1 \\ 0.1080 & 0 & 32 & 0.0064 & 1 \\ 0.1166 & 0 & 5 & 3.3 & 1 \\ 0.0077 & 0 & 92 & 2.1 \mathrm{e}-08 & 1 \\ 0.1095 & 0 & 53 & 0.00013 & 1 \\ 0.1210 & 0 & 58 & 1.2 \mathrm{e}-05 & 1 \\ 0.0868 & 0 & 71 & 3.6 \mathrm{e}-06 & 1 \\ 0.1218 & 0 & 55 & 0.00012 & 1 \\ 0.1412 & 0 & 62 & 2.4 \mathrm{e}-05 & 1 \\ 0.0800 & 0 & 135 & 8.8 \mathrm{e}-13 & 1 \\ 0.1484 & 0 & 32 & 0.017 & 1\end{array}$

K.VGVNGFGR.I

K.VGVNGFGR.I

K.VGVNGFGR.I

K.VGVNGFGR.I

K.VGVNGFGR.I

K.VGVNGFGR.I

K.QASEGPLK.G

K.VIPELNGK.L

R.VVDLMAHMASK.E

R.GALQNIIPASTGAAK.A

R.GALQNIIPASTGAAK A

R.GALQNIIPASTGAAK.A

R.GALQNIIPASTGAAK.A

R.GALQNIIPASTGAAK A

R.GALQNIIPASTGAAK.A

R.GALQNIIPASTGAAK.A

R.VPTANVSVVDLTCR.L + Carbamidomethyl (C)

R.VPTANVSVVDLTCR.L + Carbamidomethyl (C)

K.LVINGNPITIFQER.D

K.LISWYDNEFGYSNR.V

K.LISWYDNEFGYSNR.V

K.LISWYDNEFGYSNR.V

K.IISNASCTTNCLAPLAK.V + 2 Carbamidomethyl (C)

K.WGDAGAEYVVESTGVFTTMEK.A 


\section{Protein Name:}

Gene name:

Taxonomy:

Swiss Prot No:

Mass:

Score:

Queries matched:
L-lactate dehydrogenase A chain

LDH-A

Homo sapiens

$\mathrm{P} 00338$

36534

349

08

Summarized table of matched peptides:

\begin{tabular}{|c|c|c|c|c|c|c|c|c|}
\hline Query & Observed & $\operatorname{Mr}(\operatorname{expt})$ & Mr(calc) & Delta & Miss & Score & Expect Rank & Peptide \\
\hline 14 & 457.3351 & 912.6556 & 912.5756 & 0.0800 & 0 & 38 & 0.000671 & K.LVIITAGAR.Q \\
\hline 15 & 465.3272 & 928.6398 & 928.5745 & 0.0653 & 0 & 8 & $0.99 \quad 1$ & K.FIIPNVVK.Y \\
\hline 19 & 506.2862 & 1010.5578 & 1010.4669 & 0.0910 & 0 & 49 & 0.000451 & K.DYNVTANSK.L \\
\hline 22 & 559.8436 & 1117.6726 & 1117.5768 & 0.0959 & 0 & 33 & $0.012 \quad 1$ & K.SADTLWGIQK.E \\
\hline 23 & 560.3669 & 1118.7192 & 1118.6335 & 0.0857 & 0 & 31 & $0.0083 \quad 1$ & K.DQLIYNLLK.E \\
\hline 24 & 567.8273 & 1133.6400 & 1133.5564 & 0.0837 & 0 & 56 & $9.3 e-05 \quad 1$ & K.VTLTSEEEAR.L \\
\hline 26 & 624.8496 & 1247.6846 & 1247.5928 & 0.0919 & 0 & 66 & $8.6 \mathrm{e}-061$ & R.VIGSGCNLDSAR.F + Carbamidomethyl (C) \\
\hline 27 & 632.8881 & 1263.7616 & 1263.6710 & 0.0906 & 0 & 69 & $2.2 \mathrm{e}-06 \quad 1$ & K.QVVESAYEVIK.L \\
\hline
\end{tabular}


Protein Name:

Gene name:

Taxonomy:

Swiss Prot No:

Mass:

Score:

Queries matched:
Pyruvate dehydrogenase E1 component subunit beta, mitochondrial precursor

Homo sapiens

P11177

39194

392

11

Summarized table of matched peptides:

$\begin{array}{llll}\text { Query } & \text { Observed } & \text { Mr(expt) } & \text { Mr(calc) } \\ 1 & 410.2821 & 818.5496 & 818.4902 \\ 10 & 451.8052 & 901.5958 & 901.5273 \\ 22 & 616.3432 & 1230.6718 & 1230.5880 \\ 24 & 628.3926 & 1254.7706 & 1254.6819 \\ 25 & 632.8622 & 1263.7098 & 1263.6169 \\ 27 & 676.3417 & 1350.6688 & 1350.5907 \\ 29 & 768.3867 & 1534.7588 & 1534.6569 \\ 38 & 882.4966 & 1762.9786 & 1762.8712 \\ 40 & 901.5106 & 1801.0066 & 1800.8933 \\ 41 & 922.5328 & 1843.0510 & 1842.9338 \\ 42 & 634.0153 & 1899.0241 & 1898.8787\end{array}$

$\begin{array}{lllll}\text { Delta } & \text { Miss } & \text { Score } & \text { Expect Ran } \\ 0.0595 & 0 & 8 & 1.2 & 2 \\ 0.0686 & 0 & 16 & 0.33 & 1 \\ 0.0838 & 0 & 29 & 0.05 & 1 \\ 0.0887 & 0 & 47 & 0.00034 & 1 \\ 0.0930 & 0 & 24 & 0.14 & 1 \\ 0.0781 & 0 & 32 & 0.021 & 1 \\ 0.1019 & 0 & 36 & 0.0087 & 1 \\ 0.1075 & 0 & 86 & 7.6 \mathrm{e}-08 & 1 \\ 0.1133 & 0 & 66 & 6.8 \mathrm{e}-06 & 1 \\ 0.1173 & 0 & 43 & 0.0013 & 1 \\ 0.1453 & 0 & 5 & 9 & 1\end{array}$

\section{Peptide}

K.DIIFAIK.K

K.DFLIPIGK.A

K.VVSPWNSEDAK.G

K.ILEDNSIPQVK.D

R.VTGADVPMPYAK.I + Oxidation (M)

K.EGVECEVINMR.T + Carbamidomethyl (C); Oxidation (M)

R.DAINQGMDEELER.D + Oxidation (M)

R.IMEGPAFNFLDAPAVR.V + Oxidation (M)

K.VFLLGEEVAQYDGAYK.V

K.TYYMSGGLQPVPIVFR.G + Oxidation (M)

R.TIRPMDMETIEASVMK.T + 3 Oxidation (M) 
Protein Name:

Gene name:

Taxonomy:

Swiss Prot No:

Mass:

Score:

Queries matched:
Pyruvate kinase, isoenzymes M1/M2 E1 component subunit beta, mitochondrial precursor PKM2

Homo sapiens

P14618

57769

690

15

Summarized table of matched peptides:

$\begin{array}{llll}\text { Query } & \text { Observed } & \text { Mr(expt) } & \text { Mr(calc) } \\ 12 & 442.7211 & 883.4276 & 883.4698 \\ 13 & 456.7120 & 911.4094 & 911.4461 \\ 14 & 477.2236 & 952.4326 & 952.4726 \\ 16 & 495.7355 & 989.4564 & 989.5029 \\ 18 & 510.2402 & 1018.4658 & 1018.5083 \\ 19 & 520.7584 & 1039.5022 & 1039.5410 \\ 22 & 559.7850 & 1117.5554 & 1117.5978 \\ 23 & 571.2844 & 1140.5542 & 1140.6026 \\ 25 & 597.3013 & 1192.5880 & 1192.6373 \\ 26 & 599.3040 & 1196.5934 & 1196.6401 \\ 27 & 607.2697 & 1212.5248 & 1212.5696 \\ 35 & 680.3224 & 1358.6302 & 1358.6976 \\ 38 & 731.8821 & 1461.7496 & 1461.8078 \\ 39 & 734.8108 & 1467.6070 & 1467.6704 \\ 41 & 818.9216 & 1635.8286 & 1635.8831 \\ 42 & 821.8513 & 1641.6880 & 1641.7634 \\ 44 & 882.9604 & 1763.9062 & 1763.9781 \\ 50 & 1088.0200 & 2174.0254 & 2174.1106\end{array}$

\section{Delta Miss Score Expect Rank Peptide}

$\begin{array}{lllll}-0.0421 & 0 & 23 & 0.16 & 1 \\ -0.0366 & 0 & 50 & 0.00027 & 1 \\ -0.0399 & 0 & 39 & 0.0047 & 1 \\ -0.0464 & 0 & 3 & 21 & 1 \\ -0.0425 & 0 & 1 & 34 & 1 \\ -0.0388 & 1 & 1 & 28 & 2 \\ -0.0424 & 1 & 62 & 2.7 \mathrm{e}-05 & 1 \\ -0.0484 & 0 & 28 & 0.063 & 1 \\ -0.0492 & 1 & 45 & 0.0014 & 1 \\ -0.0466 & 0 & 55 & 0.00013 & 1 \\ -0.0448 & 0 & 54 & 0.00012 & 1 \\ -0.0674 & 0 & 60 & 4 \mathrm{e}-05 & 1 \\ -0.0582 & 0 & 78 & 5.6 \mathrm{e}-07 & 1 \\ -0.0633 & 0 & 46 & 0.00055 & 1 \\ -0.0545 & 0 & 60 & 3.8 \mathrm{e}-05 & 1 \\ -0.0754 & 0 & 61 & 1.9 \mathrm{e}-05 & 1 \\ -0.0718 & 1 & 29 & 0.043 & 1 \\ -0.0852 & 0 & 90 & 2.6 \mathrm{e}-08 & 1\end{array}$

R.MQHLIAR.E + Oxidation (M)

K.ASDVHEVR.K

K.IENHEGVR.R

K.GSGTAEVELK.K

K.GDYPLEAVR.M

K.ASDVHEVRK.V

K.GSGTAEVELKK.G

R.GDLGIEIPAEK.V

R.SVETLKEMIK.S + Oxidation (M)

R.LDIDSPPITAR.N

K.ITLDNAYMEK.C + Oxidation (M)

R.NTGIICTIGPASR.S + Carbamidomethyl (C)

K.IYVDDGLISLQVK.Q

K.CDENILWLDYK.N + Carbamidomethyl (C)

K.GVNLPGAAVDLPAVSEK.D

K.DPVQEAWAEDVDLR.V

K.KGVNLPGAAVDLPAVSEK.D

R.LAPITSDPTEATAVGAVEASFK.C 
Protein Name:

Gene name:

\section{Taxonomy:}

Swiss Prot No:

Mass:

Score:

Queries matched:
Stress- 70 protein, mitochondria precursor ( 75 glucose regulated protein)

\section{HSPA9B}

Homo sapiens

P38646

73635

831

19

Summarized table of matched peptides:

$\begin{array}{lllllllll}\text { Query } & \text { Observed } & \text { Mr(expt) } & \text { Mr(calc) } & \text { Delta } & \text { Miss } & \text { Score } & \text { Expect Ram } \\ & & & & & & & & \\ 10 & 431.7600 & 861.5054 & 861.4443 & 0.0611 & 0 & 34 & 0.017 & 1 \\ 17 & 479.7805 & 957.5464 & 957.4879 & 0.0585 & 0 & 45 & 0.0011 & 1 \\ 18 & 490.2579 & 978.5012 & 978.4328 & 0.0685 & 0 & 3 & 22 & 1 \\ 20 & 497.2690 & 992.5234 & 992.4451 & 0.0784 & 0 & 10 & 4.7 & 1 \\ 23 & 575.3174 & 1148.6202 & 1148.5462 & 0.0741 & 1 & 26 & 0.098 & 1 \\ 25 & 616.3730 & 1230.7314 & 1230.6568 & 0.0747 & 0 & 85 & 8.3 \mathrm{e}-08 & 1 \\ 26 & 621.8849 & 1241.7552 & 1241.6727 & 0.0825 & 0 & 46 & 0.00053 & 1 \\ 27 & 645.8797 & 1289.7448 & 1289.6728 & 0.0721 & 0 & 56 & 7.9 \mathrm{e}-05 & 1 \\ 31 & 447.9034 & 1340.6884 & 1340.6109 & 0.0775 & 0 & 1 & 32 & 1 \\ 32 & 681.4254 & 1360.8362 & 1360.7350 & 0.1012 & 0 & 37 & 0.0026 & 1 \\ 33 & 725.9097 & 1449.8048 & 1449.7099 & 0.0949 & 0 & 73 & 1.5 \mathrm{e}-06 & 1 \\ 34 & 731.9410 & 1461.8674 & 1461.7497 & 0.1178 & 0 & 24 & 0.087 & 1 \\ 35 & 737.4470 & 1472.8794 & 1472.7834 & 0.0960 & 0 & 52 & 0.00012 & 1 \\ 36 & 784.9376 & 1567.8606 & 1567.7630 & 0.0976 & 0 & 53 & 0.00015 & 1 \\ 37 & 536.9615 & 1607.8627 & 1607.7613 & 0.1014 & 1 & 2 & 22 & 1 \\ 39 & 823.4917 & 1644.9688 & 1644.8722 & 0.0966 & 0 & 97 & 3.7 \mathrm{e}-09 & 1 \\ 40 & 847.9773 & 1693.9400 & 1693.8423 & 0.0977 & 0 & 24 & 0.11 & 1 \\ 42 & 905.0099 & 1808.0052 & 1807.8952 & 0.1101 & 0 & 92 & 1.7 \mathrm{e}-08 & 1 \\ 45 & 1028.5375 & 2055.0604 & 2054.9545 & 0.1060 & 0 & 71 & 2.2 \mathrm{e}-06 & 1\end{array}$

\author{
R.ETGVDLTK.D \\ K.VLENAEGAR.T \\ K.DDIENMVK.N + Oxidation (M) \\ R.YDDPEVQK.D \\ R.RYDDPEVQK.D \\ R.QAASSLQQASLK.L \\ K.DAGQISGLNVLR.V \\ K VQQTVQDLFGR A \\ R.ASNGDAWVEAHGK.L \\ R.AQFEGIVTDLIR.R \\ R.TTPSVVAFTADGER.L \\ K.SDIGEVILVGGMTR.M + Oxidation (M) \\ R.EQQIVIQSSGGLSK.D \\ R.QAVTNPNNTFYATK.R \\ K.MKETAENYLGHTAK.N + Oxidation (M) \\ R.VINEPTAAALAYGLDK.S \\ K.NAVITVPAYFNDSQR.Q \\ K.SQVFSTAADGQTQVEIK.V \\ K.STNGDTFLGGEDFDQALLR.H
}




$\begin{array}{ll}\text { Protein Name: } & \text { Superoxide dismutase }(\mathrm{Mn}) \\ \text { Gene name: } & \text { SOD2 } \\ \text { Taxonomy: } & \text { Homo sapiens } \\ \text { Swiss Prot No: } & \text { P04179 } \\ \text { Mass: } & 24707 \\ \text { Score: } & 34 \\ \text { Queries matched: } & 01\end{array}$

Summarized table of matched peptides:

$\begin{array}{llllllllll}\text { Query } & \text { Observed } & \text { Mr(expt) } & \text { Mr(calc) } & \text { Delta } & \text { Miss } & \text { Score } & \text { Expect Rank } & \text { Peptide } \\ 16 & 712.9363 & 1423.8580 & 1423.8034 & 0.0546 & 0 & 34 & 0.0059 & 1 & \text { K.GDVTAQIALQPALK.F }\end{array}$


Protein Name:

Gene name:

Taxonomy:

Swiss Prot No:

Mass:

Score:

Queries matched:
Ubiquinol-cytochrome-c reductase complex core protein I, mitochondrial precursor

\section{UQCRC1}

Homo sapiens

P31930

52612

135

06

Summarized table of matched peptides:

$\begin{array}{llll}\text { Query } & \text { Observed } & \text { Mr(expt) } & \text { Mr(calc) } \\ 1 & 405.2478 & 808.4810 & 808.4079 \\ 2 & 405.2639 & 808.5132 & 808.4443 \\ 13 & 486.3088 & 970.6030 & 970.5195 \\ 16 & 529.8335 & 1057.6524 & 1057.5767 \\ 18 & 662.3639 & 1322.7132 & 1322.6136 \\ 21 & 560.9692 & 1679.8858 & 1679.7573\end{array}$

\section{Delta Miss Score Expect Rank Peptide}

$\begin{array}{llllrl}0.0732 & 0 & 15 & 0.69 & 1 & \text { R.FTGSEIR.H } \\ 0.0690 & 0 & 10 & 1.4 & 1 & \text { R.SLLTYGR.R } \\ 0.0835 & 0 & 15 & 0.84 & 1 & \text { K.NRPGSALEK.E } \\ 0.0757 & 0 & 32 & 0.017 & 1 & \text { R.IAEVDASVVR.E } \\ 0.0996 & 0 & 60 & 3.8 \mathrm{e}-05 & 1 & \text { R.LCTSATESEVAR.G + Carbamidomethyl (C) } \\ 0.1285 & 0 & 6 & 9.4 & 1 & \text { K.EVESMGAHLNAYSTR.E + Oxidation (M) }\end{array}$


Protein Name:

Gene name:

Taxonomy:

Swiss Prot No:

Mass:

Score:

Queries matched:
Short chain 3-hydroxy-CoA dehydrogenase mitochondrial precursor

HADHSC

Homo sapiens

Q16836

34256

121

04

Summarized table of matched peptides:

$\begin{array}{llllllllll}\text { Query } & \text { Observed } & \text { Mr(expt) } & \text { Mr(calc) } & \text { Delta } & \text { Miss } & \text { Score } & \text { Expect Rank } & \text { Peptide } \\ 15 & 447.7512 & 893.4878 & 893.4130 & 0.0748 & 0 & 35 & 0.014 & 1 & \text { K.AGDEFVEK.T } \\ 16 & 466.3039 & 930.5932 & 930.5134 & 0.0799 & 1 & 7 & 4.1 & 1 & \text { K.KGIEESLR.K } \\ 19 & 509.8076 & 1017.6006 & 1017.5243 & 0.0763 & 0 & 33 & 0.015 & 1 & \text { K.DTPGFIVNR.L } \\ 22 & 586.8350 & 1171.6554 & 1171.5761 & 0.0794 & 0 & 48 & 0.00055 & 1 & \text { K.TFESLVDFSK.A }\end{array}$


Protein Name:

Gene name:

Taxonomy:

Swiss Prot No:

Mass:

Score:

Queries matched:
Alpha-2-HS-glycoprotein precursor (Fetuin-A)

AHSG

Homo sapiens

$\mathrm{P} 02765$

39300

149

04

Summarized table of matched peptides:

\begin{tabular}{|c|c|c|c|c|c|c|c|c|c|}
\hline Query & Observed & $\operatorname{Mr}(\operatorname{expt})$ & Mr(calc) & Delta & Miss & Score & Expect & Rank & Peptide \\
\hline 11 & 424.2310 & 846.4474 & 846.4269 & 0.0205 & 0 & 17 & 1 & 1 & K.CNLLAEK.Q + Carbamidomethyl (C) \\
\hline 32 & 669.2881 & 1336.5616 & 1336.5201 & 0.0415 & 0 & 65 & $9.4 \mathrm{e}-06$ & 1 & K.CDSSPDSAEDVR.K + Carbamidomethyl (C) \\
\hline 36 & 489.2238 & 1464.6496 & 1464.6151 & 0.0345 & 1 & 67 & $5.7 \mathrm{e}-06$ & 1 & K.CDSSPDSAEDVRK.V + Carbamidomethyl (C) \\
\hline 37 & 733.3438 & 1464.6730 & 1464.6151 & 0.0580 & 1 & 16 & 0.94 & 1 & K.CDSSPDSAEDVRK.V + Carbamidomethyl (C) \\
\hline
\end{tabular}


Protein Name:

Gene name:

Taxonomy:

Swiss Prot No:

Mass:

Score

Queries matched:
Ran-specific GTPase-activating protein (Ran-binding protein 1)

RANBP1

Homo sapiens

P43487

23296

283

07

Summarized table of matched peptides:

$\begin{array}{llll}\text { Query } & \text { Observed } & \operatorname{Mr}(\text { expt) } & \operatorname{Mr}(\text { calc) } \\ 16 & 485.2460 & 968.4774 & 968.4385 \\ 20 & 517.7781 & 1033.5416 & 1033.5192 \\ 21 & 517.7903 & 1033.5660 & 1033.5192 \\ 25 & 593.8829 & 1185.7512 & 1185.6968 \\ 34 & 668.3370 & 1334.6594 & 1334.6142 \\ 40 & 691.3442 & 1380.6738 & 1380.6296 \\ 56 & 984.2092 & 3932.8077 & 3932.7096\end{array}$

$\begin{array}{lllll}\text { Delta } & \text { Miss } & \text { Score } & \text { Expect Rar } \\ & & & & \\ 0.0389 & 1 & 14 & 1.5 & 1 \\ 0.0224 & 0 & 45 & 0.0015 & 1 \\ 0.0468 & 0 & 8 & 6.5 & 1 \\ 0.0544 & 1 & 24 & 0: 063 & 1 \\ 0.0452 & 0 & 87 & 8.5 \mathrm{e}-08 & 1 \\ 0.0442 & 0 & 99 & 4.5 \mathrm{e}-09 & 1 \\ 0.0981 & 0 & 14 & 0.51 & 1\end{array}$

Peptide

K.TKFEECR K + Carbamidomethyl $(\mathrm{C})$

R.FLNAENAQK.F

R.FLNAENAQK.F

K.VAEKLEALSVK.E

R.FASENDLPEWK.E

K.TLEEDEEELFK.M

K.DTHEDHDTSTENTDESNHDPQFEPIVSLPEQEIK.T 


\section{Protein Name:}

Gene name:

Taxonomy:

Swiss Prot No:

Mass:

Score:

Queries matched:
Rho-GDP-dissociation inhibitor 2

\section{ARHGDIB}

Homo sapiens

P52566

22843

121

04

Summarized table of matched peptides:

$\begin{array}{llllllllll}\text { Query } & \text { Observed } & \text { Mr(expt) } & \text { Mr(calc) } & \text { Delta } & \text { Miss } & \text { Score } & \text { Expect Rank } & \text { Peptide } \\ 5 & 428.2708 & 854.5270 & 854.4974 & 0.0297 & 0 & 41 & 0.0012 & 1 & \text { K.APNVVVTR.L } \\ 11 & 483.7654 & 965.5162 & 965.4719 & 0.0444 & 0 & 15 & 1.1 & 1 & \text { K.YVQHTYR.T } \\ 15 & 542.8330 & 1083.6514 & 1083.6077 & 0.0438 & 0 & 4 & 10 & 1 & \text { K.LNYKPPPQ.S } \\ 17 & 656.3851 & 1310.7556 & 1310.7081 & 0.0475 & 0 & 60 & 2.5 \mathrm{e}-05 & 1 & \text { K.TLLGDGPVVTDPK.A }\end{array}$


Protein Name:

Gene name:

Taxonomy:

Swiss Prot No:

Mass:

Score:

Queries matched:
Far upstream element-binding protein 1

FUBP1

Homo sapiens

Q96AE4

67431

268

09

Summarized table of matched peptides:

$\begin{array}{llll}\text { Query } & \text { Observed } & \text { Mr(expt) } & \text { Mr(calc) } \\ & & & \\ 13 & 436.7511 & 871.4876 & 871.4511 \\ 18 & 479.3060 & 956.5974 & 956.5542 \\ 20 & 509.7973 & 1017.5800 & 1017.5528 \\ 22 & 534.3174 & 1066.6202 & 1066.5771 \\ 23 & 574.8113 & 1147.6080 & 1147.5622 \\ 24 & 597.8048 & 1193.5950 & 1193.5499 \\ 28 & 668.8921 & 1335.7696 & 1335.7146 \\ 29 & 676.8860 & 1351.7574 & 1351.7095 \\ 30 & 501.9442 & 1502.8108 & 1502.7365\end{array}$

\section{Delta Miss Score Expect Rank Peptide}

$\begin{array}{ll}0.0365 & 0 \\ 0.0432 & 0 \\ 0.0272 & 0 \\ 0.0432 & 0 \\ 0.0459 & 0 \\ 0.0452 & 0 \\ 0.0550 & 0 \\ 0.0479 & 0 \\ 0.0743 & 0\end{array}$

$\begin{array}{lr}12 & 1 \\ 0.0029 & 1 \\ 3.2 & 1 \\ 0.00036 & 1 \\ 0.00072 & 1 \\ 20 & 1 \\ 1.2 \mathrm{e}-05 & 1 \\ 0.0038 & 1 \\ 3 & 1\end{array}$

K.IQNDAGVR.I

R.LLDQIVEK.G

K.EMVLELIR.D + Oxidation (M)

R.IAQITGPPDR.C

R.GTPQQIDYAR.Q

R.NPPPNADPNMK.L

R.IGGNEGIDVPIPR.F

K.IQIAPDSGGLPER.S

R.IQFKPDDGTTPER.I 


\section{BIBLIOGRAPHY}

Adams,J. (2004). The proteasome: a suitable antineoplastic target. Nat. Rev. Cancer 4, 349-360.

Ainsworth,S. and MacFarlane,N. (1973). A kinetic study of rabbit muscle pyruvate kinase. Biochem. J. 131, 223-236.

Al Ali,S.Y., Hassan,I.M., and Sadek,S. (2005). Ultrastructural changes in rat livers perfused in vitro and in vivo with a high dose of methotrexate. Histol. Histopathol. 20, 1131-1145.

Allegra,C.J., Drake,J.C., Jolivet,J., and Chabner,B.A. (1985). Inhibition of phosphoribosylaminoimidazolecarboxamide transformylase by methotrexate and dihydrofolic acid polyglutamates. Proc. Natl. Acad. Sci. U. S. A 82, 4881-4885.

Arselin,G., Giraud,M.F., Dautant,A., Vaillier,J., Brethes,D., Coulary-Salin,B., Schaeffer,J., and Velours,J. (2003). The GxxxG motif of the transmembrane domain of subunit $\mathrm{e}$ is involved in the dimerization/oligomerization of the yeast ATP synthase complex in the mitochondrial membrane. Eur. J. Biochem. 270, 1875-1884.

Babiak,R.M., Campello,A.P., Carnieri,E.G., and Oliveira,M.B. (1998). Methotrexate: pentose cycle and oxidative stress. Cell Biochem. Funct. 16, 283-293.

Bartek,J. and Lukas,J. (2001). Are all cancer genes equal? Nature 411, 1001-1002.

Baumgartner,B., Weber,M., Quirling,M., Fischer,C., Page,S., Adam,M., Von Schilling,C., Waterhouse,C., Schmid,C., Neumeier,D., and Brand,K. (2002). Increased IkappaB kinase activity is associated with activated NF-kappaB in acute myeloid blasts. Leukemia 16, 2062-2071.

Bedi,A., Barber,J.P., Bedi,G.C., el Deiry,W.S., Sidransky,D., Vala,M.S., Akhtar,A.J., Hilton,J., and Jones, R.J. (1995). BCR-ABL-mediated inhibition of apoptosis with delay of G2/M transition after DNA damage: a mechanism of resistance to multiple anticancer agents. Blood 86, 1148-1158.

Bedi,A., Zehnbauer,B.A., Barber,J.P., Sharkis,S.J., and Jones,R.J. (1994). Inhibition of apoptosis by BCR-ABL in chronic myeloid leukemia. Blood 83, 2038-2044.

Berggren,K.N., Chernokalskaya,E., Lopez,M.F., Beechem,J.M., and Patton,W.F. (2001). Comparison of three different fluorescent visualization strategies for detecting Escherichia coli ATP synthase subunits after sodium dodecyl sulfate-polyacrylamide gel electrophoresis. Proteomics. 1, 54-65.

Berlin,N.I., Rall,D., Mead,J.A., Freireich,E.J., Vanscott,E., Hertz,R., and Lipsett,M.B. (1963). Folic acid antagonist. Effects on the cell and the patient. Ccombined clinical staff conference at the National Institute of Health. Ann. Intern. Med. 59, 931-956. 
Bernardi,P., Scorrano,L., Colonna,R., Petronilli,V., and Di Lisa,F. (1999). Mitochondria and cell death. Mechanistic aspects and methodological issues. Eur. J. Biochem. 264, 687-701.

Birnie,G.D. (1988). The HL60 cell line: a model system for studying human myeloid cell differentiation. Br. J. Cancer Suppl 9, 41-45.

Blakley,R.L. and Sorrentino,B.P. (1998). In vitro mutations in dihydrofolate reductase that confer resistance to methotrexate: potential for clinical application. Hum. Mutat. 11, 259-263.

Bourgeois,B.F. (1988). Combination of valproate and ethosuximide: antiepileptic and neurotoxic interaction. J. Pharmacol. Exp. Ther. 247, 1128-1132.

Bradford,M.M. (1976). A rapid and sensitive method for the quantitation of microgram quantities of protein utilizing the principle of protein-dye binding. Anal. Biochem. 72, 248-254.

Braun,T., Carvalho,G., Coquelle,A., Vozenin,M.C., Lepelley,P., Hirsch,F., Kiladjian,J.J., Ribrag,V., Fenaux,P., and Kroemer,G. (2006). NF-kappaB constitutes a potential therapeutic target in high-risk myelodysplastic syndrome. Blood 107, 1156-1165.

Brengauz-Breitmann,M., Friedman,E., Savion,S., Torchinsky,A., Fein,A., and Toder,V. (2006). Involvement of NF-kappaB in the response of embryonic cells to methotrexate. Reprod. Toxicol. 22, 469-478.

Briviba,K., Roussyn,I., Sharov,V.S., and Sies,H. (1996). Attenuation of oxidation and nitration reactions of peroxynitrite by selenomethionine, selenocystine and ebselen. Biochem. J. 319 ( Pt 1), 13-15.

Bueso-Ramos,C.E., Rocha,F.C., Shishodia,S., Medeiros,L.J., Kantarjian,H.M., VadhanRaj,S., Estrov,Z., Smith,T.L., Nguyen,M.H., and Aggarwal,B.B. (2004). Expression of constitutively active nuclear-kappa B RelA transcription factor in blasts of acute myeloid leukemia. Hum. Pathol. 35, 246-253.

Bulteau,A.L., Verbeke,P., Petropoulos,I., Chaffotte,A.F., and Friguet,B. (2001). Proteasome inhibition in glyoxal-treated fibroblasts and resistance of glycated glucose-6phosphate dehydrogenase to $20 \mathrm{~S}$ proteasome degradation in vitro. J. Biol. Chem. 276, $45662-45668$.

Burnette,W.N. (1981). "Western blotting": electrophoretic transfer of proteins from sodium dodecyl sulfate--polyacrylamide gels to unmodified nitrocellulose and radiographic detection with antibody and radioiodinated protein A. Anal. Biochem. 112, 195-203.

Caetano,N.N., Campello,A.P., Carnieri,E.G., Kluppel,M.L., and Oliveira,M.B. (1997). Effect of methotrexate (MTX) on NAD(P)+ dehydrogenases of HeLa cells: malic enzyme, 2-oxoglutarate and isocitrate dehydrogenases. Cell Biochem. Funct. 15, 259-264.

Carpentier,Y., Desoize,B., Rollet,C., and Jardillier,J.C. (1978). [Effect of methotrexate on glycolysis of leukemia L 1210 cells cultivated in vitro]. C. R. Acad. Sci. Hebd. Seances Acad. Sci. D. 286, 375-377. 
Chen,Q., Vazquez,E.J., Moghaddas,S., Hoppel,C.L., and Lesnefsky,E.J. (2003). Production of reactive oxygen species by mitochondria: central role of complex III. J. Biol. Chem. 278, 36027-36031.

Chen,Z., Brand,N.J., Chen,A., Chen,S.J., Tong,J.H., Wang,Z.Y., Waxman,S., and Zelent,A. (1993). Fusion between a novel Kruppel-like zinc finger gene and the retinoic acid receptor-alpha locus due to a variant $\mathrm{t}(11 ; 17)$ translocation associated with acute promyelocytic leukaemia. EMBO J. 12, 1161-1167.

Choi,S.W. and Mason,J.B. (2000). Folate and carcinogenesis: an integrated scheme. J. Nutr. 130, 129-132.

Chou,W.C. and Dang,C.V. (2005). Acute promyelocytic leukemia: recent advances in therapy and molecular basis of response to arsenic therapies. Curr. Opin. Hematol. 12, 16.

Cline,M.J. (1994). The molecular basis of leukemia. N. Engl. J. Med. 330, 328-336.

Collins,S.J. (1987). The HL-60 promyelocytic leukemia cell line: proliferation, differentiation, and cellular oncogene expression. Blood 70, 1233-1244.

Collins,S.J., Gallo,R.C., and Gallagher,R.E. (1977). Continuous growth and differentiation of human myeloid leukaemic cells in suspension culture. Nature 270, 347349 .

Costello,R.T., Mallet,F., Gaugler,B., Sainty,D., Arnoulet,C., Gastaut,J.A., and Olive,D. (2000). Human acute myeloid leukemia CD34+/. Cancer Res. 60, 4403-4411.

Coux,O., Tanaka,K., and Goldberg,A.L. (1996). Structure and functions of the 20S and 26S proteasomes. Annu. Rev. Biochem. 65, 801-847.

Daley,G.Q., Van Etten,R.A., and Baltimore,D. (1990). Induction of chronic myelogenous leukemia in mice by the P210bcr/abl gene of the Philadelphia chromosome. Science 247, 824-830.

Desoize,B., Carpentier,Y., and Jardillier,J.C. (1978). Methotrexate induced alteration of glycolysis in L1210 cells in vitro. Biomedicine. 29, 58-60.

Dihazi,H., Asif,A.R., Agarwal,N.K., Doncheva,Y., and Muller,G.A. (2005). Proteomic analysis of cellular response to osmotic stress in thick ascending limb of Henle's loop (TALH) cells. Mol. Cell Proteomics. 4, 1445-1458.

Dive,C. and Hickman,J.A. (1991). Drug-target interactions: only the first step in the commitment to a programmed cell death? Br. J. Cancer 64, 192-196.

Dugan,L.L., Sensi,S.L., Canzoniero,L.M., Handran,S.D., Rothman,S.M., Lin,T.S., Goldberg,M.P., and Choi,D.W. (1995). Mitochondrial production of reactive oxygen species in cortical neurons following exposure to N-methyl-D-aspartate. J. Neurosci. 15, 6377-6388.

Evans,C.A., Tonge,R., Blinco,D., Pierce,A., Shaw,J., Lu,Y., Hamzah,H.G., Gray,A., Downes,C.P., Gaskell,S.J., Spooncer,E., and Whetton,A.D. (2004). Comparative 
proteomics of primitive hematopoietic cell populations reveals differences in expression of proteins regulating motility. Blood 103, 3751-3759.

Fadok,V.A., Voelker,D.R., Campbell,P.A., Cohen,J.J., Bratton,D.L., and Henson,P.M. (1992). Exposure of phosphatidylserine on the surface of apoptotic lymphocytes triggers specific recognition and removal by macrophages. J. Immunol. 148, 2207-2216.

Farber,S. (1950). Chemotherapeutic studies of tumors, including leukemia, in children. Am. J. Dis. Child 79, 961-962.

Frei,E., III, Blum,R.H., Pitman,S.W., Kirkwood,J.M., Henderson,I.C., Skarin,A.T., Mayer,R.J., Bast,R.C., Garnick,M.B., Parker,L.M., and Canellos,G.P. (1980). High dose methotrexate with leucovorin rescue. Rationale and spectrum of antitumor activity. Am. J. Med. 68, 370-376.

Fribley,A. and Wang,C.Y. (2006). Proteasome inhibitor induces apoptosis through induction of endoplasmic reticulum stress. Cancer Biol. Ther. 5, 745-748.

Fujii,K., Kondo,T., Yokoo,H., Yamada,T., Iwatsuki,K., and Hirohashi,S. (2005). Proteomic study of human hepatocellular carcinoma using two-dimensional difference gel electrophoresis with saturation cysteine dye. Proteomics. 5, 1411-1422.

Gallagher,R., Collins,S., Trujillo,J., McCredie,K., Ahearn,M., Tsai,S., Metzgar,R., Aulakh,G., Ting,R., Ruscetti,F., and Gallo,R. (1979). Characterization of the continuous, differentiating myeloid cell line (HL-60) from a patient with acute promyelocytic leukemia. Blood 54, 713-733.

Garber,K. (2006). Energy deregulation: licensing tumors to grow. Science 312, 1158 1159.

Genestier,L., Paillot,R., Quemeneur,L., Izeradjene,K., and Revillard,J.P. (2000). Mechanisms of action of methotrexate. Immunopharmacology 47, 247-257.

Gharahdaghi,F., Weinberg,C.R., Meagher,D.A., Imai,B.S., and Mische,S.M. (1999). Mass spectrometric identification of proteins from silver-stained polyacrylamide gel: a method for the removal of silver ions to enhance sensitivity. Electrophoresis 20, 601-605.

Giraud,M.F., Paumard,P., Soubannier,V., Vaillier,J., Arselin,G., Salin,B., Schaeffer,J., Brethes,D., di Rago,J.P., and Velours,J. (2002). Is there a relationship between the supramolecular organization of the mitochondrial ATP synthase and the formation of cristae? Biochim. Biophys. Acta 1555, 174-180.

Glickman,M.H. and Ciechanover,A. (2002). The ubiquitin-proteasome proteolytic pathway: destruction for the sake of construction. Physiol Rev. 82, 373-428.

Goker,E., Kheradpour,A., Waltham,M., Banerjee,D., Tong,W.P., Elisseyeff,Y., and Bertino,J.R. (1995). Acute monocytic leukemia: a myeloid leukemia subset that may be sensitive to methotrexate. Leukemia 9, 274-276.

Goldstein,D.P., Goldstein,P.R., Bottomley,P., Osathanondh,R., and Marean,A.R. (1976). Methotrexate with citrovorum factor rescue for nonmetastatic gestational trophoblastic neoplasms. Obstet. Gynecol. 48, 321-323. 
Gosalvez,M., Blanco,M., Hunter,J., Miko,M., and Chance,B. (1974). Effects of anticancer agents on the respiration of isolated mitochondria and tumor cells. Eur. J. Cancer 10, 567574.

Gougopoulou,D.M., Kiaris,H., Ergazaki,M., Anagnostopoulos,N.I., Grigoraki,V., and Spandidos,D.A. (1996). Mutations and expression of the ras family genes in leukemias. Stem Cells 14, 725-729.

Groth,O., Molin,L., and Thomsen,K. (1979). Tumour stage of mycosis fungoides treated with bleomycin and methotrexate: report from the Scandinavian mycosis fungoides study group. Acta Derm. Venereol. 59, 59-63.

Grumont,R.J., Rourke,I.J., O'Reilly,L.A., Strasser,A., Miyake,K., Sha,W., and Gerondakis,S. (1998). B lymphocytes differentially use the Rel and nuclear factor kappaB1 (NF-kappaB1) transcription factors to regulate cell cycle progression and apoptosis in quiescent and mitogen-activated cells. J. Exp. Med. 187, 663-674.

Grundler,R., Miething,C., Thiede,C., Peschel,C., and Duyster,J. (2005). FLT3-ITD and tyrosine kinase domain mutants induce 2 distinct phenotypes in a murine bone marrow transplantation model. Blood 105, 4792-4799.

Grune,T., Reinheckel,T., and Davies,K.J. (1996). Degradation of oxidized proteins in K562 human hematopoietic cells by proteasome. J. Biol. Chem. 271, 15504-15509.

Guzman,M.L., Neering,S.J., Upchurch,D., Grimes,B., Howard,D.S., Rizzieri,D.A., Luger,S.M., and Jordan,C.T. (2001). Nuclear factor-kappaB is constitutively activated in primitive human acute myelogenous leukemia cells. Blood 98, 2301-2307.

Hancock,J.F., Magee,A.I., Childs,J.E., and Marshall,C.J. (1989). All ras proteins are polyisoprenylated but only some are palmitoylated. Cell 57, 1167-1177.

Henderson,L.M. and Chappell,J.B. (1993). Dihydrorhodamine 123: a fluorescent probe for superoxide generation? Eur. J. Biochem. 217, 973-980.

Hershko,A. and Ciechanover,A. (1998). The ubiquitin system. Annu. Rev. Biochem. 67, 425-479.

Homesley,H.D., Blessing,J.A., Rettenmaier,M., Capizzi,R.L., Major,F.J., and Twiggs,L.B. (1988). Weekly intramuscular methotrexate for nonmetastatic gestational trophoblastic disease. Obstet. Gynecol. 72, 413-418.

Houstek,J., Pickova,A., Vojtiskova,A., Mracek,T., Pecina,P., and Jesina,P. (2006). Mitochondrial diseases and genetic defects of ATP synthase. Biochim. Biophys. Acta $1757,1400-1405$.

Huang,C.C., Hsu,P.C., Hung,Y.C., Liao,Y.F., Liu,C.C., Hour,C.T., Kao,M.C., Tsay,G.J., Hung,H.C., and Liu,G.Y. (2005). Ornithine decarboxylase prevents methotrexate-induced apoptosis by reducing intracellular reactive oxygen species production. Apoptosis. 10, 895-907. 
Hunger,S.P. (1996). Chromosomal translocations involving the E2A gene in acute lymphoblastic leukemia: clinical features and molecular pathogenesis. Blood 87, 12111224.

Ichiki,H., Sakurada,H., Kamo,N., Takahashi,T.A., and Sekiguchi,S. (1994). Generation of active oxygens, cell deformation and membrane potential changes upon UV-B irradiation in human blood cells. Biol. Pharm. Bull. 17, 1065-1069.

Ikeda,A., Shankar,D.B., Watanabe,M., Tamanoi,F., Moore,T.B., and Sakamoto,K.M. (2006). Molecular targets and the treatment of myeloid leukemia. Mol. Genet. Metab 88, 216-224.

Kaltenbach,J.P., Kaltenbach,M.H., and Lyons,W.B. (1958). Nigrosin as a dye for differentiating live and dead ascites cells. Exp. Cell Res. 15, 112-117.

Kaminskas,E. and Nussey,A.C. (1978). Effects of methotrexate and of environmental factors on glycolysis and metabolic energy state in cultured Ehrlich ascites carcinoma cells. Cancer Res. 38, 2989-2996.

Karin,M. (2006). Nuclear factor-kappaB in cancer development and progression. Nature $441,431-436$.

Kaufman,R.J. (2002). Orchestrating the unfolded protein response in health and disease. J. Clin. Invest 110, 1389-1398.

Kim,J.W. and Dang,C.V. (2005). Multifaceted roles of glycolytic enzymes. Trends Biochem. Sci. 30, 142-150.

Kisselev,A.F. and Goldberg,A.L. (2001). Proteasome inhibitors: from research tools to drug candidates. Chem. Biol. 8, 739-758.

Kondo,T., Seike,M., Mori,Y., Fujii,K., Yamada,T., and Hirohashi,S. (2003). Application of sensitive fluorescent dyes in linkage of laser microdissection and two-dimensional gel electrophoresis as a cancer proteomic study tool. Proteomics. 3, 1758-1766.

Koopman,G., Reutelingsperger,C.P., Kuijten,G.A., Keehnen,R.M., Pals,S.T., and van Oers,M.H. (1994). Annexin V for flow cytometric detection of phosphatidylserine expression on B cells undergoing apoptosis. Blood 84, 1415-1420.

Krause,D.S. and Van Etten,R.A. (2005). Tyrosine kinases as targets for cancer therapy. N. Engl. J. Med. 353, 172-187.

Kroemer,G., Dallaporta,B., and Resche-Rigon,M. (1998). The mitochondrial death/life regulator in apoptosis and necrosis. Annu. Rev. Physiol 60, 619-642.

Kroemer,G., el Deiry,W.S., Golstein,P., Peter,M.E., Vaux,D., Vandenabeele,P., Zhivotovsky,B., Blagosklonny,M.V., Malorni,W., Knight,R.A., Piacentini,M., Nagata,S., and Melino,G. (2005). Classification of cell death: recommendations of the Nomenclature Committee on Cell Death. Cell Death. Differ. 12 Suppl 2, 1463-1467. 
Kumatori,A., Tanaka,K., Inamura,N., Sone,S., Ogura,T., Matsumoto,T., Tachikawa,T., Shin,S., and Ichihara,A. (1990). Abnormally high expression of proteasomes in human leukemic cells. Proc. Natl. Acad. Sci. U. S. A 87, 7071-7075.

Laemmli,U.K. (1970). Cleavage of structural proteins during the assembly of the head of bacteriophage T4. Nature 227, 680-685.

Levine,M.N., Pritchard,K.I., Bramwell,V.H., Shepherd,L.E., Tu,D., and Paul,N. (2005). Randomized trial comparing cyclophosphamide, epirubicin, and fluorouracil with cyclophosphamide, methotrexate, and fluorouracil in premenopausal women with nodepositive breast cancer: update of National Cancer Institute of Canada Clinical Trials Group Trial MA5. J. Clin. Oncol. 23, 5166-5170.

Levis,M. and Small,D. (2003). Novel FLT3 tyrosine kinase inhibitors. Expert. Opin. Investig. Drugs 12, 1951-1962.

Leymarie,V., Galoisy,A.C., Falkenrodt,A., and Lessard,M. (2004). [Diagnosis of myeloid hematologic malignancies: contributions of the 2001 World Health Organization (WHO) classification]. Ann. Biol. Clin. (Paris) 62, 513-520.

Lim,L.C., Heng,K.K., Vellupillai,M., Tan,L.T., Boey,B.C., Lau,L.C., and How,G.F. (1999). Molecular and phenotypic spectrum of de novo Philadelphia positive acute leukemia. Int. J. Mol. Med. 4, 665-667.

Liu,P., Tarle,S.A., Hajra,A., Claxton,D.F., Marlton,P., Freedman,M., Siciliano,M.J., and Collins,F.S. (1993). Fusion between transcription factor CBF beta/PEBP2 beta and a myosin heavy chain in acute myeloid leukemia. Science 261, 1041-1044.

Look,A.T. (1997). Oncogenic transcription factors in the human acute leukemias. Science 278, 1059-1064.

Lopez-Terrada,D. (2006). Integrating the diagnosis of childhood malignancies. Adv. Exp. Med. Biol. 587, 121-137.

Maeda,K., Finnie,C., and Svensson,B. (2004). Cy5 maleimide labelling for sensitive detection of free thiols in native protein extracts: identification of seed proteins targeted by barley thioredoxin h isoforms. Biochem. J. 378, 497-507.

Majumdar,S. and Aggarwal,B.B. (2001). Methotrexate suppresses NF-kappaB activation through inhibition of IkappaBalpha phosphorylation and degradation. J. Immunol. 167, 2911-2920.

Martin,S.J., Reutelingsperger,C.P., McGahon,A.J., Rader,J.A., van Schie,R.C., LaFace,D.M., and Green,D.R. (1995). Early redistribution of plasma membrane phosphatidylserine is a general feature of apoptosis regardless of the initiating stimulus: inhibition by overexpression of Bcl-2 and Abl. J. Exp. Med. 182, 1545-1556.

Matthews,D.A., Bolin,J.T., Burridge,J.M., Filman,D.J., Volz,K.W., Kaufman,B.T., Beddell,C.R., Champness,J.N., Stammers,D.K., and Kraut,J. (1985). Refined crystal structures of Escherichia coli and chicken liver dihydrofolate reductase containing bound trimethoprim. J. Biol. Chem. 260, 381-391. 
McDonald,P.P., Bald,A., and Cassatella,M.A. (1997). Activation of the NF-kappaB pathway by inflammatory stimuli in human neutrophils. Blood 89, 3421-3433.

Moreno,I., Martin,G., Bolufer,P., Barragan,E., Rueda,E., Roman,J., Fernandez,P., Leon,P., Mena,A., Cervera,J., Torres,A., and Sanz,M.A. (2003). Incidence and prognostic value of FLT3 internal tandem duplication and D835 mutations in acute myeloid leukemia. Haematologica 88, 19-24.

Morgan,M.A., Ganser,A., and Reuter,C.W. (2003). Therapeutic efficacy of prenylation inhibitors in the treatment of myeloid leukemia. Leukemia 17, 1482-1498.

Mori,K. (2000). Tripartite management of unfolded proteins in the endoplasmic reticulum. Cell 101, 451-454.

Morrissey,J.H. (1981). Silver stain for proteins in polyacrylamide gels: a modified procedure with enhanced uniform sensitivity. Anal. Biochem. 117, 307-310.

Murphy,K.M., Levis,M., Hafez,M.J., Geiger,T., Cooper,L.C., Smith,B.D., Small,D., and Berg,K.D. (2003). Detection of FLT3 internal tandem duplication and D835 mutations by a multiplex polymerase chain reaction and capillary electrophoresis assay. J. Mol. Diagn. $5,96-102$.

Naito,S., Koga,H., Yokomizo,A., Sakamoto,N., Kotoh,S., Nakashima,M., Kiue,A., and Kuwano,M. (2000). Molecular analysis of mechanisms regulating drug sensitivity and the development of new chemotherapy strategies for genitourinary carcinomas. World J. Surg. 24, 1183-1186.

Neri,A., Chang,C.C., Lombardi,L., Salina,M., Corradini,P., Maiolo,A.T., Chaganti,R.S., and Dalla-Favera,R. (1991). B cell lymphoma-associated chromosomal translocation involves candidate oncogene lyt-10, homologous to NF-kappa B p50. Cell 67, 1075-1087.

Neri,A., Knowles,D.M., Greco,A., McCormick,F., and Dalla-Favera,R. (1988). Analysis of RAS oncogene mutations in human lymphoid malignancies. Proc. Natl. Acad. Sci. U. S. A $85,9268-9272$.

Neuhoff,V., Arold,N., Taube,D., and Ehrhardt,W. (1988). Improved staining of proteins in polyacrylamide gels including isoelectric focusing gels with clear background at nanogram sensitivity using Coomassie Brilliant Blue G-250 and R-250. Electrophoresis 9, 255-262.

Nicoletti,I., Migliorati,G., Pagliacci,M.C., Grignani,F., and Riccardi,C. (1991). A rapid and simple method for measuring thymocyte apoptosis by propidium iodide staining and flow cytometry. J. Immunol. Methods 139, 271-279.

Nishiyama,M., Yamamoto,W., Park,J.S., Okamoto,R., Hanaoka,H., Takano,H., Saito,N., Matsukawa,M., Shirasaka,T., and Kurihara,M. (1999). Low-dose cisplatin and 5fluorouracil in combination can repress increased gene expression of cellular resistance determinants to themselves. Clin. Cancer Res. 5, 2620-2628.

Obeng,E.A., Carlson,L.M., Gutman,D.M., Harrington,W.J., Jr., Lee,K.P., and Boise,L.H. (2006). Proteasome inhibitors induce a terminal unfolded protein response in multiple myeloma cells. Blood 107, 4907-4916. 
Oliveira,M.B., Campello,A.P., and Kluppel,W.L. (1989). Methotrexate: studies on cellular metabolism. III.--Effect on the transplasma-membrane redox activity and on ferricyanide-induced proton extrusion by HeLa cells. Cell Biochem. Funct. 7, 135-137.

Padua,R.A., Guinn,B.A., Al Sabah,A.I., Smith,M., Taylor,C., Pettersson,T., Ridge,S., Carter,G., White,D., Oscier,D., Chevret,S., and West,R. (1998). RAS, FMS and p53 mutations and poor clinical outcome in myelodysplasias: a 10-year follow-up. Leukemia $12,887-892$.

Paumard,P., Vaillier,J., Coulary,B., Schaeffer,J., Soubannier,V., Mueller,D.M., Brethes,D., di Rago,J.P., and Velours,J. (2002). The ATP synthase is involved in generating mitochondrial cristae morphology. EMBO J. 21, 221-230.

Perkins,D.N., Pappin,D.J., Creasy,D.M., and Cottrell,J.S. (1999). Probability-based protein identification by searching sequence databases using mass spectrometry data. Electrophoresis 20, 3551-3567.

Perrotti,D. and Calabretta,B. (2004). Translational regulation by the $\mathrm{p} 210 \mathrm{BCR} / \mathrm{ABL}$ oncoprotein. Oncogene 23, 3222-3229.

Phillips,D.C., Woollard,K.J., and Griffiths,H.R. (2003). The anti-inflammatory actions of methotrexate are critically dependent upon the production of reactive oxygen species. $\mathrm{Br}$. J. Pharmacol. 138, 501-511.

Pomerantz,J.L. and Baltimore,D. (2002). Two pathways to NF-kappaB. Mol. Cell 10, 693-695.

Pyatt,D.W., Stillman,W.S., Yang,Y., Gross,S., Zheng,J.H., and Irons,R.D. (1999). An essential role for NF-kappaB in human CD34(+) bone marrow cell survival. Blood 93, 3302-3308.

Reed,J.C. (2003). Apoptosis-targeted therapies for cancer. Cancer Cell 3, 17-22.

Reinecke,P., Schmitz,M., Schneider,E.M., Gabbert,H.E., and Gerharz,C.D. (2000). Multidrug resistance phenotype and paclitaxel (Taxol) sensitivity in human renal carcinoma cell lines of different histologic types. Cancer Invest 18, 614-625.

Rodriguez-Viciana,P., Warne,P.H., Dhand,R., Vanhaesebroeck,B., Gout,I., Fry,M.J., Waterfield,M.D., and Downward,J. (1994). Phosphatidylinositol-3-OH kinase as a direct target of Ras. Nature 370, 527-532.

Ron,D. (2002). Translational control in the endoplasmic reticulum stress response. J. Clin. Invest 110, 1383-1388.

Rosse,T., Olivier,R., Monney,L., Rager,M., Conus,S., Fellay,I., Jansen,B., and Borner,C. (1998). Bcl-2 prolongs cell survival after Bax-induced release of cytochrome c. Nature 391, 496-499.

Rots,M.G., Pieters,R., Jansen,G., Kaspers,G.J., Van Zantwijk,C.H., Noordhuis,P., Voorn,D.A., Van Wering,E.R., Creutzig,U., Veerman,A.J., and Peters,G.J. (2001). A possible role for methotrexate in the treatment of childhood acute myeloid leukaemia, in particular for acute monocytic leukaemia. Eur. J. Cancer 37, 492-498. 
Sachs,L. and Lotem,J. (1993). Control of programmed cell death in normal and leukemic cells: new implications for therapy. Blood 82, 15-21.

Sant,M.E., Lyons,S.D., Phillips,L., and Christopherson,R.I. (1992). Antifolates induce inhibition of amido phosphoribosyltransferase in leukemia cells. J. Biol. Chem. 267, 11038-11045.

Sawyers,C.L. (1992). The bcr-abl gene in chronic myelogenous leukaemia. Cancer Surv. $15,37-51$.

Schulte-Hermann,R., Bursch,W., Marian,B., and Grasl-Kraupp,B. (1999). Active cell death (apoptosis) and cellular proliferation as indicators of exposure to carcinogens. IARC Sci. Publ. 273-285.

Schweitzer,B.I., Srimatkandada,S., Gritsman,H., Sheridan,R., Venkataraghavan,R., and Bertino,J.R. (1989). Probing the role of two hydrophobic active site residues in the human dihydrofolate reductase by site-directed mutagenesis. J. Biol. Chem. 264, 20786-20795.

Shaw,J., Rowlinson,R., Nickson,J., Stone,T., Sweet,A., Williams,K., and Tonge,R. (2003). Evaluation of saturation labelling two-dimensional difference gel electrophoresis fluorescent dyes. Proteomics. 3, 1181-1195.

Smiley,S.T., Reers,M., Mottola-Hartshorn,C., Lin,M., Chen,A., Smith,T.W., Steele,G.D., Jr., and Chen,L.B. (1991). Intracellular heterogeneity in mitochondrial membrane potentials revealed by a J-aggregate-forming lipophilic cation JC-1. Proc. Natl. Acad. Sci. U. S. A $88,3671-3675$.

Soubannier,V., Vaillier,J., Paumard,P., Coulary,B., Schaeffer,J., and Velours,J. (2002). In the absence of the first membrane-spanning segment of subunit 4(b), the yeast ATP synthase is functional but does not dimerize or oligomerize. J. Biol. Chem. 277, 1073910745.

Souhami,R.L., Craft,A.W., Van der Eijken,J.W., Nooij,M., Spooner,D., Bramwell,V.H., Wierzbicki,R., Malcolm,A.J., Kirkpatrick,A., Uscinska,B.M., Van Glabbeke,M., and Machin,D. (1997). Randomised trial of two regimens of chemotherapy in operable osteosarcoma: a study of the European Osteosarcoma Intergroup. Lancet 350, 911-917.

Stone,R.M. (2002). Treatment of acute myeloid leukemia: state-of-the-art and future directions. Semin. Hematol. 39, 4-10.

Stone,S.R. and Morrison,J.F. (1986). Mechanism of inhibition of dihydrofolate reductases from bacterial and vertebrate sources by various classes of folate analogues. Biochim. Biophys. Acta 869, 275-285.

Takimoto,C.H. and Allegra,C.J. (1995). New antifolates in clinical development. Oncology (Williston. Park) 9, 649-56, 659.

Tergaonkar,V. (2006). NFkappaB pathway: a good signaling paradigm and therapeutic target. Int. J. Biochem. Cell Biol. 38, 1647-1653.

Thiede,C., Steudel,C., Mohr,B., Schaich,M., Schakel,U., Platzbecker,U., Wermke,M., Bornhauser,M., Ritter,M., Neubauer,A., Ehninger,G., and Illmer,T. (2002). Analysis of 
FLT3-activating mutations in 979 patients with acute myelogenous leukemia: association with FAB subtypes and identification of subgroups with poor prognosis. Blood 99, 43264335.

Tsujimoto,Y., Cossman,J., Jaffe,E., and Croce,C.M. (1985). Involvement of the bcl-2 gene in human follicular lymphoma. Science 228, 1440-1443.

Van Etten,R.A. and Shannon,K.M. (2004). Focus on myeloproliferative diseases and myelodysplastic syndromes. Cancer Cell 6, 547-552.

Voges,D., Zwickl,P., and Baumeister,W. (1999). The 26S proteasome: a molecular machine designed for controlled proteolysis. Annu. Rev. Biochem. 68, 1015-1068.

Wallace,D.C. (2005). Mitochondria and cancer: Warburg addressed. Cold Spring Harb. Symp. Quant. Biol. 70, 363-374.

Wang,C.Y., Cusack,J.C., Jr., Liu,R., and Baldwin,A.S., Jr. (1999). Control of inducible chemoresistance: enhanced anti-tumor therapy through increased apoptosis by inhibition of NF-kappaB. Nat. Med. 5, 412-417.

Wang,J., Hoshino,T., Redner,R.L., Kajigaya,S., and Liu,J.M. (1998). ETO, fusion partner in $\mathrm{t}(8 ; 21)$ acute myeloid leukemia, represses transcription by interaction with the human N-CoR/mSin3/HDAC1 complex. Proc. Natl. Acad. Sci. U. S. A 95, 10860-10865.

Wang,Q., Stacy,T., Miller,J.D., Lewis,A.F., Gu,T.L., Huang,X., Bushweller,J.H., Bories,J.C., Alt,F.W., Ryan,G., Liu,P.P., Wynshaw-Boris,A., Binder,M., MarinPadilla,M., Sharpe,A.H., and Speck,N.A. (1996). The CBFbeta subunit is essential for CBFalpha2 (AML1) function in vivo. Cell 87, 697-708.

Whitehead,V.M., Shuster,J.J., Vuchich,M.J., Mahoney,D.H., Jr., Lauer,S.J., Payment,C., Koch,P.A., Cooley,L.D., Look,A.T., Pullen,D.J., and Camitta,B. (2005). Accumulation of methotrexate and methotrexate polyglutamates in lymphoblasts and treatment outcome in children with B-progenitor-cell acute lymphoblastic leukemia: a Pediatric Oncology Group study. Leukemia 19, 533-536.

Winter,S.S., Holdsworth,M.T., Devidas,M., Raisch,D.W., Chauvenet,A., Ravindranath,Y., Ducore,J.M., and Amylon,M.D. (2006). Antimetabolite-based therapy in childhood T-cell acute lymphoblastic leukemia: a report of POG study 9296. Pediatr. Blood Cancer 46, 179-186.

Winter-Vann,A.M. and Casey,P.J. (2005). Post-prenylation-processing enzymes as new targets in oncogenesis. Nat. Rev. Cancer 5, 405-412.

Winter-Vann,A.M., Kamen,B.A., Bergo,M.O., Young,S.G., Melnyk,S., James,S.J., and Casey,P.J. (2003). Targeting Ras signaling through inhibition of carboxyl methylation: an unexpected property of methotrexate. Proc. Natl. Acad. Sci. U. S. A 100, 6529-6534.

Yamamoto,Y., Kiyoi,H., Nakano,Y., Suzuki,R., Kodera,Y., Miyawaki,S., Asou,N., Kuriyama,K., Yagasaki,F., Shimazaki,C., Akiyama,H., Saito,K., Nishimura,M., Motoji,T., Shinagawa,K., Takeshita,A., Saito,H., Ueda,R., Ohno,R., and Naoe,T. (2001). Activating mutation of D835 within the activation loop of FLT3 in human hematologic malignancies. Blood 97, 2434-2439. 
Yergeau,D.A., Hetherington,C.J., Wang,Q., Zhang,P., Sharpe,A.H., Binder,M., MarinPadilla,M., Tenen,D.G., Speck,N.A., and Zhang,D.E. (1997). Embryonic lethality and impairment of haematopoiesis in mice heterozygous for an AML1-ETO fusion gene. Nat. Genet. 15, 303-306.

Zamai,L., Falcieri,E., Zauli,G., Cataldi,A., and Vitale,M. (1993). Optimal detection of apoptosis by flow cytometry depends on cell morphology. Cytometry 14, 891-897.

Zamzami,N., Marchetti,P., Castedo,M., Zanin,C., Vayssiere,J.L., Petit,P.X., and Kroemer,G. (1995). Reduction in mitochondrial potential constitutes an early irreversible step of programmed lymphocyte death in vivo. J. Exp. Med. 181, 1661-1672.

Zhang,M.Y., Sun,S.C., Bell,L., and Miller,B.A. (1998). NF-kappaB transcription factors are involved in normal erythropoiesis. Blood 91, 4136-4144. 


\section{ACKNOWLEDGEMENT}

I take this occasion to express my deepest sense of gratitude to my supervisor, Prof. Dr. Gerhard Anton Mueller for his valuable guidance throughout the course of my work. His moral support always canalized me to achieve my goals. I will always cherish his informal and open discussions. I am grateful for his constructive discussions, which have helped me enormously. Without his help, it would have been very difficult to achieve my target.

Words would not suffice to record my profound and deepest sense of gratitude to my revered cosupervisor and mentor, Dr. Hassan Dihazi. It was his simple, humble, encouraging, approachable and understanding nature that gave me an impetus to face life boldly. His heuristic training made me independent and enabled me to accept the hard facts of life courageously during the toughest and most despicable moments of my doctoral work.

I am deeply indebted to Prof Dr. Gerhard Burckhardt Director, Abteilung Vegetative Physiologie und Pathophysiologie, Georg-August-Universitat Goettingen, for allowing me to pursue my doctorate in the Graduiertenkolleg 335.

I express my profound feelings of gratitude to Prof. Ruediger Hardeland who inspired me to carry out my work with positive determination. I am deeply indebted to Prof. Dr. Detlef Doenecke, Professor Dr. Ralf Ficner, PD Dr. Karen Hirsch-Ernst, Prof. Dr. Dieter Heineke and Prof. Dr. Ernst Wimmer for their valuable suggestions throughout the course of my work. I would be failing in my duty if I do not express my gratefulness to Dr Johannas Wessels who always rendered helpful suggestions. I sincerely thank Dr. Abdul Rahman Asif for giving me kind support whenever possible.

I acknowledge Jan Hendrick Streich, as he has always been a pillar of support to me. I was very lucky to have a colleague who was more than a friend to me. He has always helped me in all odd situations. I fathomably acknowledge the time-to-time help and kind co-operation extended to me by Nadeem Sheikh. 
I express my sincere thanks to Elke Brunst-Knoblich, Sophia Garten, S. Boguscha and Jens Mahrt whose constant support helped me during the period of my research in University hospital, Goettingen.

I would like to thank my lovely and beautiful wife Pari for her constant inspiration, moral and emotional support that gave me the strength and determination to complete this work. Last but not the least; words are insufficient to express my thanks to my parents, sister Nidhi and brother Sachin for all their love, encouragement and blessings. 


\section{PUBLICATIONS}

1. Velpandian Thirumurthy, Mathur Rajani, Agarwal Nitin Kumar, Arora Brijesh, Kumar Lalit, Gupta Suresh Kumar. Development and validation of a simple HPLC method with UV detection for the analysis of imatinib from biological samples. $\mathbf{J}$ Chromatogr B Analyt Technol Biomed Life Sci. 2004 May 25;804(2):431-4.

2. Dihazi Hassan, Asif Abdul Rahman, Agarwal Nitin Kumar, Doncheva Yuliana, Mueller Gerhard A. Proteomics analysis of cellular response to osmotic stress in thick ascending limb of henle's loop (TALH) cells. Mol Cell Proteomics. 2005 Oct;4(10):1445-1458.

3. Agarwal Nitin Kumar, Mueller Gerhard Anton, Mueller Claudia Anton, Streich Jan-Henrick, Abdul Rahman Asif, Hassan Dihazi. Methotrexate alters proteasome subunits and induces the endoplasmic reticulum chaperones in acute promyelocytic leukaemia cells. (Submitted) 


\section{ABSTRACTS}

1. Agarwal NK, Velpandiant T, Kumar A, Kotwal PP, Gupta SK. Postmarketing surveillance of newer COX 2 inhibitors: special reference to instant release and conventional formulations of nimesulide. Indian Journal of Pharmacology 2003; 35:131.

2. Agarwal NK, Mueller GA, Dihazi H. Expression changes of multi drug resistance genes MDR1 and MRP1 in renal carcinoma cells after methotrexate treatment. European Journal of Physiology 2005;449 supp 1:S99.

3. Agarwal NK, Asif AR, Mueller GA, Dihazi H. Proteomic analysis reveals methotrexate resistance due to downregulation of unfolded protein response and activation of antioxidant enzymes activity in renal cell carcinomas. Journal of American Society of Nephrology 2005; 16:156A.

4. Dihazi H, Agarwal NK, Mueller GA. Proteomics profiling of cellular responses to osmotic stress in renal epithelial cells; modulation of the cytoskeleton and of stress proteins of the endoplasmatic reticulum. Journal of American Society of Nephrology 2005; 16:153A.

5. Dihazi H, Agarwal NK, Mueller GA. Proteomics mapping of the role of endoplasmic reticulum stress proteins in osmotic stress resistance in TALH-cells. Journal of American Society of Nephrology 2006; 17:434A. 
6. Dihazi H, Agarwal NK, Mueller GA. Functional proteomics reveal involvement of endoplasmic reticulum stress pathway in the proliferation of renal interstitial fibrosis. Journal of American Society of Nephrology 2006;17:434A.

7. Dihazi H, Agarwal NK, Mueller GA. Gerhard A. Mueller Functional proteomics reveal involvement of endoplasmic reticulum stress pathway in the proliferation of renal interstitial fibrosis. Molecular \& Cellular Proteomics 2006;5:Supplement 10.

8. Dihazi H, Agarwal NK, Mueller GA. Proteomics mapping of the role of endoplasmic reticulum stress proteins in osmotic stress resistance in TALH-cells. Molecular \& Cellular Proteomics 2006;5:Supplement 10. 


\section{PRESENTATIONS}

1. Agarwal NK, Mueller GA, Dihazi H. Expression changes of multi drug resistance genes MDR1 and MRP1 in renal carcinoma cells after methotrexate treatment. European Journal of Physiology 2005;449 supp 1:S99.

Poster presented at $84^{\text {th }}$ Congress of the Deutsche Physiologische Gesellschaft held on March 06-09, 2005, Goettingen, Germany.

2. Agarwal NK, Asif AR, Mueller GA, Dihazi H. Proteomic analysis reveals methotrexate resistance due to downregulation of unfolded protein response and activation of antioxidant enzymes activity in renal cell carcinomas. Journal of American Society of Nephrology 2005;16:156A.

Poster presented at American society of Nephrology, Renal Week 2005 held on November 8-13, 2005, Philadelphia, USA.

3. Agarwal NK, Dihazi H, Mueller GA. Der Einsatz von Pharma-Proteomics für die Untersuchung der Zytotoxizität und Medikamentenresistenz bei malignen Erkrankungen.

Oral presentation at 10.IGLD und INSTAND e.V.(Institut für Standardisierung und Dokumentation im medizinischen Laboratorium) Jahrestagung und Workshops, held on March 30-31, 2006, Göttingen, Germany. 


\section{CURRICULUM VITAE}

Last Name:

First Name:

Date of Birth:

Place of Birth:

Citizenship:

Education:

1996-2000:

2001-2003:

2004-2007:
Agarwal

Nitin Kumar

$05^{\text {th }}$ November; 1975

Bareilly, Uttar Pradesh, India

Indian

Bachelor in Pharmacy (Pharmaceutical Sciences) MJP Rohilkhand University Bareilly, Uttar Pradesh, India

Master in Science (Pharmacological Sciences)

All India Institute of Medical Sciences, New Delhi, India

Doctorate (Biological Sciences)

Georg-August-Universitat Goettingen, Germany Member of DFG funded Graduiertenkolleg 335, entitled; Cellular and molecular biology of the internal organ

Thesis title: Proteome-wide identification of new molecular targets affected by methotrexate in acute promyelocytic leukaemia cell line. 